\title{
A global analysis of deforestation due to biofuel development
}

Yan Gao

Margaret Skutsch

Omar Masera

Pablo Pacheco

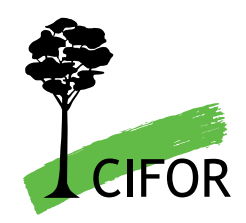



Working Paper 68

\title{
A global analysis of deforestation due to biofuel development
}

\author{
Yan Gao \\ Margaret Skutsch \\ Omar Masera \\ Centre for Ecosystem Research and Center for Research on Environmental Geography, UNAM \\ Pablo Pacheco \\ Center for International Forestry Research (CIFOR)
}


Working Paper 68

(C) 2011 Center for International Forestry Research

All rights reserved

Cover photo: Instituto de Pesquisa Ambiental da Amazonia, @ Daniel Nepstad

Caption: Soybean cultivation in Mato Grosso, Brazil

Gao, Y., Skutsch, M., Masera, O and Pacheco, P. 2011 A global analysis of deforestation due to biofuel development. Working Paper 68. CIFOR, Bogor, Indonesia

This paper has been produced with the financial assistance of the European Union, under a project titled, 'Bioenergy, sustainability and trade-offs: Can we avoid deforestation while promoting bioenergy?' The objective of the project is to contribute to sustainable bioenergy development that benefits local people in developing countries, minimises negative impacts on local environments and rural livelihoods, and contributes to global climate change mitigation. The project will achieve this by producing and communicating policy relevant analyses that can inform government, corporate and civil society decision-making related to bioenergy development and its effects on forests and livelihoods. The project is managed by CIFOR and implemented in collaboration with the Council on Scientific and Industrial Research (South Africa), Joanneum Research (Austria), the Universidad Nacional Autónoma de México and the Stockholm Environment Institute. The views expressed herein can in no way be taken to reflect the official opinion of the European Union.

\section{CIFOR}

Jl. CIFOR, Situ Gede

Bogor Barat 16115

Indonesia

$\mathrm{T}+62(251) 8622-622$

$\mathrm{F}+62(251) 8622-100$

E cifor@cgiar.org

\section{www.cifor.org}

Any views expressed in this publication are those of the authors. They do not necessarily represent the views of CIFOR, the authors' institutions or the financial sponsors of this publication. 


\section{Table of contents}

$\begin{array}{lll}\text { Abbreviations } & \mathbf{v}\end{array}$

$\begin{array}{lll}\text { Abstract } & \text { vi }\end{array}$

Acknowledgements $\quad$ vii

Executive summary

1 Introduction 1

2 General characteristics and use of biofuels $\quad 3$

2.1 Characteristics of bioethanol and biodiesel feedstocks 3

2.2 Use of biofuels 3

2.3 Synthesis 5

3 Methodological challenges $\quad \mathbf{6}$

3.1 Challenges related to measuring deforestation at the global scale 6

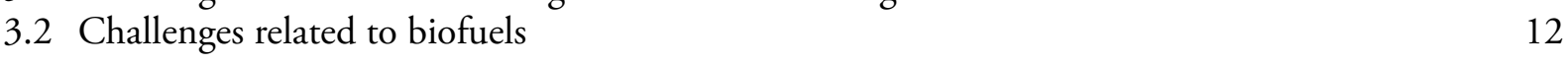

4 Identification of the direct deforestation caused by biofuels $\quad 15$

4.1 Main deforestation hotspots at the global level $\quad 15$

4.2 Main biofuel hotspots at the global level 16

4.3 Matching deforestation hotspots and biofuel hotspots at the global level 19

$\begin{array}{ll}4.4 \text { Synthesis } & 20\end{array}$

5 Identification of the indirect deforestation caused by biofuel development 22

5.1 Concepts and approaches to take iLUC into account 22

5.2 Preliminary findings of the impact of indirect land use change 23

5.3 Synthesis 24

6 Insights from the selected hotspots on biofuel development and deforestation 26

$\begin{array}{ll}6.1 \text { Synthesis } & 28\end{array}$

7 Deforestation and second generation biofuels: Future challenges and opportunities 29

8 Conclusions and issues for further study $\quad 30$

$\begin{array}{ll}\text { References } & 32\end{array}$

Appendices $\quad 39$

1 Characteristics and global suitability maps of the main biofuel feedstocks 39

2 World biofuel plants for selected developing countries by country 49

3 Additional information on selected biofuel feedstocks 56

4 Visited websites for biofuel and feedstocks information $\quad 58$

5 Selected hotspots on biofuel development and deforestation in tropical countries $\quad 60$ 


\section{List of figures and tables}

\section{Figures}

1 Global production of bioethanol for use as fuel (2000-2007) 4

2 Global production of biodiesel (2000-2007) 5

3 Global map of annual deforestation rate for the period 2000-2005 7

4 Four deforestation case studies, from 2000 to $2006 \quad 10$

5 Global deforestation map (2001-2005) generated using MOD44A data (Carroll et al. 2006) 16

6 Deforestation 2001-2005 (yellow) in Mato Grosso, Brazil 17

7 Deforestation detected in northern Sumatra, Indonesia during 2001-2005 $\begin{array}{ll}\text { presented on Google Earth image; yellow plots indicate deforestation } & 18\end{array}$

8 A preliminary map showing states or regions in which established global biofuel $\begin{array}{ll}\text { hotspots are located } & 20\end{array}$

9 A simple illustration of indirect deforestation $\quad 22$

10 Direct (A) and indirect (B) land use change in Brazil due to the expansion of soybean and sugarcane production to meet the country's present biofuel targets for $2020 \quad 24$

\section{Tables}

1 Production of bioethanol for fuel in the main production countries and worldwide (2007)

2 Global biodiesel production in selected production countries and worldwide (figures for 2007)

3 Tropical forest areas 8

4 Tropical forest change rate 8

5 Remote sensing images and their application in deforestation detection 9

6 Established biofuel hotspots $\quad 16$

7 Examples of small-scale emerging biofuel hotspots: Biodiesel from jatropha 19

8 Selected biofuel hotspots 26 


\section{Abbreviations}

$\begin{array}{ll}\text { APROSOJA } & \text { Associacáo dos Produtores de Soja do Estado de Mato Grosso } \\ \text { Asocaña } & \text { Asociación de cultivadores de caña de azúcar } \\ \text { ASTER } & \text { Advanced spaceborne thermal emission and reflection radiometer } \\ \text { AVHRR } & \text { Advanced very high resolution radiometer } \\ \text { CIFOR } & \text { Center for International Forestry Research } \\ \text { CPO } & \text { Crude palm oil } \\ \text { DNP } & \text { Departamento Nacional de Planeación (Colombia) } \\ \text { FAO } & \text { Food and Agricultural Organisation of the United Nations } \\ \text { FAOSTAT } & \text { Statistical Databases of the Food and Agricultural Organisation of the United Nations } \\ \text { FBOMS } & \text { Brazilian Forum of NGOs and Social Movements for the Environment and Development } \\ \text { FFB } & \text { Fresh fruit bunches } \\ \text { GEXSI } & \text { Global Exchange for Social Investment } \\ \text { GHG } & \text { Greenhouse gas } \\ \text { GIS } & \text { Geographical information system } \\ \text { GLCF } & \text { Global Land Cover Facility } \\ \text { Ha } & \text { Hectares } \\ \text { IBGE } & \text { Brazilian Institute of Geography and Statistics } \\ \text { LUC } & \text { Land use change } \\ \text { MAPA } & \text { Brazilian Ministry of Agriculture } \\ \text { MODIS } & \text { Moderate resolution imaging spectrometer } \\ \text { RSB } & \text { Roundtable on Sustainable Biofuels } \\ \text { RSS } & \text { Roundtable on Sustainable Soy } \\ \text { RSPO } & \text { Roundtable on Sustainable Palm Oil } \\ \text { SDSU } & \text { South Dakota State University } \\ \text { SI } & \text { Suitability Index } \\ \text { UNFCCC } & \text { United Nations Framework Convention on Climate Change } \\ \text { UNICA } & \text { Brazilian Sugarcane Industry Association } \\ \text { WRI } & \text { World Resources Institute } \\ \text { WWF } & \text { World Wide Fund for Nature } \\ \text { VCC } & \text { Vegetation cover conversion }\end{array}$




\section{Abstract}

The relationship between biofuel development and tropical deforestation is complex. It is difficult to detect direct links and to quantify these at the global level, due to limited data availability. These limitations include: the lack of time series data on deforestation at sufficient resolution on the global scale; the lack of information on the geographical location of biofuel cultivation areas; much of the deforestation related to biofuel cultivation being indirect through displacement of other agriculture; much of the biofuel cultivation being very recent; and, that many biofuel feedstocks are multipurpose (biofuels often represent only a small proportion of larger food and fodder production systems). Combined, these difficulties make it impossible to quantify the relationship between biofuel production and deforestation and to map it at the global level. Indirect land use change (iLUC) is of particular concern, as it can take effect in neighbouring regions or across the globe and is likely to become increasingly important as biofuel production increases. Indirect effects of biofuel production are likely to increase; although several studies have been carried out, no estimation method has yet been accepted. The rate of biofuel expansion will depend on many other factors, including land availability, enabling national government policies and foreign direct investment, as well as policy at an international level.

This report reviews the methodological difficulties in estimating the relationship between biofuel and deforestation in detail. It considers both the wellestablished biofuel feedstocks such as sugarcane for ethanol (in Brazil and Argentina) and palm oil for diesel (in Malaysia and Indonesia), and the emergent feedstocks such as jatropha, which is expanding in sub-Saharan Africa, India and Latin America. 


\section{Acknowledgements}

We thank our project partners for providing the biofuel 'hotspots' information for Brazil, Colombia, Ghana, Indonesia and Malaysia. Thanks also go to Antonio Navarrete for his advice on GIS techniques and to Enrique Riegelhaupt for his detailed comments.

We gratefully acknowledge contributions by Rubeta Andrani and George Schoneveld of CIFOR, and Robert Bailis and Jennifer Baka of Yale University who contributed to the completion of case studies for this report. 


\section{Executive summary}

Liquid biofuels have been produced on a commercial scale for many years, although political decisions made mainly in Europe and the United States have induced a sharp increase in demand. Furthermore, growing attention to rising greenhouse gas emissions (GHG) and global warming, combined with unstable and surging petroleum prices, are factors promoting biofuels as energy alternatives in the transportation sector. While sustainably produced biofuels have the potential to foster rural local development and to replace fossil fuels, their envisaged large scale and fast expansion has been contested on various fronts, including concerns about food security, impacts on small scale farmers, equity, increased competition for water, local pollution, and increased deforestation. The latter concern is in part related to the additional GHG emissions from forest clearing, broader concerns about the loss of natural heritage and biodiversity, and the loss of environmental and other services and goods that forests provide to local communities.

This report examines whether the recent increase in biofuel feedstock production is resulting in increased deforestation rates and magnitudes within tropical regions. It reviews several methodological challenges for undertaking this analysis, and presents a set of preliminary findings. The analysis is focused on three regions from a global perspective: Latin America, southeast Asia, and sub-Saharan Africa. The report deals only with agriculture-based feedstocks such as sugarcane, soya, palm oil and jatropha, known also as first generation biofuels, because second generation biofuels from wood or other lignocelullosic materials have not yet been produced on a commercial scale. The analysis centres on the years since 2000 due to the marked increase in biofuel production since then.

The report is based on a review of available literature and global databases that to different degrees deal with the interplay between deforestation and biofuel production. It uses the global deforestation assessment produced by the Maryland University for 2001-2005, and analyses visually the spatial relationship between the global deforestation data and global biofuel hotspots data obtained from the project partners' field surveys and contributions. Finally, to overcome the limitations of analysis performed at the global level, case studies are provided to facilitate a deeper understanding of the links between deforestation and biofuel production. The cases in this report have been selected and documented with the help of project partners in the different regions.

\section{Main findings}

1. The relationship between biofuel production and deforestation is very complex and thus difficult to quantify, particularly when assessed at the global level. Several factors contribute to this complexity. First, the establishment of biofuel feedstocks on forest land may lead to direct forest conversion, or it can lead indirectly to deforestation through the displacement of other crops/pasture into forestland. This latter effect may involve different regions within one country or even the world at large. Second, measuring both deforestation and biofuel production accurately is difficult due to the lack of standard definitions and the lack of updated datasets with sufficient spatial resolution and global coverage that include at least two time periods. Third, many feedstocks used for biofuel production are multipurpose since they are produced for both food/fodder and fuels, thus decisions on how much feedstock is devoted to any use varies seasonally; moreover these decisions are not made by cultivators but by dealers. For some feedstocks such as soya, the location of the biofuel plants and the plantations themselves is poorly correlated. Finally, when feedstocks have several economic end uses (for example soya, from which the cake is used as animal feed and the oil both as a food product and a biodiesel), the deforestation burden can be allocated in different ways.

2. It is not possible to obtain a reliable quantitative estimate of the global impact of biofuel 
development on direct deforestation. This is because no global deforestation data and global biofuel feedstock plantation data are available of sufficient resolution. Estimates can, however, be made for particular areas, on the basis of case studies. The report examines hotspots or landscapes where biofuel development has been linked to direct land use change (LUC) in Latin America, SE Asia and sub-Saharan Africa. A preliminary rough analysis, using the ratio of biofuel production to total oil production in 2009 , shows that biodiesel from oil palm may have been responsible for up to $2.8 \%$ and $6.5 \%$ of direct deforestation in Indonesia and Malaysia, respectively, while biodiesel from soybean in the Brazilian state of Mato Grosso may have been responsible for up to $5.9 \%$ of the direct annual deforestation over the last few years. The direct deforestation resulting from sugar-based ethanol in Brazil and Colombia appears to be negligible.

3. Preliminary findings in the literature on indirect LUC analysis indicate that it seems to be significant for many feedstocks and that its significance may grow in the future, particularly if biofuel feedstocks expand quickly on a large scale. The existing approaches to quantify iLUC rely on very complex modelling with varying assumptions and contrasting results. They have been used so far to examine the potential impact of future biofuel expansion plans in Europe, the United States and Brazil. However, most iLUC models are econometric, and do not indicate the specific spatial distribution of deforestation effects.

4. The relationship between biofuels and deforestation is being shaped by each country's political and institutional frameworks and socioeconomic settings. Producer countries with defined clear incentives and targets to stimulate biofuel production, either for domestic or foreign markets, have tended to expand their production capacity more rapidly. Yet the impacts on land use and forest cover change depend on a wider set of conditions strongly linked to the agricultural sector's performance; the impacts depend on, for example, the amount of land available for feedstock production, the comparative advantages of biofuel crops versus other food crops, the technologies and financial capital for agricultural production to which landholders have access, and the existing land use regulations, as well as the technical capacity of state agencies to enforce such regulations in practice.

5. The impacts of biofuels on deforestation depend greatly on the particular feedstock used. Preliminary findings indicate that, at least in Latin America, sugarcane is generally expanding on lands cleared for agriculture a long time ago; it mainly replaced other field crops. Thus, expanded production of ethanol from sugarcane is unlikely to cause direct deforestation, although it may cause indirect land use change by displacing crops or livestock into forests or grasslands. This indirect land use dynamic may also be influenced by other factors such as rising food prices or growing demand, or specific incentives promoting food production. On the other hand, soya is in general a pioneer crop, which is frequently produced on the agricultural frontier in forestlands cleared for this purpose or in areas cleared for pasture and beef production. Oil palm plantations (Malaysia, Indonesia) are often found in rainforest areas specifically cleared for this purpose, or in areas that had been cleared earlier but planted with rubber or coconut. Up to now, however, oil palm's expansion has reflected global demand for edible oil more than biofuels. Finally, jatropha has been promoted as a crop that uses 'wastelands', marginal lands or abandoned agricultural lands. However, in practice, dry secondary forests have often been affected, although jatropha's establishment is so recent that it is difficult to find evidence on this feedstock's impact on deforestation. However, expansion plans for jatropha plantations are very important, and preliminary findings from subSaharan Africa show that a portion of the lands acquired for establishing plantations are located within or surrounding closed forests, and were purchased without proper land use planning and sustainability criteria.

6. Seven major hotspots of biofuel and deforestation were reviewed in Latin America, sub-Saharan Africa, and SE Asia, and a sample of eight smaller but incipient hotspots in sub-Saharan Africa, 
Latin America and India. The review suggests that promoting a very rapid large scale expansion of biofuels will likely induce further direct and indirect deforestation. This is a result of the enormous economic pressure exerted by private firms to access land, combined with lack of adequate in-country institutions, regulations and capacity to enforce sustainability concerns. The current economic crisis, which has slowed down the biofuel 'boom', provides a good opportunity for national governments to reassess current targets and to build appropriate institutions at the local and international level to help cope with these concerns. Efforts such as the Roundtable on Sustainable Biofuels (RSB) are encouraging and should be promoted and reinforced.

7. New research is urgently needed on the potential impact of second generation lignocellulosic biofuels on deforestation. Initial studies suggest that these biofuels may have substantial impacts if short rotation plantations are established on former agricultural land. Also, the potential deforestation and forest degradation-induced effects of second generation biofuels due to the competition for fibre and fuel may be very significant if not properly addressed, particularly if organised production displaces fuelwood and charcoal production in developing countries' informal energy sectors.

8. More detailed research is needed to better understand the relationship between biofuel development and deforestation, and associated social and environmental impacts. This research needs to include both better spatial modelling of direct and indirect land use changes associated with biofuel production and an analysis of in-depth case studies that could illustrate representative situations. Detailed analysis in these case studies will allow higher spatial resolution satellite images to be used to derive detailed land use change maps, and to obtain more accurate information on feedstock plantation development and biofuel production facilities, all of which are essential to improve the present analysis. 


\section{Introduction}

Biofuels have been produced on a commercial scale for many years, but political decisions made mainly in Europe and the United States to increase biofuel use are inducing a sharp increase in demand. In addition, growing attention to rising GHG emissions and the resultant global warming, combined with unstable and surging petroleum prices, is pushing biofuel as an alternative to gasoline and diesel in the transportation sector. Nonetheless, plans for further massive increases in biofuel production to replace fossil fuels have been contested in various ways. Since biofuel production takes up some lands under agricultural production ${ }^{1}$, a major debate is underway concerning whether biofuel feedstock production will displace food and lead to increased food prices, and thus threaten food security, particularly for poor people in developing countries (WBGU 2008). Associated with this debate are growing concerns regarding whether an agricultural switch from food to fuel production will result in vulnerable small scale farmers losing access to their lands and thus reduce the distribution of land-based income generation.

Another controversial issue, which is this report's focus, is whether increasing biofuel feedstock production is resulting, or will result, in increased deforestation rates and reductions in forest area across different locations. The latter concern is to a large extent related to the additional carbon emissions that result from forest clearing, with impacts on climate change. It has to do with broader concerns linked to the loss of natural heritage and biodiversity, and a decrease in the environmental services and goods that forests provide to local populations. This report, which shares these latter concerns, seeks to explore the interactions taking place between biofuel feedstock production and deforestation.

1 Feedstock production for energy purposes currently represents $2.3 \%$ of land under agricultural production; however, with many national government mandates and volume targets in place, by 2030 up to $36 \%$ of the current arable land may be required for future bioenergy production. Scenarios show a very large variability (from 118 to 508 million ha) depending on overall assumptions regarding increases in crop productivity, type and quality of land accessible and other variables (Ravindranath et al. 2009).
An important debate is going on in the popular media on the links between biofuel development and deforestation. Two contradicting perspectives dominate the discussion. On the one side, environmental perspectives including the Global Forest Coalition, the Dutch NGO Fern, Greenpeace and conservation scientists, argue that biofuels will increase GHG emissions ${ }^{2}$, destroy tropical forests ${ }^{3}$, cause conflicts with local communities ${ }^{4}$ and undermine food security (Fearnside 2001; Biofuel Watch Centre 2008; Demirbas 2009; Ribeiro and Matavel 2009). On the other side, biofuel proponents argue that in addition to reducing the use of fossil fuels and emissions and providing jobs and income opportunities, biofuels are grown almost entirely on agricultural or pastoral land, and thus do not involve deforestation (Goldemberg 2007; World Growth (passim)). The divide between these two viewpoints is large, but it is important that they are juxtaposed and discussed.

Brazil, being the largest biofuel producer among developing countries, has been at the centre of the biofuel-deforestation debate. In a simplified perspective, some argue that sugarcane expansion in the country's south is leading to growing expansion of soybean in the centre west which in turn is displacing cattle herds further into the Amazon region, thus inducing growing deforestation (Nepstad et al. 2008). In contrast, others contend that this argument lacks evidence and that bioethanol production does not lead to deforestation since more than $85 \%$ of the planted sugarcane in Brazil is located more than 2000 kilometres from the Amazon forest (Sawaya and Nappo 2009). Contradictory arguments also prevail for soybean expansion in Mato Grosso, Brazil. Branford and Freris (2000) conclude that the expansion of soya plantations is a cause of deforestation resulting in various social problems.

\footnotetext{
2 Source URL: http://www.nytimes.com/2008/02/08/science/ earth/08wbiofuels.html.

3 Source URL: http://www.globalforestcoalition.org/paginas/ view/11.

4 Source URL: http://www.thejakartapost.com/ news/2009/02/04/ri-biofuel-development-an-asian-dilemma. html.
} 
In contrast, others argue that the Brazilian soya industry has little to do with forest clearing, and has an important role in promoting regional economic development (Brown 2004; Goldemberg 2007; Goldemberg and Guardabassi 2009).

The debate between the 'pro biofuel' and the 'anti biofuel' camps exists also in the palm oil sector, as evidenced by the report 'Palm Oil, the Sustainable Oil' circulated by a support group for the industry (World Growth 2009). This latter report categorically denies that palm oil causes deforestation or GHG emissions. However, the report's integrity has been heavily criticised as it is based on highly selective or simply biased use of data and facts (Laurance $e t$ al. 2010). Other reports argue that the expansion of palm oil plantations has indeed caused deforestation in tropical countries, especially Malaysia and Indonesia (Milieudefensie et al. 2008).

It is noteworthy that more balanced views have also emerged regarding the relationships between biofuel development, deforestation and forest degradation, particularly in the more academic literature. These nuanced views analyse both the pros and cons of biofuel development, suggesting that-within reasonable limits_expansion of biofuel feedstocks might be possible while protecting forest resources (Gibbs et al. 2008; Demirbas 2009). In addition, the Roundtable on Sustainable Biofuels (RSB), the Roundtable on Sustainable Palm Oil (RSPO) and the Roundtable on Sustainable Soy (RSS) have emerged as formal initiatives involving producers, industry, government officials and experts, to actively seek ways to promote responsible and sustainable biofuel production.
In order to analyse the spatial relationship between deforestation and biofuel development, we conducted a comprehensive review of both global deforestation data and biofuel production areas in Latin America, SE Asia, and sub-Saharan Africa. To overcome some gaps in assessing these interactions at a global level, we complemented this information with a review of regional and local biofuel hotspots that allowed a more in-depth analysis of both the characteristics of biofuel production and the detailed dynamics of biofuel and deforestation; this may help to draw more general conclusions.

This report is organised in eight sections, including this introduction. The second section discusses the main characteristics of biofuels and their associated feedstocks. The third section examines in detail the methodological challenges involved in making explicit spatial correlations between biofuel development and deforestation. The fourth section explores the direct links between the locations of deforestation hotspots to the main locations where biofuel production and/or fast expansion is taking place in practice. The fifth section talks about the indirect land use change effects of biofuel development. The sixth section offers a discussion about the selected biofuel hotspots; detailed descriptions can be found in Appendix 5. The seventh section discusses briefly the future challenges and opportunities of the second generation biofuels. The final section provides the main conclusions based on this analysis. 


\section{General characteristics and use of biofuels}

The term 'biofuel', as used in this report, refers to liquid fuels derived from biological material, used mainly, though not exclusively, for transport (Dossche and Ozinga 2008). Ethanol and biodiesel are the two main liquid biofuel types. First generation biofuels refer to current mainstream fuels made from sugars, starches, animal fats or vegetable oils using conventional technology; second generation biofuels are usually made from lingocellulosic fibres such as wood and agricultural waste, using advanced technical processes; third generation biofuels refer to biodiesel from algae (Dossche and Ozinga 2008). In this report we use interchangeably 'biofuel development' and 'biofuel feedstocks development'.

\subsection{Characteristics of bioethanol and biodiesel feedstocks}

The main feedstocks for ethanol production are maize and sugarcane; the main feedstocks for biodiesel are soya, palm oil and rape seed. Their main characteristics and global suitability maps of these biofuel feedstocks are presented in Appendix 1. In addition, a large number of other crops are also produced on a small scale for biofuel production including jatropha, sunflower, sugar beet, sorghum and castor bean (Appendix 1). Second generation biofuels are hardly produced yet outside experimental sites (Sims et al. 2008). They are likely to use agricultural and forest residues, as well as natural forests as the feedstock source, and therefore potentially pose a greater threat to forests than more conventional feedstocks. A sustainable harvesting system could be established to reduce the impacts on forests, but this could then affect traditional fuel supplies such as firewood and charcoal.

\subsection{Use of biofuels}

The use of biofuel in the transport sector (land based) is still low in most countries with the exception of Brazil. In recent years, however, it has been expanding as a consequence of political decisions and targeted state promotion policies, for example through the use of blending norms (WBGU 2008).
Its role in aviation may in the future become important, but it is hard to predict what this sector's demand will be, as this will depend not only on the economics but also on whether it is promoted by national and international policies.

\subsubsection{Use of bioethanol}

Global bioethanol production in 2007 totalled 52 billion litres (WBGU 2008); output has thus trebled since 2000 (Figure 1). The largest bioethanol producers are Brazil and the USA (Table 1).

Table 1. Production of bioethanol for fuel in the main production countries and worldwide (2007)

\begin{tabular}{lcc}
\hline \multirow{2}{*}{ Country/region } & \multicolumn{1}{c}{ Production } \\
\cline { 2 - 3 } & Amount (billion litres) & Production (\%) \\
\hline United States & 26.5 & 51.0 \\
Brazil & 19.0 & 36.5 \\
European & 2.3 & 4.4 \\
Union & & \\
China & 1.8 & 3.5 \\
India & 0.4 & 0.8 \\
World & 52.0 & 100.0 \\
\hline
\end{tabular}

Source: WBGU (2008)

The bioethanol feedstocks differ from region to region: in the US bioethanol is produced mainly from maize, Brazil uses sugarcane and Europe uses, among other crops, sugar beet and wheat ${ }^{5}$ (WBGU 2008).

\subsubsection{Use of biodiesel}

Global biodiesel production in 2007 totalled 10.2 billion litres (Table 2), and the annual figure has increased more than tenfold since 2000 (WBGU 2008, Figure 2). As with bioethanol, biodiesel feedstocks differ from region to region: in Europe rapeseed is the chief crop grown and processed into

\footnotetext{
5 The sugar contained in the plants is fermented with the aid of yeast and enzymes to form bioethanol and $\mathrm{CO} 2$. It is then dehydrated in a multistage distillation process and brought to an ethanol content of $99.5 \%$. The energy content per litre of ethanol is only $65 \%$ that of fossil petrol, which means the quantity of bioethanol used by a vehicle will be around one and a half times the quantity of gasoline needed to travel the same distance (WBGU 2008).
} 


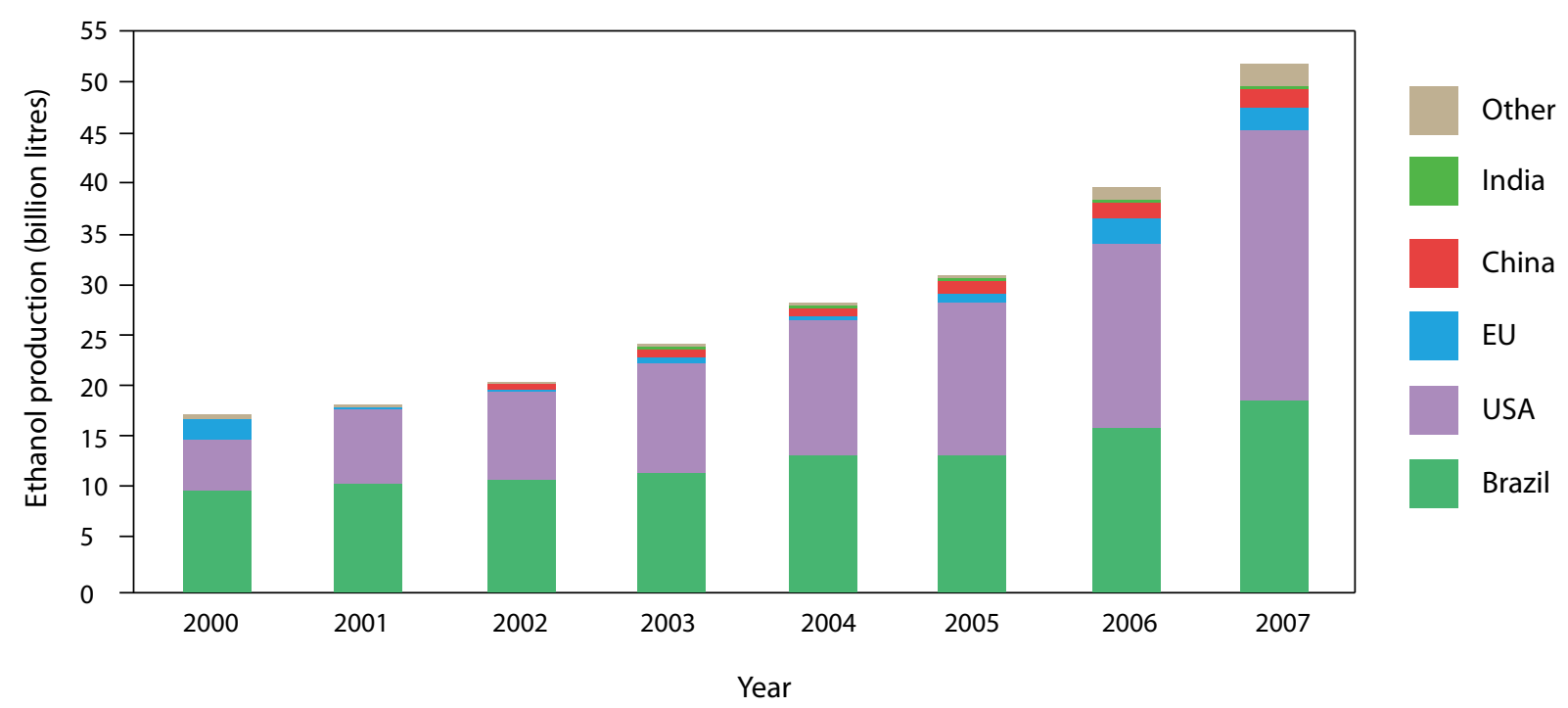

Figure 1. Global production of bioethanol for use as fuel (2000-2007)

Source: WBGU (2008)

biodiesel $^{6}$; palm oil is the main feedstock for biodiesel in Malaysia and Indonesia ${ }^{7}$; soya is being used increasingly in South America by countries such as Brazil and Argentina ${ }^{8}$.

Production of plant oils and fats for biodiesel totalled 9.5 million tonnes, of which 2.1 million tonnes came from soya (WBGU 2008). An analysis by Greenpeace showed that in Germany, 20\% of blended plant diesel is produced from soya oil (WBGU 2008).

The main biodiesel producer is the European Union, which accounts for $60 \%$ of the world market, in particular Germany and France (WI 2007). While global production has increased in recent years, it is currently declining partly as a result of current high raw material prices or changes in national tax concessions. In addition, the production capacity of some plants has been reduced, and some plants have closed completely (WBGU 2008).

6 Biodiesel is produced by esterification from plant oils, principally rapeseed, soya and palm oil (WBGU 2008). 7 Malaysia and Indonesia produce almost $90 \%$ of global palm oil, and most of it is exported as food. However, a varying proportion (depending on the market, which is very volatile) is converted into biofuel, and this may increase in the future (WBGU 2008).

8 In 2007/08 the largest soya-producing countries were the USA with 71 million tonnes, Brazil with 61 million tonnes and Argentina with 47 million tonnes (WBGU 2008)
Table 2. Global biodiesel production in selected production countries and worldwide (figures for 2007)

\begin{tabular}{lcc}
\hline \multirow{2}{*}{ Country/region } & \multicolumn{2}{l}{ Production } \\
\cline { 2 - 3 } & Amount (billion litres) & Production (\%) \\
\hline European Union & 6.1 & 59.9 \\
United States & 1.7 & 16.5 \\
Brazil & 0.2 & 2.2 \\
China & 0.1 & 1.1 \\
India & 0.05 & 0.4 \\
Malaysia & 0.3 & 3.2 \\
Indonesia & 0.4 & 4.0 \\
World & 10.2 & 100.0 \\
\hline
\end{tabular}

Source: WBGU (2008)

\subsubsection{Use of the second and third generation of biofuels}

Technologies for producing second generation (ligneous) and third generation (algae-based) biofuels are in development. They hold the promise of better fuel characteristics as well as higher yields and greenhouse gas reduction potential, leading to a more efficient use of the feedstocks. However, more complex production plants are needed, with higher investment costs. The third generation of biofuels is still in the basic research stage. It will be some years before the second and third generation biofuels are ready for the market (WBGU 2008). 


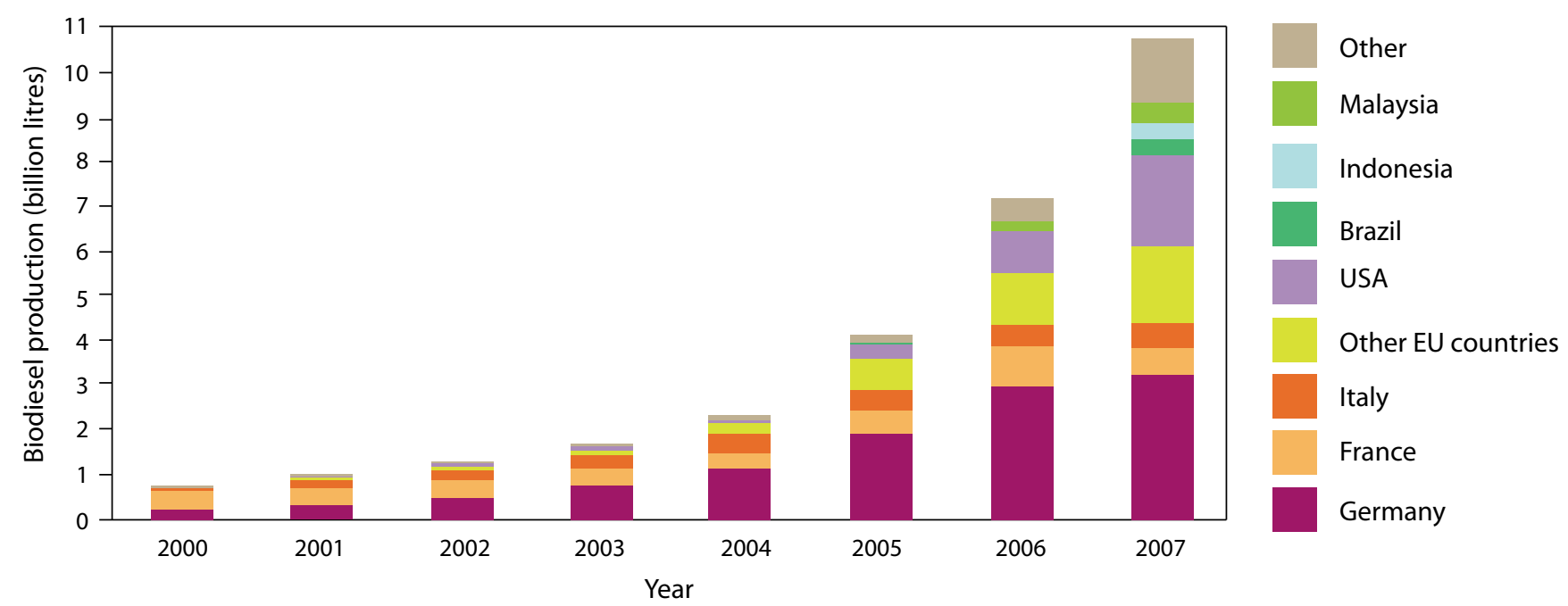

Figure 2. Global production of biodiesel (2000-2007)

Source: WBGU, cited in Future Bioenergy and Sustainable Land Use (2008)

\subsection{Synthesis}

Global ethanol production is dominated by two crops (sugarcane and corn) and global biodiesel production by soybean and oil palm. The number of producing as well as consuming countries is very limited at the moment, with the United States, Brazil and the European Union playing the dominant role in both aspects. Biofuel use in the transport sector is, however, beginning to expand rapidly as a consequence of political decisions and targeted state promotion policies. 


\section{Methodological challenges}

Assessing the implications of biofuel development on land use change, and specifically on deforestation, poses several methodological challenges. Four challenges are particularly relevant and will be addressed in this paper. The first relates to data availability and quality on recent deforestation, figures at the global level, biofuel data on the geographical location of feedstock plantations, and production levels. The second relates to the multipurpose nature of feedstocks since most are used for both food and fuel consumption (for example, soya, which is used for food or cattle feed, and biodiesel production). The third is linked to the land use implications of biofuel production on forest conversion since, on the one hand, biofuels can be grown on lands that support forests, thus leading directly to deforestation, and on the other hand, biofuels are also cultivated on croplands or pasture, with these land uses potentially then displaced into the forest, thus indirectly leading to forest clearance. The latter effect can occur either at the national or international scale. The fourth challenge is that deforestation is often caused by multiple drivers, only one of which is biofuel feedstock expansion.

Those challenges suggest that making spatial correlations between biofuel production and deforestation is a difficult task. This section examines first the problems related to data availability on magnitudes and rates of deforestation. Then it discusses difficulties identified in the literature when associating particular drivers with deforestation at the global level. We then turn to the even more problematic issue of data availability on biofuel production and examine the complexities derived from the multipurpose nature of feedstocks. Finally we examine two approaches used to match deforestation to biofuel production: a) direct land use changes due to biofuel development, through remote sensing techniques, and b) indirect land use change, through modelling.

\subsection{Challenges related to measuring deforestation at the global scale}

Deforestation is a complex process and getting reliable global estimates remains a challenge (Hansen et al. 2008; 2010; Grainger 2008). The main issues are related to the differences in definitions, poor reliability of the available global data, limited time series data for recent years, and restrictions in the spatial resolution of satellite images. Finally, some difficulty is involved in attributing deforestation dynamics to particular drivers.

\subsubsection{Poor reliability of deforestation data in global databases and lack of standard definitions about deforestation}

Deforestation as yet has no universally accepted definition, which makes it difficult to make comparative analyses across countries. The United Nations Framework Convention on Climate Change (UNFCCC) defines forest ${ }^{9}$ and deforestation ${ }^{10}$, such that deforestation is said to occur when the canopy cover of a forested area falls below a minimum threshold already selected by each country, in the range between $10-30 \%$, with some attendant height and area thresholds (Achard et al. 2007). Deforestation is thus essentially a change in land use and refers only to such changes that are due to human, not natural activities. The US Department of Agriculture Forest Service considers deforestation a non-temporary change of land use from forest to

9 According to the UNFCCC, 'forest' is a minimum area of land of $0.05-1.0$ hectares with tree crown cover (or equivalent stocking level) of more than $10-30 \%$ with trees with a potential to reach a minimum height of $2-5 \mathrm{~m}$ at maturity in situ. A forest may consist either of closed forest formations where trees of various stories and undergrowth cover a high proportion of ground or open forest. Under this definition, a forest can contain anything from $10-100 \%$ tree cover; it is only when cover falls below the minimum crown cover as designated by a given country that land is classified as non-forest. To date, most countries are defining forests with a minimum crown cover of $30 \%$.

10 The UNFCCC defines deforestation as the direct humaninduced conversion of forested land to non-forested land. 
another land use or depletion of forest crown cover to less than $10 \%$. Clear cuts (even with stump removal), if shortly followed by reforestation for forestry purposes, are not considered deforestation. The difficulty is therefore to distinguish those losses that are temporary and part of a sustainable cycle, from those that are permanent and really contributing to increased atmospheric carbon dioxide.

During the last 50 years, systematic country-bycountry information on the state and change of tropical forests has been produced exclusively by the United Nations Food and Agriculture Organisation (FAO) whose reports have been the main, and often the only, reference for discussion and analysis at regional and global level. While researchers have made frequent use of the FAO data, they have also pointed out its weaknesses, particularly its uneven quality and its inconsistent definitions across nations (e.g. Matthews and Grainger 2002; Marklund and Schöne 2006). The wealthier and larger countries have produced more reliable estimates based on analyses of field surveys or satellite imagery while smaller and poorer countries have relied on extrapolations from outdated surveys or other dubious estimation techniques (Rudel et al. 2005). Besides, scientists and conservationists have argued that the $\mathrm{FAO}$ provides too conservative an estimate of deforestation rates because, for example, it considers any area larger than 1 ha $(0.01$ square miles) with a minimum tree cover of $10 \%$ to be forested (FAO 2006).

In any case, FAO (2006) deforestation data are submitted by individual countries and they use different types of definitions, different data and different methods to estimate land cover and change, which makes comparison very difficult. Besides, since the data are reported by individual countries following their own procedures, they are difficult to verify (Jepma 1995; Stokstad 2001; Drigo et al. 2009). Many developing countries have very poor data, with almost no forest inventories and only analysis from remote sensing, which often uses different procedures and land classifications methods for different years (Matthews and Grainger 2002). Faulty interpretation of images has introduced errors (Zahabu 2008).

Moreover, FAO's data on forest cover and deforestation are reported in aggregate figures at the national level (Figure 3). Table 3 and Table 4 represent tropical forest areas and tropical deforestation rates, by each of the world tropical regions, based on FAO data (FAO 2006). According to this information, about an estimated 11.8 million ha per year were lost worldwide between 2000 and 2005; 80\% of total deforestation took place in tropical Africa and tropical America, and the global figures have remained almost constant

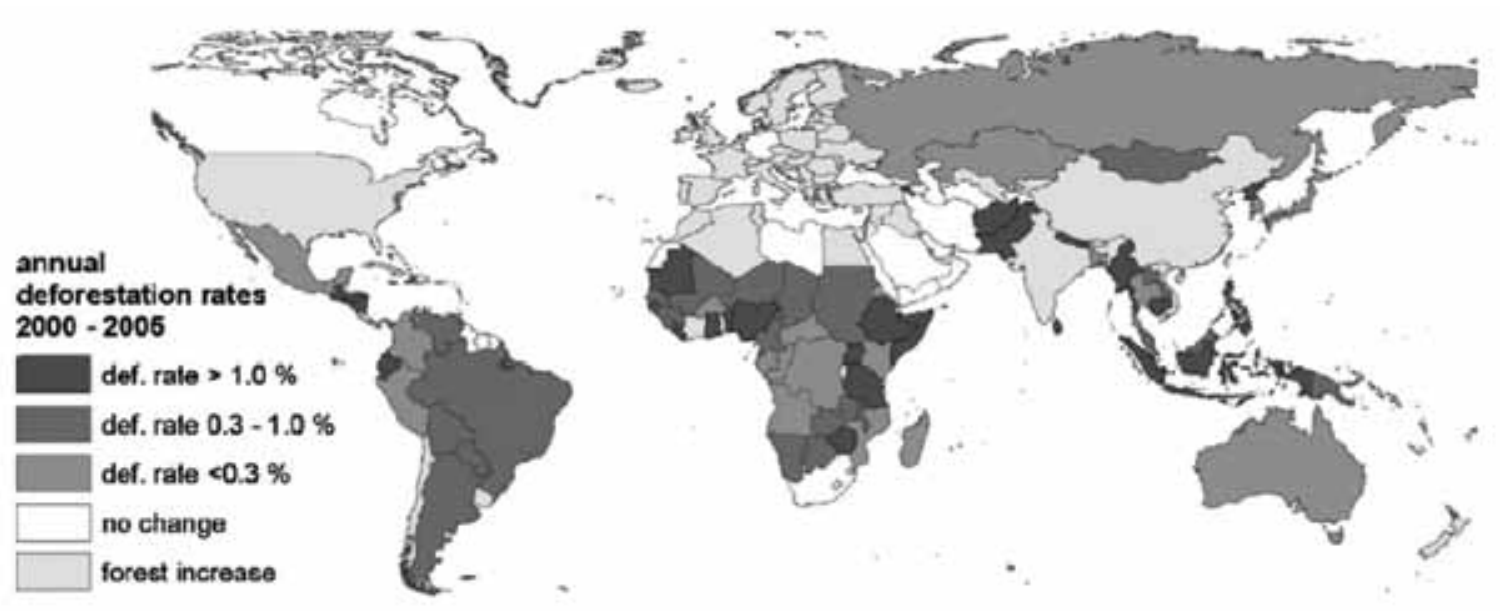

Figure 3. Global map of annual deforestation rate for the period 2000-2005

Source: Drigo et al. (2009) 
between 1990-2000 and 2000-2005. In fact, deforestation rates have increased within tropical Asia and Latin America while decreasing very slightly for sub-Saharan Africa. At least three countries with important biofuel production show large deforestation rates in this period: Brazil, Argentina, and Indonesia.

It is not possible from the FAO database to ascertain where in the country deforestation is occurring, which is critical in relating deforestation to biofuel production. The data (the most recent available in this form) is, moreover, out of date, and it is to be expected that changes have occurred in the last five years. In particular, deforestation rates in Brazil slowed during this period. The availability of a new FAO pantropical data set based on classified Landsat scenes provides a spatial view of what has occurred in the past. It has recently been utilised (Gibbs et al. 2010) to show that between 1980 and 2000, 55\% of new agricultural land came from intact forests and $28 \%$ from disturbed forests, but unfortunately these data do not throw light on the current period. Hansen et al. (2008) used a probability based sampling method to estimate gross forest clearance (i.e. not taking into account any regrowth or new plantation), and found, like Gibbs et al. 2010, that deforestation tends to be highly concentrated. The

Table 3. Tropical forest areas

\begin{tabular}{lccc}
\hline \multirow{3}{*}{ Tropical subregions } & \multicolumn{3}{c}{ Area } \\
& \multicolumn{3}{c}{$\mathbf{1 0 0 0 \text { ha }}$} \\
\cline { 2 - 4 } & $\mathbf{1 9 9 0}$ & $\mathbf{2 0 0 0}$ & \multicolumn{1}{c}{$\mathbf{2 0 0 5}$} \\
\hline Tropical Africa & 682698 & 638179 & 617679 \\
Tropical America & 941393 & 896866 & 873515 \\
Tropical Asia & 323156 & 297380 & 283126 \\
Tropical Oceania & 36891 & 35164 & 34268 \\
Tropical World & 1984138 & 1867589 & 1808588 \\
\hline
\end{tabular}

Source: adapted from Drigo et al. (2009) main hotspot areas identified include the Amazon basin and insular SE Asia (Indonesia and the Malaysian islands), and parts of the boreal forests of the northern hemisphere, which are not included in the scope of our analysis.

\subsubsection{Limited availability of global maps and images from which deforestation can be estimated.}

Before remote sensing techniques became widely available, field survey was the only way to obtain accurate, spatially explicit deforestation data. This is expensive, laborious, time consuming and, as noted above, many countries do not have the resources to do such forest inventories regularly and comprehensively and have therefore used a variety of estimation methods (hardly specialised) rather than field data. However, even though remote sensing has been commonly used in most countries for the last 20 years, this specialised data has not been systematically collated by the FAO.

Fortunately the increasing availability of remote sensing images and techniques facilitates the production of global deforestation maps, independent of national assessments. This requires firstly, that satellite images with appropriate spatial, spectral and temporal resolutions are selected. On the one hand, higher spatial resolution images cover smaller areas, with smaller spectral and temporal resolutions, and are expensive to obtain. On the other hand, lower spatial resolution images cover larger areas and have higher spectral and temporal resolutions. So for mapping deforestation at the global level, lower spatial resolutions are the better choice. MODIS (moderate resolution imaging spectrometer) data became available in 2000. MODIS images have mid-spatial resolution, high spectral resolution, cover large areas and are freely accessible.

Table 4. Tropical forest change rate

\begin{tabular}{|c|c|c|c|c|}
\hline \multirow[t]{2}{*}{ Tropical subregions } & \multicolumn{2}{|c|}{$\begin{array}{c}\text { Annual change rate } \\
\text { (1000 ha/year) }\end{array}$} & \multicolumn{2}{|c|}{$\begin{array}{c}\text { Annual change rate } \\
(\%)\end{array}$} \\
\hline & 1990-2000 & 2000-2005 & 1990-2000 & $2000-2005$ \\
\hline Tropical Africa & -4452 & -4100 & -0.65 & -0.64 \\
\hline Tropical America & -4453 & -4670 & -0.47 & -0.52 \\
\hline Tropical Asia & -2578 & -2851 & -0.80 & -0.96 \\
\hline Tropical Oceania & -173 & -179 & -0.47 & -0.51 \\
\hline Tropical World & -11655 & -11800 & -0.59 & -0.63 \\
\hline
\end{tabular}

Source: adapted from Drigo et al. (2009) 
The main implication of selecting images with a given resolution relates to the minimum area that can be identified as deforested. Table 5 lists and compares the main types of remote sensing images, their spatial resolutions and scene covers, the cost of purchase, etc. Here, spatial resolution indicates what detail can be seen: the higher the spatial resolution, the more detail the image shows. Scene cover indicates how much area each image covers. We have not included aerial photography in this analysis because of the enormous costs and time involved in obtaining and analysing such images at the global scale.
For studies at the global level, images with larger scene covers are preferred in order to reduce the labour and time involved in data collection and processing. However, since the spatial resolution is low, the details of objects observed on the ground are less visible than in higher spatial resolution images. Although this tradeoff must be considered, for reasons of cost, deforestation mapping at the global level is generally carried out using relatively coarse spatial resolution images. Using MODIS images, with a spatial resolution of $250 \mathrm{~m}$ (MOD09 data), the minimum area that can be mapped is 30 ha. Thus,

Table 5. Remote sensing images and their application in deforestation detection

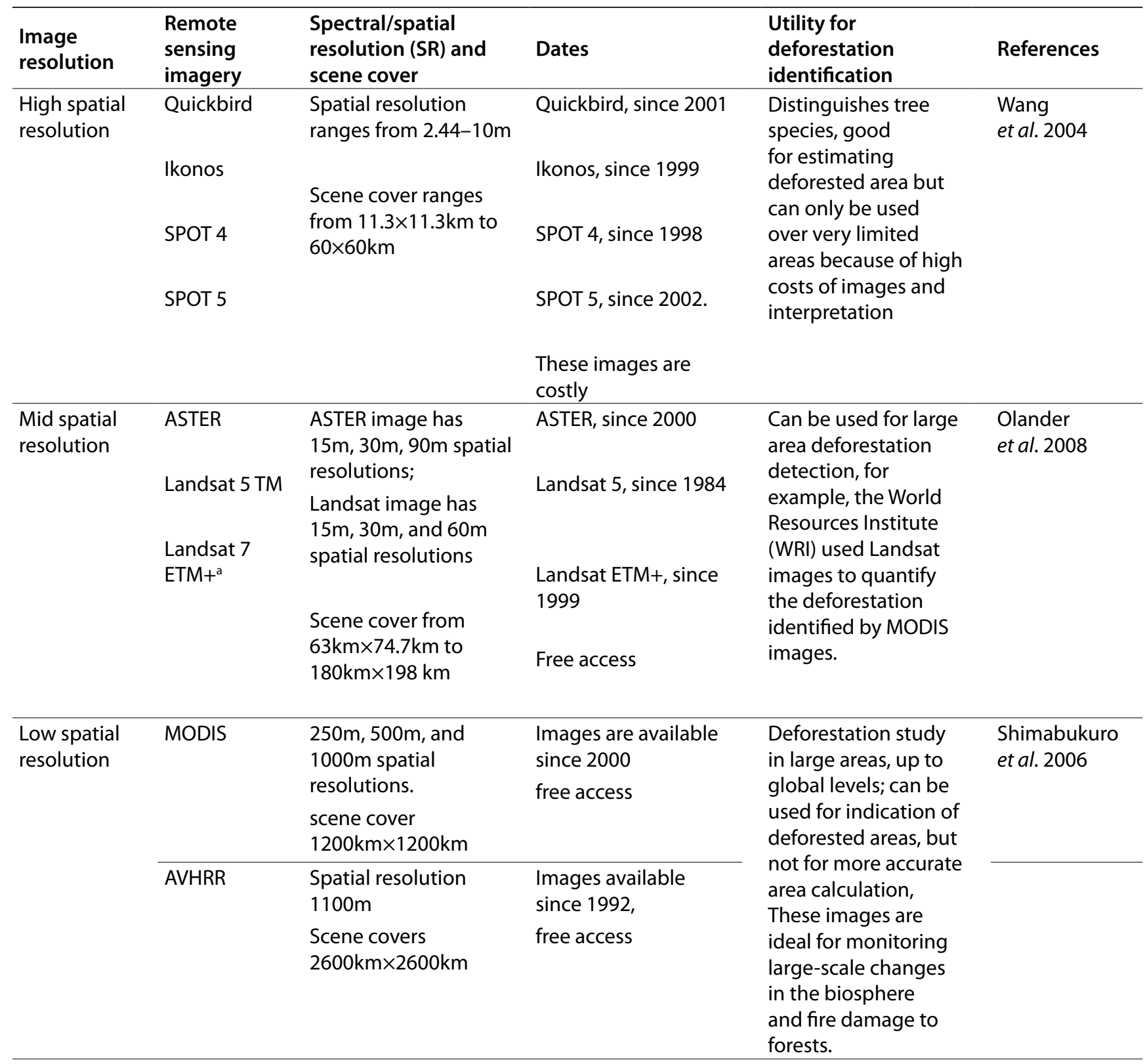

a Since May 2003, there has been a failure in the scene corrector. 
global deforestation data mapped with MODIS images can only be used to show the location of deforestation but without accurate quantification of the area involved. Clearly, different resolutions can be used for different tasks: very high resolution images are perhaps most useful for zooming in and sampling for monitoring purposes rather than producing universal data.

Interesting products in this respect are the global tree cover per cent data and the tree cover change maps based on MODIS satellite data (Hansen et al. 2005). The Global Land Cover Facility at the University of Maryland mapped global deforestation from 2001 to 2005. The data and resulting map can be freely accessed at http://glcf.umiacs.umd.edu/index. shtml. The World Resources Institute (WRI) has also started a deforestation mapping exercise and has so far mapped deforestation in four tropical locations: Brazil, Cambodia, Central Africa and Indonesia. The information is available from http://www.wri.org/ publication/painting-the-global-picture-of-tree-coverchange, and gives tree cover change from 2000 to 2006 (see Figure 4).

The particular advantage of the WRI approach is that MODIS images $(500 \mathrm{~m})$ have been used to identify the locations of deforested areas and these locations have been zoomed in on using Landsat images, which have higher spatial resolution, to allow the calculation of deforestation areas in hectares. This method has also been adopted by the Indonesian Government in a project called Forest Monitoring and Assessment System (FOMAS) in which WRI, South Dakota State University (SDSU) and others have collaborated. While this data is very useful for the four countries mentioned, unfortunately it does not constitute a globally specialised data set. For this reason, the map produced by the University of Maryland has been used in our analysis (see section 4). The deforestation data mapped with MODIS images indicate where the deforestation has happened. Based on this information, more detailed studies can be carried out in each particular area to obtain more specific information such as estimated biomass loss and deforestation drivers. Due to the coarse resolution of MODIS imagery, not all deforestation types can be monitored. For example, selective logging by which one to four trees are logged per ha is difficult to detect with MODIS imagery. For the same reason, it is not possible to estimate how much forest has been lost using MODIS imagery. To date, no statistics have resulted from these programs that may be considered as an alternative to those produced by the FAO.

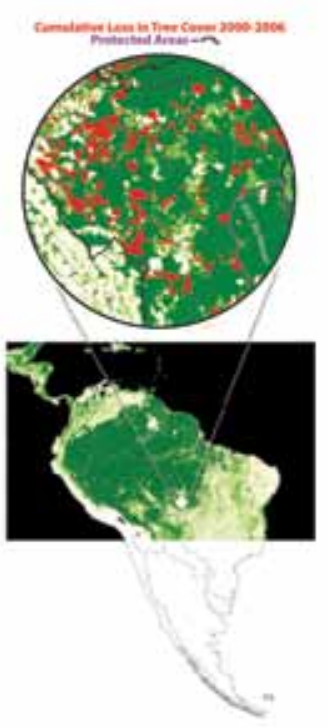

Brazil
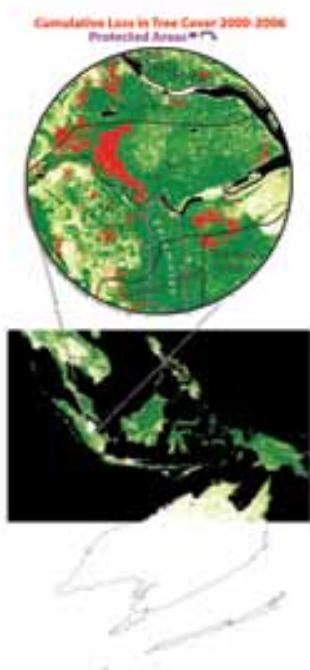

Indonesia
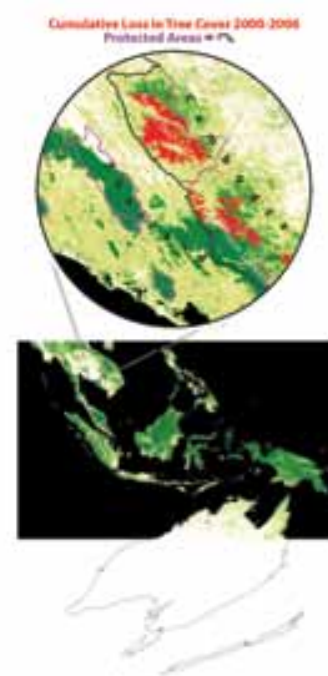

Cambodia

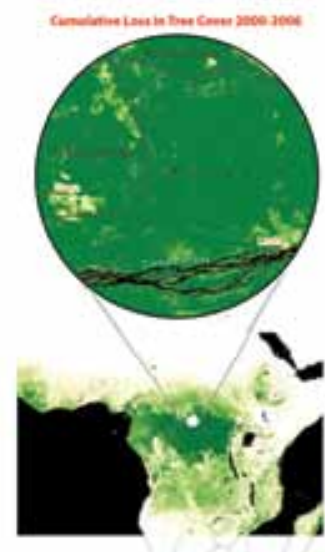

Central Africa

Figure 4. Four deforestation case studies, from 2000 to 2006

Source: URL: http://www.wri.org/publication/painting-the-global-picture-of-tree-cover-change 
Besides the data selection, the study of land cover changes over large and diverse landscapes is not the simple task that one may think. Except for particularly simple conditions such as, for instance, the large and squared clearings common in the Brazilian Amazon, land cover changes are usually small, elusive events whose reliable detection requires evaluation processes far more rigorous than normally accepted for conventional mapping purposes. The comparison of two land cover maps independently produced over the same areas will inevitably identify differences that include true changes as well as other differences resulting from the different interpretation procedures adopted in each mapping process (Drigo et al. 2009).

\subsubsection{Difficulties in numerically and spatially explicitly ascribing deforestation to particular drivers}

Deforestation drivers are very diverse and vary by countries and states. A number of important studies have attempted to generalise and pull together large numbers of local studies (for example, Geist and Lambin 2002; Angelsen and Kaimowitz 1999). This work is hampered, however, by the fact that most information on drivers is not quantitative, so that few direct quantitative correlations can be made linking certain quantities of deforestation to particular activities. Angelsen and Kaimowitz (1999) reviewed 140 economic models analysing the causes of tropical deforestation. They found that, when looking at proximate causes, deforestation is often associated with the presence of more roads, higher agricultural prices, lower wages, and a shortage of off-farm employment. Also, they considered it likely that policy reforms associated with economic liberalisation and related adjustment increase the pressure on forests. They pointed out, however, that many research studies have adopted poor methodology and low quality data, which makes the drawing of clear conclusions about the role of macroeconomic factors difficult.

Geist and Lambin (2002) analysed 152 case studies to find out whether the causes and underlying driving forces of tropical deforestation fall into any patterns. The reviewed studies range from community level to a multiprovince area, mostly covering from 1940 to 1990 for countries in SE Asia, sub-Saharan Africa and Latin America. They identified four broad clusters of direct causes: agricultural expansion, wood extraction, infrastructure extension, and other factors. Each category was further divided; for example, the cause of agricultural expansion was further broken down into permanent cultivation, shifting cultivation, cattle ranching, and colonisation. Besides the direct causes, they found that underlying economic factors are prominent driving forces for tropical deforestation (81\%); institutional factors are involved in $78 \%$ of cases; and, technological factors in $70 \%$. In addition, cultural, sociopolitical and demographic factors are relatively less important drivers, with different effects in different regions. They concluded there was no universal link between cause and effect in analysing deforestation drivers. The causes and driving forces are often region-specific which means that deforestation dynamics are shaped by geographical and historical contexts. As Hansen et al. (2010), in their update on global deforestation make clear, understanding these proximate drivers is crucial not only to understanding how to deal with deforestation, but understanding where it is likely to occur in the future.

A recent research paper by Drigo et al. (2009) also showed that deforestation is the result of the complex interaction of many local factors related to demography, economics, technology, government policies and cultural attitudes, which defy easy generalisations. Therefore they recommended the collection of objective and representative cause-effect data linked directly to objectively observed land use changes.

These reviews, however, do not examine the role of biofuels in deforestation. The principal reason is that, as stated earlier, apart from a few exceptions such as Brazil and Zimbabwe ${ }^{11}$, biofuel development in tropical countries only started in most places in the last five years, while the studies are based on data from the 1990s.

11 Ethanol production started in Zimbabwe during the 1970 s when the then Southern Rhodesia was largely cut off from normal trade because of its unilateral declaration of independence from Britain. After the overthrow of the Smith regime in 1980, these barriers were removed, and ethanol could not compete with the price of petroleum. Production fell dramatically and soon ceased, although the Triangle Sugar Corporation announced in 2008 that it would be resuming ethanol production 'shortly'. 


\subsubsection{Synthesis of the challenges related to deforestation}

Deforestation is a complex process and getting reliable estimates at the global level remains a challenge. The main issues are related to differences in definitions, poor reliability of the available global deforestation data, and limited time-series data for recent years, and restrictions in the spatial resolution of the satellite images for mapping deforestation at the global level. Finally, it is difficult to attribute deforestation to particular drivers. The large-scale development of biofuels is very recent, which adds to these problems.

\subsection{Challenges related to biofuels}

On the biofuel production side, estimating its role in deforestation is severely hampered by:

- Lack of detailed spatial information about where, within any given country, feedstocks are being cultivated.

- Lack of information about the individual production levels and location of biofuel plants at a global level.

- Many feedstocks used for biofuels have other uses as food or fodder, and in most cases, these other uses tend to dominate.

\subsubsection{Limited availability of production data}

No good universal and easily accessible global databases presently exist, either on feedstock production, or ethanol or biodiesel production. What data are available e.g. from F.O. Licht, are not spatialised but expressed as totals per country, or in large countries, per state; for example, in Brazil's case. Moreover, biofuel is a relatively new topic and what data are available are often not in the public domain, because of the commercial interests involved.

To correlate biofuel production with deforestation, it would be necessary to work at the subnational level and in spatial terms. Ideally data would be needed on: a) different types of feedstock production at a relatively detailed level of disaggregation (such as the municipal level) in terms of area and crop yield; and, b) clear indications of how much of each feedstock in each location is processed into biofuel and how much is used for other purposes (food, soap, cosmetics and so forth), with data of both types in time series that can be compared to time-series data on deforestation.

Unfortunately this data is simply not available. Databases that provide information on the volumes of biofuels processed only have data at a high level of aggregation (usually national totals per year; in some cases, data is given at the state or province level); data at lower levels (district, municipal levels) are not available with the exception of certain countries including Brazil ${ }^{12}$.

\subsubsection{Multipurpose nature of most biofuel feedstocks}

Many biofuel feedstocks are multipurpose, so that data on the area planted to palm oil and the yield per hectare do not provide an indication of the biofuel output since palm oil is also used for food and cosmetic products. Studies that do not take into account the multipurpose characteristics of biofuel feedstocks commit the error of overestimating its production impacts on the environment. The fuel and non-fuel distinction is crucial, but hardly any data is available that would enable the spatial identification of the 'dedicated' plantations for the most prominent feedstocks (sugar, soya, palm oil, maize, even castor). An exception is some crops usually intended only for biofuel production, such as jatropha.

In addition, data from databases that list individual production plants tend to be limited because of commercial secrecy; they provide data on plant capacity rather than on actual production levels and usually organise the data in broad ranges (i.e., large, medium and small), although a simple count of

12 Twenty-one websites were investigated to acquire data. These websites were categorised into three types based on whether the information found would be useful for obtaining data for this global study. Among the visited websites, only two have data that can be used to obtain global biofuel data: one is from worldbioplants.com, which sorted global biofuel plants information by country, and the other is from an FAO report, 'The state of food and agriculture 2008'; three websites supply information on Ghana biofuel feedstocks areas, which is useful when the study goes to biofuel hotspots information for the case studies; two other websites, from the Earth Policy Institute and Science for Global Insight respectively, have data only partially useful for supplying background information; one local website from the Association of Soya Producers of Mato Grosso has data too limited to use for global study. The details of the websites investigated are listed in Appendix 4. 
the number of processing plants listed by country gives some notion of the level of biofuel activity (Figure 6 in Appendix 2), though not of course an accurate picture since no data is available on the actual production at each site, as this information is considered commercially sensitive in many cases. The addresses of these plants may be available, but their location is only a proxy indicator of biofuel production since their presence is not always directly correlated with where the biofuel crops are being cultivated, and thus difficult to relate to deforestation ${ }^{13}$. Moreover, as noted, the quantity of biofuel produced at individual plants is rarely available in these databases, so it is not possible to calculate backward the feedstock quantities.

The uncertain link between locations of feedstock cultivation and locations of processing plants is also affected by the different nature of processing for different feedstocks. Biofuel feedstocks such as sugarcane, soya, and palm oil follow different paths in their processing. Sugarcane, if used to produce fuel, is directly pressed to produce a solution of sugar which is then converted to ethanol, usually at a single plant. Because of the cane's weight, sugar ethanol is usually processed close to the feedstock production areas. Soya, on the other hand, first needs to be pressed, and then separated into soy meal and soy oil (roughly 80: 20). The oil is then processed to produce biodiesel. Since soy oil is relatively compact, it can be transported relatively easily, which means that the biodiesel processing plants may not be in the same locations as the crushing plants.

\subsubsection{Allocating the deforestation burden to biofuels}

In cases where feedstocks are not used solely for biofuel but for several commodities, even if the share of the feedstock expansion in total direct deforestation is known, allocating the share of this deforestation to the different end products poses some methodological problems. This is illustrated

13 For example, in Brazil, biofuel production plants are concentrated near the coastal cities. This is probably related to export opportunities, with feedstock transported by road or rail to processing centres from various parts of the country. Of course, the location of biofuel processing plants could be an indicator of the location of feedstock production, particularly up country, but it is not a complete indicator of all feedstock production. here in the case of soy in Mato Grosso, Brazil, in Table d in Appendix 5, Section 1.6, and explained in detail below.

Approximately $18 \%$ of the total primary product (i.e. of the soy bean) by weight is oil, the rest is cake or meal, primarily used for cattle feed. Not all the oil is, however, used for biodiesel, as much is processed for cooking oil. In Brazil's case, we estimate the maximum share of soy oil that may be processed to biodiesel is 35\% (on the basis of the quantity of soy oil needed to meet Brazil's biodiesel 5\% mix requirement (Hall et al. 2009)). This is a conservative (high end) estimate, since other crops (sunflower, etc.) are also used to make biodiesel in Brazil. A further relevant fact is that only between 16-20\% of forest clearance in Mato Grosso is brought about by cultivation (Nepstad et al. 2009; Morton et al. 2006); the remaining $>80 \%$ is the result of pasture expansion for grazing. Moreover, not all the cultivation area is used for soy; recent estimates suggest that it represents $84 \%$ (Wright 2009), not taking into account the fact that a second crop, usually maize, is grown on the same land every year.

With this data, the burden of direct deforestation to this biodiesel can be allocated in at least three ways:

\section{Direct deforestation allocated on the basis of the share of primary product weight. In this} case, biodiesel's deforestation share is calculated as the multiple of: a) per cent of total deforestation due to cultivation;(b) per cent of cultivation dedicated to soy;(c) per cent of soy oil in the total weight of soy seeds; and, d) per cent of oil converted to biodiesel rather than into other products. This suggests that only 0.8 to $1.0 \%$ of all deforestation in Mato Grosso can be attributed to biodiesel (line J1 in Table d, Appendix 5 , Section 1.6).

\section{Deforestation allocated on the basis of} economic value. It can, however, be argued that deforestation is more likely to be affected by the relative economic value of the different products rather than by their relative weight, and that therefore the deforestation shares should be weighted by market prices. Per metric tonne, soy oil trades at approximates three times the value 
of soy meal (the ratio was $\$ 599 /$ ton to $\$ 209 /$ ton in 2006 , and $\$ 1423 /$ ton and $\$ 466 /$ ton in 2008, according to World Bank commodity trading records (http://siteresources.worldbank. org/ INTDAILYPROSPECTS/ Resources/ Pnk_0908.pdf). Following the above calculation but substituting the relative value rather than the relative weight in c), biodiesel is estimated to cause $2.0-2.5 \%$ of Mato Grosso's deforestation (line J2, Table d, Appendix 5, Section 1.6).

\section{Deforestation allocated in terms of actual area} sown with soy. A more conservative estimate, however, would suggest that soy oil and soy meal are in fact inseparable; without the one there is none of the other, so that the total area sown for soy should be considered deforested for soy oil. On this basis, the deforestation burden attributable to biodiesel would be $35 \%$ of the total soy area, or from $4.6-5.9 \%$ of all the deforestation taking place in the state of Mato Grosso (line K, Table d, Appendix 5, Section 1.6).

There is no accepted methodology for making this calculation. The three alternatives are presented here simply to illustrate the difficulties and the fact that the result — the area said to be directly deforested as a result of biofuel feedstock cultivation—can vary by a factor of six depending on which method is selected.

\subsubsection{Synthesis}

Ascribing deforestation to particular biofuels is difficult because feedstocks have multiple purposes, i.e. they are not solely_and sometimes not primarily — grown for biofuel production, as the case of soya shows. Also, the ratio of fuel-food/fodder varies year by year according to market conditions. Second, up to now, biofuels only represent a small fraction of total feedstock output. Third, it not possible to know the exact areas where production for biofuel comes from, because, with the exception of sugarcane, processing plants are not linked to specific production areas. Also, individual producers usually do not know the final destination of the feedstocks. Fourth, data on output of individual biofuel production plants are limited due to commercial secrecy, as well as the link between the locations of feedstock cultivation and locations of processing plants. A final (methodological) problem relates to the procedure used to allocate the deforestation burden for those feedstocks - like soya — where the biodiesel is only one of several end products with economic value. 


\section{Identification of the direct deforestation caused by biofuels}

From a spatial point of view, trying to match areas of biofuel production to deforestation presents scale and resolution challenges. In order to analyse the spatial correlation between deforestation and biofuel development, these two types of data need to be adjusted and presented at the same scale and with the same resolution. The deforestation data is area based and georeferenced, but the biofuel development data available are essentially either point data, as in the case of biofuel plants, or on the basis of administrative units, ranging from national to provincial levels. Expert knowledge is needed to identify particular locations of biofuel production at the subprovincial level.

\subsection{Main deforestation hotspots at the global level}

This analysis draws on MODIS Vegetation Cover Conversion (VCC) deforestation data designed and generated at the University of Maryland ${ }^{14}$, Department of Geography. The VCC deforestation product is distributed by the Global Land Cover Facility (GLCF) in GeoTIFF format. It is an 'early warning' product to be used as an indicator of change and not as a means to measure change. The deforestation data consist of information on change and no change, and the coverage extent is the tropics, between 30 degrees south and north. The mapping method for deforestation is derived from the original space partitioning method. It relies on decision tree classification to determine antecedent vegetation condition and compares that to current vegetation condition $^{15}$ (Zhan et al. 2002).

A mosaic was built based on 68 MODIS images in GeoTIFF format from which a global tropical deforestation map (2001-2005) was derived (Figure 5). This map only provides referential information about the location of deforestation since the image resolution is not sufficient to calculate the actual

14 The data are available from the GLCF through the link http://glcf.umiacs.umd.edu/index.shtml.

15 http://glcf.umiacs.umd.edu/library/guide/VCCuserguide. pdf. quantity of deforestation taking place at each identified site ${ }^{16}$. Comparing with FAO data, the identified figures are rather low, which reflects the limitations of using MODIS for detecting deforestation. Since deforestation that occurs in hilly areas cannot be well detected (Scales et al. 1997), it might not be ideal to use the same type of data for different types of landscapes for deforestation detection at the global level ${ }^{17}$.

Figure 5 shows that in the period 2001-2005, hotspots are concentrated in Latin America, and within that region, primarily taking place in the southern margins of the Brazilian Amazon, particularly in the states of Pará and Mato Grosso. This corresponds with the FAO forest inventory results of 2000 and 2005. Other regions showing relatively important magnitudes of deforestation are the northern portion of Argentina, Santa Cruz in Bolivia, northern Paraguay, and the northwest portion of Mexico as well as portions of the states of Chiapas, Michoacán and Yucatan. In SE Asia, the deforestation hotspots are located mainly in Indonesia, which corresponds also to the FAO forest inventory result. No evident deforestation was detected with this dataset during 2001-2005 in subSaharan Africa.

Figures 6 and 7 provide examples of deforestation hotspots (2001-2005) located in Latin America and SE Asia. Figure 6 presents the case in Mato Grosso, Brazil, and Figure 7 the case in Sumatra, Indonesia. A more detailed review of the drivers and trends

16 Estimates of actual area from this map underestimate the true situation, giving deforestation estimates for Brazil as 3.79 million ha/year; Indonesia, 52000 ha/year; and Mexico, 76000 ha/year for 2000-2005. This is because the algorithm in the software avoids commission error at the expense of omission error. The typical mosaic pattern of deforestation in Indonesia is not well picked up by this methodology.

17 We then converted the format of the global deforestation map so it can be uploaded to Google Earth. This allows the user to zoom in to see exactly where deforestation is happening. In this way, deforestation information can be portrayed more vividly, since it can be checked with the satellite images in the background. This deforestation data in Google Earth format can be accessed at the project website: www.cifor.cgiar.org/ bioenergy/_ref/about/index.htm. 


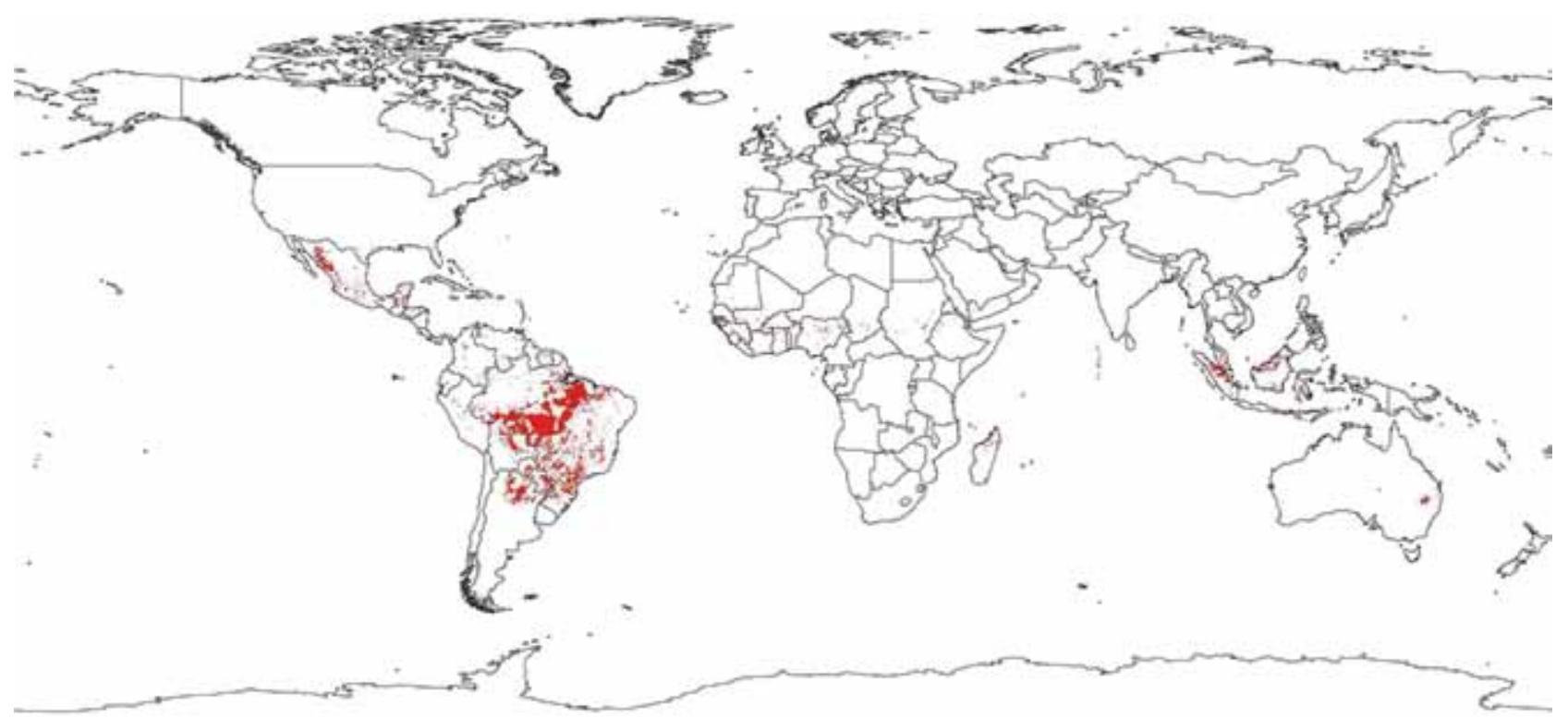

Figure 5. Global deforestation map (2001-2005) generated using MOD44A data (Carroll et al. 2006). A red area indicates that deforestation has been identified at this location, but does not represent the size of the area deforested

Note: To facilitate the display, the deforested areas are exaggerated, though the true information can be accessed and managed in any GIS software.

Table 6. Established biofuel hotspots

\begin{tabular}{|c|c|c|c|c|}
\hline Country & Province/region & Type of biofuel & Feedstock & Plantation areas $^{\mathrm{b}}$ \\
\hline Argentina & Santa $\mathrm{Fe}$, parts of Chaco, Santiago del Estero & Biodiesel & Soya $^{a}$ & 3.6 million ha (2006) \\
\hline Brazil & São Paolo & Bioethanol & Sugarcane & 4.2 million ha (2006) \\
\hline Brazil & Mato Grosso & Biodiesel & Soya $^{a}$ & 5.7 million ha (2008-09) \\
\hline Colombia & Valle de Cauca & Bioethanol & Sugarcane & 41000 ha \\
\hline Colombia & Zona Oriental & Biodiesel & Palm oil ${ }^{a}$ & $121135 \mathrm{ha}$ \\
\hline Indonesia & W. Kalimantan & Biodiesel & Palm oil & 367619 ha \\
\hline Malaysia & Sabah & Biodiesel & Palm oila & 1165412 ha \\
\hline
\end{tabular}

a In all these cases only a small fraction of the total oil produced is actually converted to biodiesel.

b The area shown for these feedstocks is used for both biofuel production and for food/fodder.

of deforestation in these two locales is provided in Appendix 5, along with some other selected hotspots.

\subsection{Main biofuel hotspots at the global level}

The identification of biofuel hotspots is based on available secondary information. Seven large and well-established biofuel hotspots are presented in Table 6. It is notable that only two (Mato Grosso in Brazil and Sumatra in Indonesia) coincide with the deforestation hotspots visually identified in the mapping exercise (Figure 5), meaning that either the biofuel development is not causing deforestation in five of the areas or (as described in detail above), mapping methodologies are not up to the task of honing in on patches of deforestation. For each of the seven hotspots, information is provided as regards location, the type of biofuel and feedstock, and also the information on plantation areas. The authors found that the information on plantation areas varies in different sources and we reference here the seemingly most reliable data source. Hotspots include Santa Fe State in Argentina (Lamers 2006); 

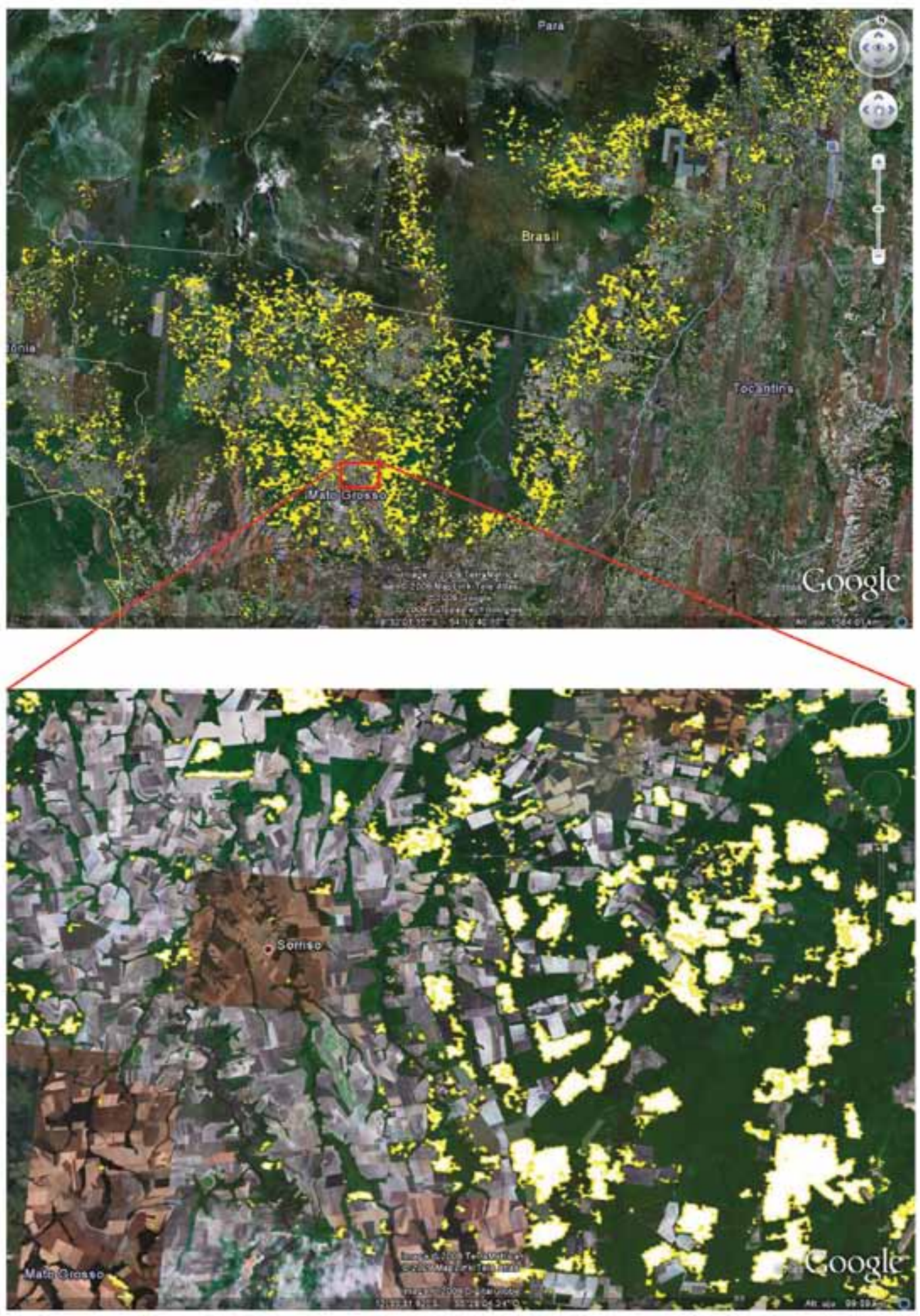

Figure 6. Deforestation 2001-2005 (yellow) in Mato Grosso, Brazil. The upper image covers the whole state of Mato Grosso; the lower image is a closer view of part of the area indicated by the small square in the upper image. 


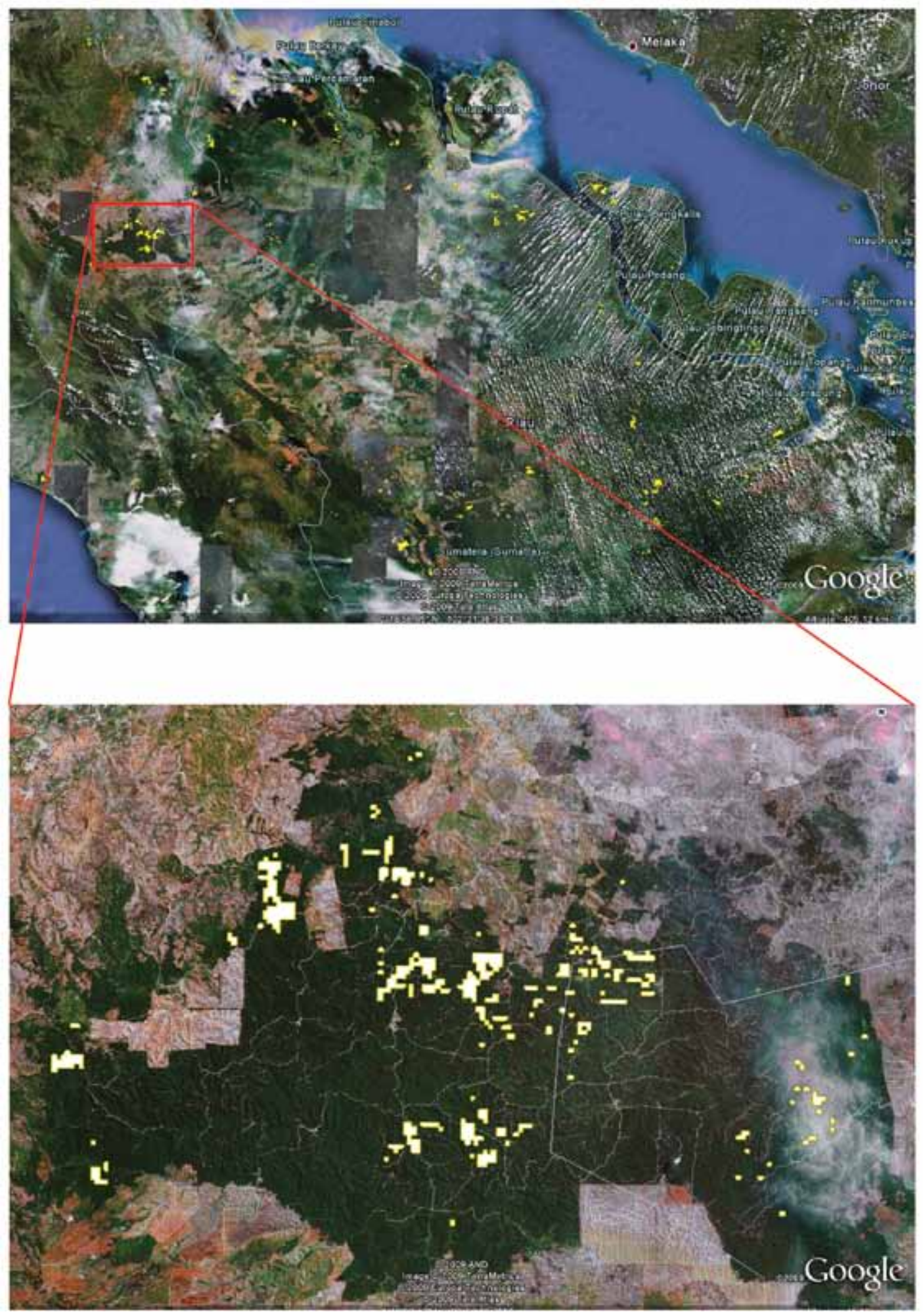

Figure 7. Deforestation detected in northern Sumatra, Indonesia during 2001-2005 presented on Google Earth image; yellow plots indicate deforestation 
Table 7. Examples of small-scale emerging biofuel hotspots: Biodiesel from jatropha

\begin{tabular}{llrr}
\hline Country & City or province & $\begin{array}{r}\text { Plantation areas } \\
\text { established (ha) }\end{array}$ & \multicolumn{1}{c}{$\begin{array}{l}\text { Plantation areas planned } \\
\text { (by when) (ha) }\end{array}$} \\
\hline Brazil & Minas Gerais & 13500 & 1.3 million (2015) \\
Mexico & Yucatán, Chiapas, Michoacán & 13000 & $100000(2010)$ \\
India & Tamil Nadu & 100000 & - \\
Ghana & Brong Ahafo, Northern Ashanti & $7000-8000$ & $>100000$ \\
Madagascar & South West & 30000 & - \\
Mozambique & Gaza, Inhambane, Zambezi Delta & 10000 & - \\
Tanzania & Kisarawe & 13100 & - \\
Zambia & Southern Province & 35222 & - \\
\hline
\end{tabular}

Mato Grosso State in Brazil (APROSOJA 2010), where soya is grown for biodiesel production; São Paolo State in Brazil (Meloni et al. 2008); and, Valle de Cauca in Colombia where bioethanol is produced from sugarcane (Toasa 2009). Zona Oriental in Colombia is another important hotspot for biodiesel production from palm oil (FEDEPALMA 2009). In SE Asia, West Kalimantan, Indonesia and Sabah, Malaysia are two important hotspots where palm oil is the main feedstock (Potter 2008; Wahid et al. 2004).

Meanwhile, many much smaller biofuel hotspots are emerging, which are much less well documented, perhaps because most are relatively new as well as several orders of magnitude smaller than the ones listed in Table 6. Table 7 shows a selection of some emerging jatropha hotspots; this feedstock is utilised almost exclusively for biofuel production, unlike soy, palm oil and sugar. The plantation area is therefore actually the area of the biodiesel feedstock. In Latin America, we noted the cases of Minas Gerais, Brazil, and Mexico where biodiesel production from jatropha is starting on a very small scale in the states of Yucatán, Michoacán and Chiapas (GEXSI 2008a). In Asia, India is expanding its production of jatropha for biodiesel production (GEXSIb 2008). In sub-Saharan Africa, jatropha production has been identified in Ghana, Madagascar, Mozambique, Tanzania and Zambia (GEXSI 2008c; Loos 2009; Ribeiro and Matavel 2009; Sulle and Nelson 2009; Schoneveld et al. forthcoming).

The identified global biofuel hotspots including both established and emerging ones are also presented in a global map in Figure 8. Since no information is available that indicates the hotspots' exact geographic locations, the hotspots are represented by the states where they are located. The biofuel hotspots data are very preliminary. For the cases that use multipurpose feedstocks, the plantation area data do not represent the feedstock used for biofuel, but rather the feedstock's total plantation area.

\subsection{Matching deforestation hotspots and biofuel hotspots at the global level}

The global deforestation map (Figure 5) and the global biofuel hotspots map (Figure 8) are compared. This shows that within Latin America, deforestation and biofuel production overlap in Brazil (mainly in Mato Grosso where biodiesel from soya is produced, but also to some extent in São Paolo, where ethanol from sugarcane is produced), and in the north of Argentina (Santa Fe, Santiago del Estero and Chaco provinces, where biodiesel from soya is produced). In Mexico, although there is some overlapping with deforestation in the Chiapas and Yucatán hotspots, this cannot be ascribed to biofuels, as plantation establishment is very recent (2007 onward). Within Asia, deforestation and biofuel production areas overlap in Indonesia and Malaysia, where biodiesel from oil palm is produced. The situation in sub-Saharan Africa is unclear, since plantation establishment for biofuels (mainly jatropha) is very recent and it is occurring either in regions of dry or seasonal dry forests, where MODIS is unable to detect deforestation, or on grassland as suggested by Croezen et al. (2010).

The global analysis provides a first step in identifying hotspots, but it is very limited and gives no indication about the magnitude of deforestation driven by neither biofuel development nor where 


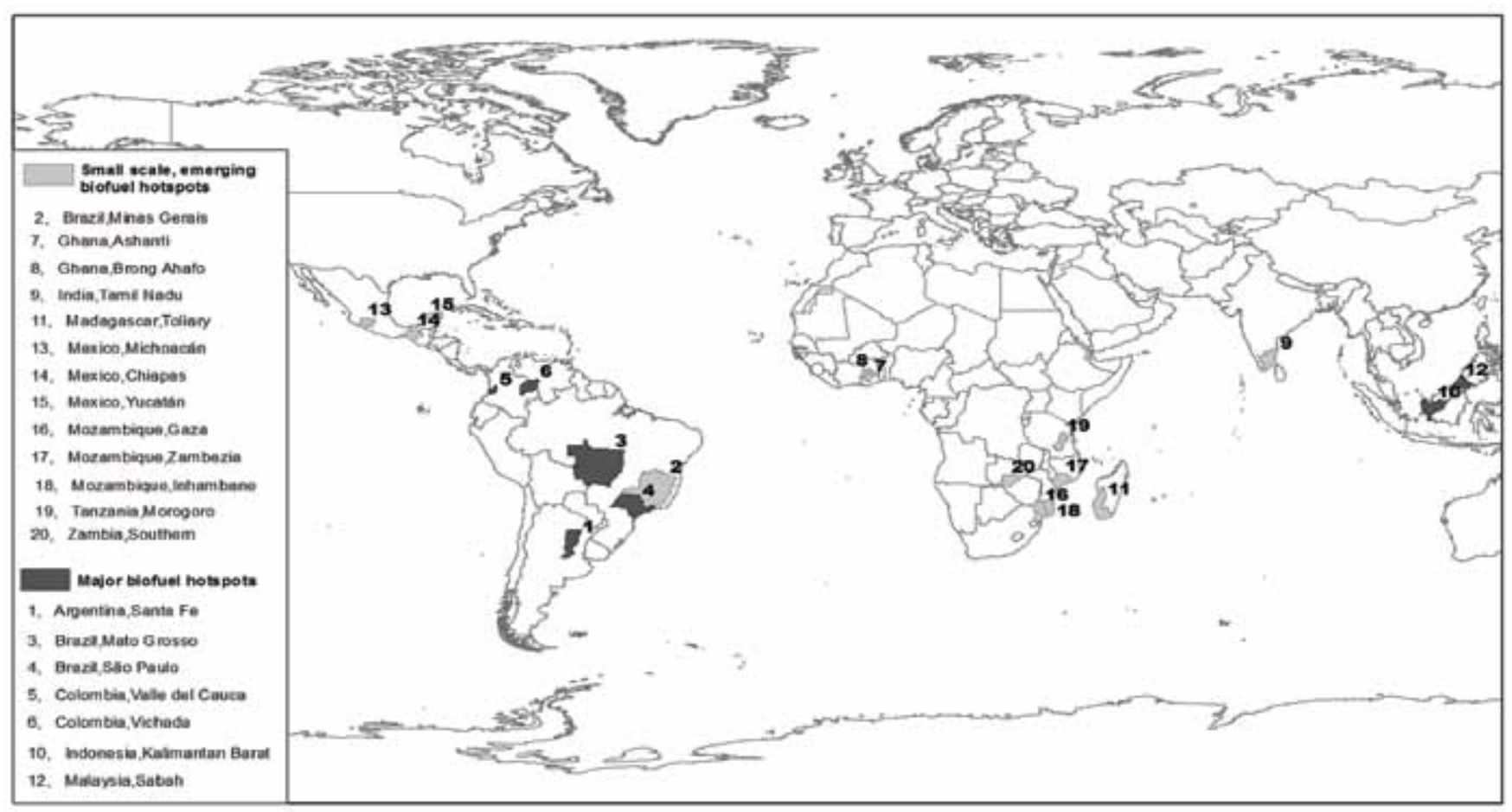

Figure 8. A preliminary map showing states or regions in which established global biofuel hotspots are located

the deforestation impact is direct or indirect. As mentioned before, low spatial resolution satellite images such as MODIS work better for detecting changes in landscapes where the contrast between forest and non-forest land is greater, but it is unable to detect changes that occur in tropical dry forest areas. Furthermore, the most significant limitation of this analysis constitutes the timing of the deforestation data employed (2001-05), since most biofuel expansion is likely to have occurred only in the recent years that are not captured by the deforestation information provided. Thereby, the limitation of this analysis justifies a more in-depth analysis using national and local information, which is provided in Appendix 5.

\subsection{Synthesis}

With the existing data it is not possible to obtain reliable estimates of biofuels' impact on deforestation at the global level. To assess its effects on deforestation, we would need to compare the loss of the forests with the increase in feedstock area devoted to biofuels within the same period. While coarse global deforestation data is available for 2001-2005, data on global biofuel hotspots are comparatively much poorer. First, the data on the hotspots are from different dates. Second, the data represent a single point in time, not the change across two time periods. Third, the location of the biofuel feedstock plantations in those hotspots is unknown. In fact, in the jatropha-based biofuel hotspots such as those detected in sub-Saharan Africa, and the cases of Mexico and Brazil, the plantation establishment is more recent than the deforestation map. Thus, an analysis of spatial coincidence at the global level cannot be conducted, although it brings out the possible study areas to focus on for analysis at the finer scales, such as the case study level.

The greatest of these problems is related to the lack of spatially explicit data on feedstock cultivation. Although total area cultivated per country (or per state in the case of very large countries) can be roughly estimated from national (or state) annual production levels of any given feedstock, until this data is standardly available at a much finer level of resolution (for example, municipal level), it will not be possible to overlay maps to assess spatial correlation between deforestation and feedstock production.

An alternative approach to study the relationship between deforestation and biofuel development in the near future would be to use a representative statistical sample. Purposive sampling would be used 
to focus on areas where it is known that feedstocks are sourced for biofuel processing. The necessary sample size would first be estimated with a view to obtaining a predetermined level of statistical probability of the results. Through geographical information system (GIS) processing, the direct feedstock-induced deforestation can be calculated. With local information on the proportion of the feedstock used for biofuels, an estimate of the biofuel-induced deforestation in the sample area can be obtained. However, this was beyond the scope of the current study. 


\section{Identification of the indirect deforestation caused by biofuel development}

In addition to deforestation directly caused by forest clearance to establish biofuel feedstocks, indirect clearance often takes place when agricultural activities are displaced to forested areas, causing deforestation elsewhere.

\subsection{Concepts and approaches to take iLUC into account}

ILUC (indirect Land Use Change) occurs when crops or land that would have otherwise been used for producing food or animal feed are used for growing biofuels, and existing agricultural production geographically shifts to new land areas created by converting natural areas (Croezen et al. 2010). ILUC often also works through the pricing mechanism, as the increased demand for biofuels drives up prices of agricultural commodities, which then increases the pressure on land and global ecosystems. These land use changes are named 'indirect', as they do not take place at the biofuel production site itself but elsewhere in the world, though triggered by events at the production site. Thus, the natural forests and grasslands in a specific region may be converted to cropland as a result of biofuel production being initiated in a different region (Liska and Perrin 2009; Kim et al. 2009; Croezen et al. 2010), as illustrated in Figure 9.

ILUC could lead to both changes in land use and changes in land management practices (for example, farmers responding to increasing prices by applying more fertilisers) which may have important consequences in terms of additional GHG emissions. These indirect emissions resulting from biofuel production should be considered in calculating the GHG implications of adopting biofuels.

The logic of iLUC impact on deforestation and GHG emissions is clear, but the significance is not, and measurement is highly problematic given the complexities of the economic and social systems that connect biofuel production with land conversion throughout the world. Empirical verification of iLUC due to recent expansion of the biofuel industry is problematic because those expansions constitute
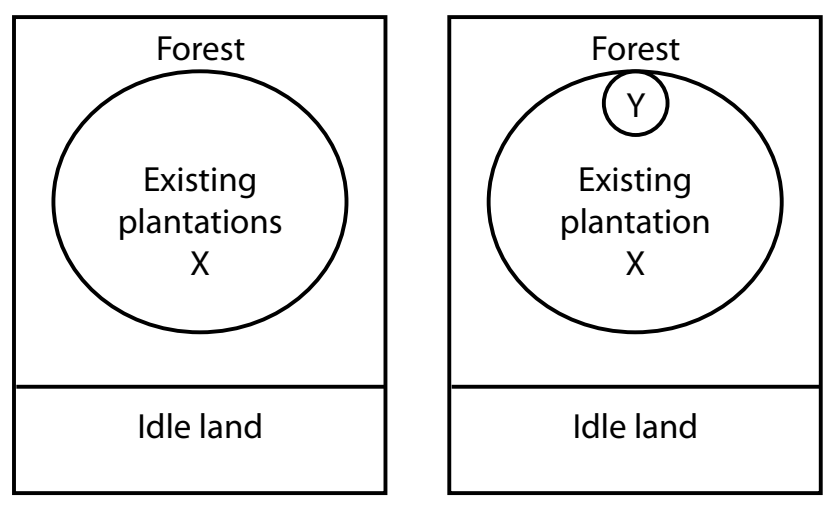

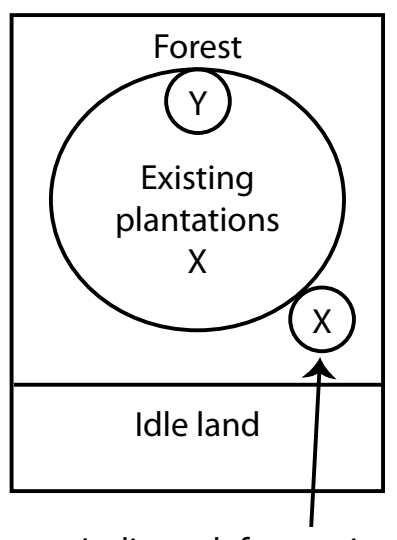

Indirect deforestation

Figure 9. A simple illustration of indirect deforestation. In the first figure, $X$ represents the area devoted, for example, to food production. In the second figure, $Y$ is the area formerly devoted to food production that has been replaced to establish biofuels. The third figure shows that, to meet the food demands, new forest areas are cleared (these areas may be contiguous to the existing agricultural land, as shown in the figure or may be in a different country). 
a very small driver relative to global LUC, so the biofuel component is likely to be swamped by other causes.

Therefore, iLUC due to biofuel must be evaluated with some type of modelling approach, and the results of some attempts to do this are described in the next section. It should be noted that these are sophisticated modelling exercises using econometric theory (they do not assume, for example, that switching corn production to biofuel results in $100 \%$ displacement and equivalent deforestation, but model this using estimates of prices and average land rents, among other variables). A drawback is that most models give quantitative estimates of resulting deforestation but cannot say where this will occur. It is possible that case studies could also offer some evidence useful in evaluating iLUC in the near future. Direct LUC effects are conceptually easier to consider since they link conversion of a specific piece of land in a given biofuel supply chain to resulting GHG emissions. In contrast, iLUC is highly controversial because it essentially makes biofuel industries responsible for the environmental consequences of decisions over which they have no control (Kim et al. 2009). The uncertainties in predictions reflect the limitations of economic methods, the uncertainty whether past economic relationships will remain the same in the future, and the uncertain responses of governments, which may facilitate or discourage conversion of some of the world's most carbon-rich habitats in response to increased demand for food (Searchinger et al. 2008; Kammen et al. 2007).

However, despite the inherent uncertainties in estimating iLUC, many authors argue that its emissions cannot be ignored; it is necessary to include iLUC, 1) to assess whether diverting managed lands into fuel production provides a net carbon gain or just moves carbon around; 2) to see whether the potential GHG benefits of diverting crops to biofuels actually result given the indirect effects; 3) because incorporating direct but not indirect LUC would be futile; and, 4) because opportunity cost analysis makes clear that iLUC emissions caused by diverting crops to biofuels may be substantial (Searchinger et al. 2009; Croezen et al. 2010). Thus for policymakers, it is important to take into account the many impacts of indirect land use change, for it is the summed impacts, intended and unintended, that determine whether a regulatory intervention has advanced, or retarded, the approach toward sustainability.

\subsection{Preliminary findings of the impact of indirect land use change}

The impact of iLUC from biofuel development has been analysed for US corn-ethanol, the EU 2020 directive on biofuels, and the Brazilian biofuel targets for 2020. For example, Searchinger et al. (2008) estimated that over a 10-year period, allocation of 12.8 Mha of corn to produce ethanol in the USA would result in 10.8 Mha of new cropland around the world, much of it involving forest clearance. When indirect effects are included in the carbon accounts for this biofuel, instead of producing a $20 \%$ saving, they produce nearly double the greenhouse emissions over 30 years and increased greenhouse gases for 167 years. The emissions estimated due to iLUC alone are higher than estimated emissions from the gasoline that the biofuel would replace. If this is correct, it eliminates any climate change benefits attributable to corn-ethanol. However, the study has been contested due to the many uncertainties in the modelling (Liska and Perrin. 2009). ${ }^{18}$

A previous study by Delucchi (2003) estimated that adding iLUC emissions from within the USA to the cumulative emissions intensity of corn-ethanol would increase its GHG intensity by $26 \%$, whereas Searchinger et al. (2008) calculated a 32\% increase in GHG emissions from the iLUC effect could be derived from US LUC attributable to ethanol. A more recent study using GTAP, a computable general equilibrium model, implied that 57 billion litres per year of additional corn-ethanol would result in a

18 The Searchinger study utilises a partial equilibrium model of world agricultural prices and land allocation. The model projected land allocations under two different petroleum price scenarios, which resulted in US ethanol production levels of 56 and 112 billion litres per year. All other policy and economic conditions were held constant to isolate the effect of US ethanol production on global LUC. The estimated annual marginal increase in global cultivated area due to increased ethanol was about 1.1 million ha per year, compared with recent increases of about 4.3 million ha per year during 1996-2005, or compared to forest losses of about 7.2 million ha per year (FAOSTAT). 

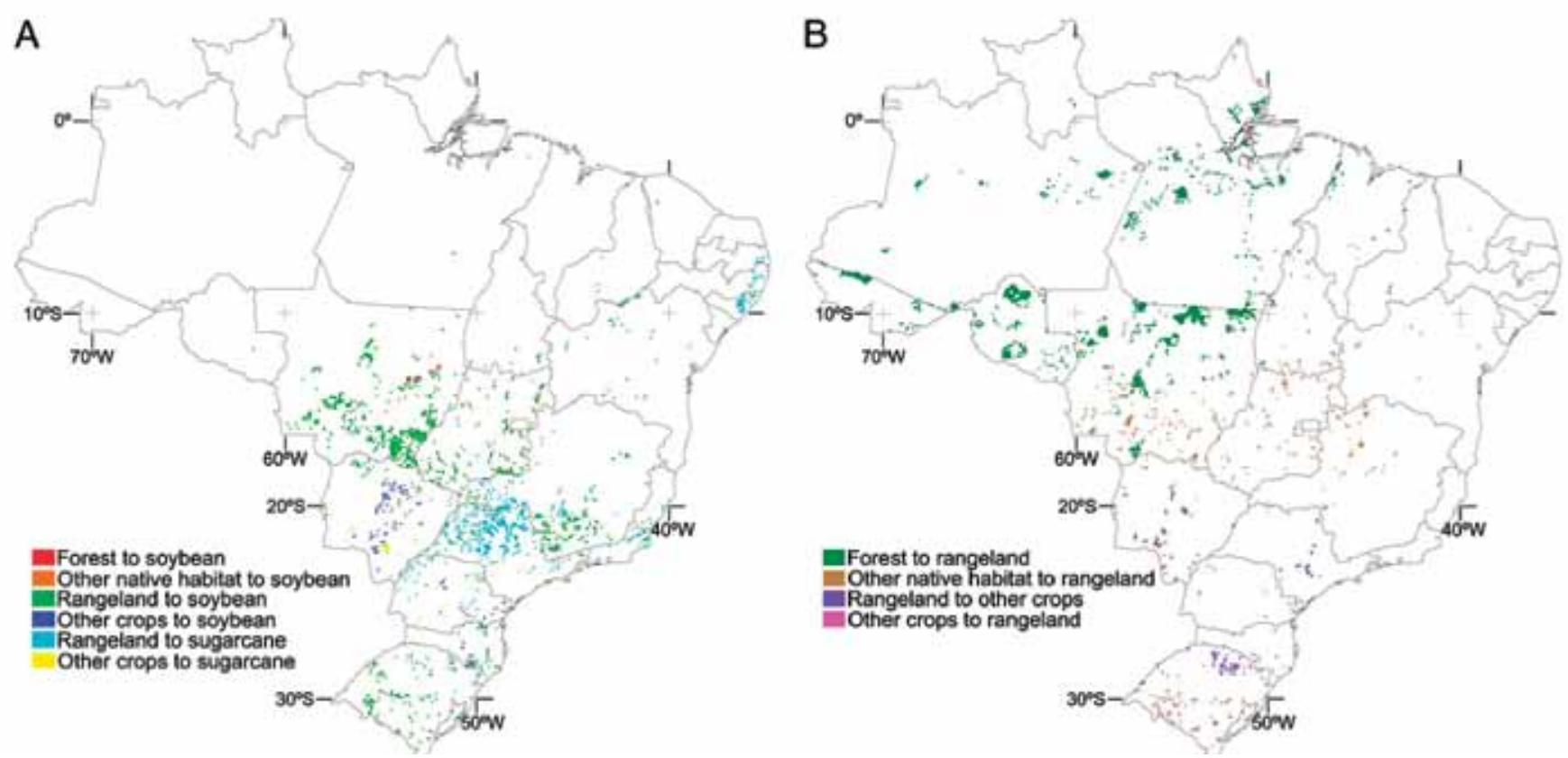

Figure 10. Direct (A) and indirect (B) land use change in Brazil due to the expansion of soybean and sugarcane production to meet the country's present biofuel targets for 2020. Most of the direct land use change occurs from rangeland to soybean in the state of Mato Grosso and from rangeland to sugarcane in the state of São Paolo, moving livestock production further into the Amazon where it causes deforestation (iLUC).

Source: Lapola et al. (2010)

global increase of 4 million ha when market effects are accounted for (Hertel et al. 2010).

In a very recent article Lapola et al. (2010), using a spatial explict modelling approach, estimated that while direct LUC from the expansion of biofuel production in Brazil to meet its 2020 targets (including both ethanol from sugarcane and biodiesel from soya) is very small, the iLUC may amount to a forest loss of 12.9 Mha in the period 2003-2020 (Figure 10), mostly due to the expansion of pasture lands into forested area. The authors suggest that most of this iLUC could be avoided by a modest increase in the intensity of livestock management in the remaining pasture lands.

In a comprehensive study about the iLUC impacts from the recent EU 2020 directive on biofuels, Croezen et al. (2010) indicated that the average iLUC factor ranges from $34-65 \%$ of the fossil fuel emissions for ethanol and between $43-68 \%$ for biodiesel, depending on model assumptions and the particular feedstock. The location of land use change also varies among models. In one case (the EU Joint
Research Centre simulation with AGLINK), the model predicts that one-third of the total expansion of arable land will occur in the EU itself, one-third in Latin America for sugarcane and soybean cultivation, and one-third through oil palm expansion in SE Asia as well as cereals and oilseeds area expansion in the USA, Canada and the Commonwealth of Independent States (CIS). In a contrasting case (the International Food Policy Research Institute (IFPRI) simulation with the Global Trade Analysis Project (GTAP)) the land use change related $70 \%$ or more to arable land expansion in Latin America for sugarcane and soybean cultivation.

\subsection{Synthesis}

Expansion of biofuels may lead to so-called indirect LUC (iLUC), which occurs when crops or land that would have otherwise be used for producing food or animal feed are used for growing biofuels, and existing agricultural production geographically shifts to new land areas created by conversion of natural areas. The actual impact of iLUC is very difficult to estimate as it depends on complex modelling 
approaches and has not been tested empirically yet. Current efforts have centred in estimating the potential iLUC impacts from planned future biofuel expansion in the EU, USA and Brazil. Different model approaches have been used with contrasting results in terms of total amount of land displaced, its geographical location, and the associated GHG emissions. However, most simulations suggest that iLUC is not negligible and will need to be included in future analysis. For example, in the case of the EU directive for 2020, average iLUC emission impacts range from $34-65 \%$ of the reference fossil fuel emissions for ethanol and between $43-68 \%$ for biodiesel. 


\section{Insights from the selected hotspots on biofuel development and deforestation}

Common sense indicates that expansion of any cropping, for example for biofuels, is likely to result in some level of deforestation, either directly or indirectly. Our analysis so far has been at the global level and our conclusions, after a detailed review of scholarly work on the topic, are that it is not possible at this level to quantify the relationship, for methodological reasons; both the data and the analytic capacity to assess, spatially correlate or model the relationship between these processes are lacking.

We therefore now turn to the analysis of individual biofuel hotspots, to determine whether at this level any clear relationships, patterns or trends can be identified. For this we have selected 11 hotspots for biofuel development in Latin America, SE Asia, and sub-Saharan Africa. In this section we draw on the more detailed descriptions of these hotspots which are given in Appendix 5. Table 8 presents the 11 cases, organised by region.

This sample has been chosen from among those identified earlier in this report, to represent the range of biofuel situations across the globe. Some hotspots are related to sugarcane expansion and bioethanol production (São Paolo in Brazil, and Valle del Cauca in Colombia). Others are cases in which oil palm is the main feedstock for biodiesel (Kalimantan in Indonesia, and Malaysia). The Mato Grosso case is included due to the importance of soybean expansion

Table 8. Selected biofuel hotspots

\begin{tabular}{llll}
\hline Region & Location & Feedstock & Biofuel \\
\hline Latin & Brazil, Mato Grosso & Soya & Biodiesel \\
America & Brazil, São Paolo & Sugarcane & Bioethanol \\
& Colombia, Valle de & Sugarcane & Bioethanol \\
& Cauca & & \\
& Colombia & Oil Palm & Biodiesel \\
& Brazil & Jatropha & Biodiesel \\
\hline Africa & Ghana & Jatropha & Biodiesel \\
& Tanzania & Jatropha & Biodiesel \\
& Mazambique & Jatropha & Biodiesel \\
\hline Asia & Indonesia & Palm oil & Biodiesel \\
& Malaysia & Palm oil & Biodiesel \\
& India & Jatropha & Biodiesel \\
\hline
\end{tabular}

for biodiesel. Finally, three cases in sub-Saharan Africa (Ghana, Tanzania and Mozambique) illustrate the expansion of diverse smaller scale biofuel developments, mainly to produce biodiesel from jatropha. These cases show both common general characteristics as well as contrasting ones.

The features common to the cases are:

1. With the exception of jatropha, biofuels are being developed in areas and sectors in which the feedstock was already well established for food or fodder; this is the case not only for sugarcane and oil palm, but also for soya.

2. Most biofuel feedstock is produced on large-scale plantations, though in some cases smallholders are also involved through outsourcing schemes.

3. Biofuel production in the region stimulates the incursion of large foreign companies into the sector, which tends to stimulate greater vertical integration.

The main way in which the cases contrast is that the biofuel sector is expanding in a relatively vigorous way in Brazil and Colombia in Latin America, and in Indonesia and Malaysia in southeast Asia, but is moving much more slowly in the African countries in spite of the initial expectations. The latter is due to uncertainties in the biofuel markets, and local socioeconomic and political conditions which hinder foreign investment.

From the 11 case studies examined, two cases are related to bioethanol production from sugarcane, the first in Brazil's São Paolo state and the second one in Valle del Cauca, Colombia. In both cases, sugarcane production has a long history, large-scale companies are involved, and government policies drive the crop expansion. Also in both cases, increases in the demand for bioethanol are the result of blending targets and associated incentives, and this has fuelled investments in the sugarcane sector, particularly in processing plants, leading to the sector's rapid modernisation. The latter has important economic implications in increasing the value of production, and expanding job opportunities. In Brazil, sugarcane 
expansion has increased the crop competition for land, although part of the production increase has been achieved through highly intensive cultivation systems. At the time sugar cultivation was started (long before the biofuel era), most of the land had been under pasture, and displacement of cattle at that time resulted in indirect deforestation, but the sugarcane expansion today is not thought to be resulting in further indirect deforestation. As for Valle del Cauca, while sugarcane plantations historically replaced all the primary vegetation, these plantations are not currently expanding to produce ethanol; rather part of the existing sugarcane area is shifting from producing sugar to producing ethanol.

The nine cases involving biodiesel production all demonstrate the same driving forces behind the expansion of production areas: available land, conducive government policy, and profitability. In Brazil, Indonesia and Malaysia, large-scale companies (Unilever, Cargill etc.) are involved throughout in the production chain. In Malaysia, the companies are either vertically integrated, such as Golden Hope/ Sime Darby, or independent producers, such as Carotino Sdn, Bhd. In Colombia the biodiesel plants are rather small compared to the other countries, though the sector is growing rapidly.

Depending on the model used (as shown in section 1.6, Table D in Appendix 5) the proportion of production due to biodiesel in Mato Grosso could range from $0.8 \%$ to $5.9 \%$. The case of palm oil in SE Asia is somewhat different. Between $6.5 \%$ and $2.8 \%$ of oil from oil palm is devoted to biodiesel in Indonesia and Malaysia, respectively. Since this crop produces nothing other than oil, it would therefore be conservative for biodiesel to be attributed with $2.8-6.5 \%$ of the deforestation due to palm oil, although in reality by no means all deforestation is due to palm oil, since other forms of agriculture (such as rice) are also expanding into the rainforest areas. While there is strong evidence (see Appendix 5, 1.3) that palm oil plantations in SE Asia are almost entirely associated with direct deforestation of tropical humid forests ${ }^{21}$, an additional factor is that

21 The Indonesian and Malaysian governments, however, claim that because canopy cover in the palm oil plantations is more than $30 \%$, this does not represent deforestation. Nevertheless, the carbon content of palm oil plantations is only about 40 tonnes per hectare compared to around 170 for the natural forest they replace, quite apart from the biodiversity and other amenity losses. some plantations have been set up on vulnerable soils that emit very large quantities of greenhouse gases when drained, as well as from the nitrogenous fertilisers applied (Danielsen et al. 2009; Murdiyarso et al. 2010; Hergoualc'h and Verchot 2010). Hence although the figure $2.8-6.5 \%$ may be helpful in estimating the above ground carbon losses due to palm oil in SE Asia, it may greatly underestimate the total emissions. Direct forest clearance for palm oil is, however, much less evident in Colombia. Here, forest clearance is mainly driven by pasture expansion, and oil palm expansion is primarily taking place on old pasture lands; in other words, the agriculture frontier is moving into the forest with cattle at the fore. As with all indirect land use changes, it is difficult to trace and quantify these impacts and further research is needed on this topic.

Soybean plantations in Mato Grosso, Brazil are associated both with clearance of cerrado (savanna forests) and with displacement of cattle rearing. The latter is bringing about indirect deforestation in the humid forests of the Amazon biome, although intensification of cattle rearing could prevent this, and it is starting on a very small scale in the transitional forest area. Within Mato Grosso, around four-fifths of forest clearance is related to grazing, and only one-fifth to cropping (which is mostly for soya). Since, as noted, about only about $35 \%$ of the oil is used to make biodiesel and assuming biodiesel takes the deforestation blame in terms of the area sown for soy (see section 3.2.3), this means that biofuel is responsible for a maximum of $5.9 \%$ of the direct deforestation in this state, although as noted, there are undoubtedly also indirect deforestation effects.

In sub-Saharan Africa, Brazil and India, jatropha plantation for biodiesel production is still in its infancy but appears to take place mostly in dry forest areas and on land earlier devoted to other crops. The jatropha case studies show some unique features, as jatropha is a feedstock exclusively oriented to biodiesel production, and has been promoted as a crop that can be grown on marginal lands. Nevertheless, evidence is increasing that jatropha is being planted on crop lands, displacing food production, or in areas cleared from forests, perhaps because yields are very low when it is grown on degraded fields and other wasteland. In the cases examined in sub-Saharan Africa, most investment 
is located in forest transition zones (Ghana), in regions of high conservation value (Tanzania), and in forests and wetlands (Mozambique), so the risk of biofuel-induced deforestation is substantial. It appears that in Brazil, jatropha seems to have an indirect effect on deforestation as food crops and pasture lands are being replaced. India shows the emergence of competition between devoting the lands to traditional fuels, i.e. charcoal production, which is the current use of the land, versus expanding jatropha plantations for biodiesel. If not properly managed, this latter competition may be exacerbated by the introduction of second-generation lignocellulosic biofuels.

\subsection{Synthesis}

Even from the analysis of hotspots it is difficult to obtain quantitative results on how much deforestation is being caused by biofuel development. Ethanol from sugarcane is more linked to indirect deforestation in Brazil and Colombia, and as such is much more difficult to trace and quantify. Palm oil, at least in southeast Asia, is associated with major clearance of humid forests, although not more than $6.5 \%$ of this deforestation in Indonesia can be blamed on biodiesel and 2.8\% in Malaysia. We estimate that biodiesel from soybean in Mato Grosso is responsible for not more than $7 \%$ of the direct deforestation in this state. Even jatropha, conventionally presented as a crop that grows on wasteland, has been shown to result in direct deforestation in some of our hotspot cases. 


\section{Deforestation and second generation biofuels: Future challenges and opportunities}

Second generation biofuels are being actively promoted at the international level as a way to solve some of the environmental and social concerns raised by first generation biofuels, such as those examined in this report. Of particular interest for our study on deforestation are second generation biofuels that come from woody biomass. These fuels are expected to be commercially viable in the coming 5-10 years, raising a new set of challenges and opportunities for the forest sector.

Specific challenges to be addressed with regards to deforestation and second generation biofuels, in addition to those present with first generation biofuels, include the potential competition with demand for fibre (e.g. timber and pulp) and the direct competition with fuel for subsistence or commercial purposes (such as fuelwood and charcoal), particularly within developing countries. While large uncertainties remain over the exact technical efficiencies achieved by these fuels, and thus on their specific land impacts, it is clear that a new set of studies is needed very shortly to help minimise the negative effects on native forests of potentially displacing forest harvesting activities for fibre and woodfuel.

Concerning direct and indirect LUC from food production displacement alone, a very recent article by Havlík et al. (2010) shows that the relative impact of second generation biofuels on deforestation compared with first generation depends critically on the lands used to establish the new crops. If second generation biofuels are to be produced on current agricultural land (cropland and pastures) using short rotation biomass plantations, they may increase the relative iLUC. On the other hand, if second generation biofuels were produced from wood from forests managed in a sustainable way, they would help reduce $50 \%$ of the iLUC relative to first generation biofuels. More studies are needed to confirm these results. Clearly, if a significant proportion of second generation biofuels can be established on degraded non-agricultural lands, then part of the competition for food, fibre or fuel may be reduced as well. 


\section{Conclusions and issues for further study}

This initial study indicates that the relationship between biofuel development and tropical deforestation is complex, and very difficult to detect and quantify at the global level. A quantification of the problem is precluded by limited data availability, lack of time series with sufficient resolution at global scale, the multipurpose nature of many feedstocks where biofuels are only part of a larger production system devoted also to food and fodder, and the very recent boost to biofuel production in most regions. In addition, deforestation is not only directly caused by biofuel establishment, but also has indirect effects, which take effect across entire regions or the world at large, and which will be increasingly important as large-scale biofuel development takes place. Up to now, however, there is no accepted method to estimate these indirect effects on deforestation. For this reason we have not been able to quantify the relation between deforestation and biofuel development at the global scale; we hope, however, that this study serves to prompt more research into this critical area. As a way to move the analysis forward, 11 hotspots were selected from Latin America, SE Asia and sub-Saharan Africa, where the relationship between biofuel development and deforestation could be explored more at length.

The rate of expansion of biofuels depends a great deal on conducive government policies and on foreign investment. Producer countries that have defined clear incentives and targets to stimulate biofuel production, either for domestic or foreign markets, have tended to expand their production capacity more rapidly. Yet the impacts on land use and forest cover change depend on a wider set of conditions that are strongly linked to the agricultural sector's performance. Conditions include, for example, the amount of available land for feedstock production, the comparative advantages of biofuel crops versus other food crops, the technologies and financial capital for agricultural production which landholders have access to, existing land use regulations, and the technical capacity of state agencies to enforce such regulations.
Regarding feedstocks, the analysis of 11 hotspots suggests that sugarcane appears to be largely grown on land cleared for agriculture long ago and it mainly replaces other field crops or pasture lands. Thus expanded production of ethanol from sugar is unlikely to cause direct deforestation, although it may cause indirect effects through displacement into new areas; this effect may be exacerbated by other factors such as rising food prices. Soya, on the other hand, is in general a pioneer crop, which is frequently produced on agricultural frontiers, on forestlands cleared for this purpose or in areas already cleared for pasture; here direct and indirect effects on deforestation are likely to be significant, although the proportion that can be associated with biodiesel is still small. Oil palm plantations are almost universally found in rainforest areas specifically cleared for this purpose, but so far the expansion has been more related to oil production than biofuels. However, the impact may be significant in the future if some governments keep to ambitious biofuel targets involving new concessions within rainforest areas, as in Indonesia. Jatropha has been promoted as a crop that uses 'wastelands' or field margins considered to be abandoned agricultural lands, but in reality it also appears to be grown in forest areas. Preliminary findings from sub-Saharan Africa indicate that vast amounts of lands have been acquired for establishing jatropha plantations - a portion of them within or surrounding closed forests-without any proper land use planning. Also, in many cases, the lands acquired have not been planted, indicating speculation in advance of the biofuel market expanding.

Our review of 11 selected hot spots also shows considerable market demand for biofuel, supported by government policies, with resulting economic pressure by private firms for land. If negative environmental impacts such as deforestation are to be avoided, it is evident that in-country institutions will need to develop the regulations and capacity to counter these forces and to promote sustainability concerns. The current economic crisis, which hasperhaps temporarily_slowed down the biofuel 
boom, could provide a good opportunity for national governments to reassess current targets and to build appropriate institutions at both the local and international level to help cope with these concerns. Efforts such as the Roundtable on Sustainable Biofuels (RSB), and the Brazilian Soy Moratorium are encouraging in this regard.

We would like to finish this report by suggesting that, in addition to clearly needed research work, particularly on indirect deforestation impacts, more research is needed on the potential deforestation impact of second generation 'woody' biofuels. These biofuel feedstocks are potentially much more carbon efficient that agricultural feedstocks, but initial studies suggest that their impact on food production may be substantial if short-rotation plantations are established on former agricultural land. Also, the potential deforestation and forest degradationinduced effects of second generation biofuels due to the competition for fibre and traditional fuel-particularly if they displace fuelwood and charcoal supplies in developing countries-may be very significant if not properly addressed. These issues should be addressed before second generation biofuels become the popular alternative to those of the first generation. 


\section{References}

Achard, F., DeFries, R., Eva, H., Hansen, M., Mayaux, P. and Stibig, H-J. 2007 Pan-tropical monitoring of deforestation. Environment Research Letters 2(4): 1-11. doi: 10.1088/17489326/2/4/045022.

Achten, W.M.J., Maes, W.H., Aerts, R., Verchot, L., Trabucco, A., Mathijs, E., Singh, V.P. and Muys, B. 2010 Jatropha: From global hype to local opportunity. Journal of Arid Environments 74: 164-165.

Achten, W.M.J., Verchot, L., Franken, Y., Mathijs, E., Singh, V.P., Aerts, R. and Pluys, B. 2008 Jatropha biodiesel production and use. Biomass and Bioenergy 32(12): 1063-1084.

Agencia Nacional de Petroleo (ANP) 2009 Boletim Mensal de Biodiesel: SRP. ANP, Brasilia.

All Africa 2009 Shareholders welcome the demise of Procana, 24 December. http://allafrica.com/ stories/200912240491.html (20 January 2010).

Angelsen, A. and Kaimowitz, D. 1999 Rethinking the causes of deforestation: lessons from economic models. World Bank Research Observer 14: 73-98.

APROSOJA (2010) Safra de soja 2009/2010. Associacáo dos Produtores de Soja do Estoado Mato Grosso. http://www.aprosoja.com.br/ novosite/estatisticav.php?cate=1 (15 April 2009).

Arnold, M., Bergman, M. and Djurfeldt, G. 1987 Evaluation of the SIDA Supported Social Forestry Project in Tamil Nadu.

ASOCAÑA (La Asociación de Cultivadores de Caña de Azúcar de Colombia) 2010 Estadistica balance azucarero 2010. Bogotá, Colombia.

Bangun, D. 2006 Indonesian palm oil industry. National Institute of Oilseed Products Annual Convention, 21-25 March.

Biopact 2007 CNOOC to build three biodiesel plants in west Kalimantan, Indonesia. http:// news.mongabay.com/bioenergy/2007/05/ cnooc-to-build-3-biodiesel-plants-in.html (2 October 2009).

Biofuel Watch Centre (BWC) 2008 Brazil of biofuels: impacts on crops on land, environment and society. Reporter Brazil, Biofuel Watch Centre. São Paolo, Brazil.
Biofuel Watch Centre (BWC) 2009 Brazil of Biofuels: Sugarcane 2008. Impacts of crops over land, environment and society. Reporter Brazil, Biofuel Watch Centre. São Paolo, Brazil.

Branford, S. and Freris, N. 2000 One great big hill of beans. The Ecologist 30: 46-47.

Brazilian Forum of NGOs and Social Movements for Environment and Development (FBOMS) 2005

Relation between expansion of soy plantations and deforestation. Forests Working Group of FBOMS, Brasilia, Brazil.

Brazilian Institute of Geography and Statistics (IBGE) 2009 Pesquisa Agrícola Municipal. Rio de Janeiro, Brazil.

Brown, L.R. 2004 Outgrowing the Earth: the food security challenge in an age of falling water tables and rising temperatures. Norton, New York.

Carrol, M. L., DiMiceli, C.M., Townshend, J.R.G., Sohlberg, R.A. and DeFries, M.C. 2006 Vegetation cover conversion MOD44A, burned vegetation, collection 4. University of Maryland, College Park, Maryland.

Casson, A. 2000 The hesitant boom: Indonesia's oil palm sub-sector in an era of economic crisis and political change. CIFOR Occasional Paper 29. Bogor, Indonesia.

Colchester, M., Pang W.A., Chuo, W.M. and Jalong, T. 2007 Land is life. Land rights and oil palm development in Sarawak. Forest Peoples Program and Perkumpulan Sawit Watch.

Conservation International 2009 Biodiversity hotspots. http://www.biodiversityhotspots. org/xp/hotspots/ghats/Pages/default.aspx (13 January 2010).

Cornelissen, S., Dehue, B. and Wonink, S. 2009 Summary of approaches to accounting for indirect impacts of biofuel production. Ecofys, The Netherlands.

Croezen, H.J., Bergsma, G.C., Otten, M.B.J. and van Valkengoed, M.P.J. 2010 Biofuels: indirect land use change and climate impact. CE Delft, Delft, The Netherlands.

Danielsen, F., Beukema, H., Burgess, N., Parish, F., Bruehl, C., Donald, P., Murdiyarso, D., Phalan, 
B., Reijnders, L., Struebig, M. and Fitzherbert, E. 2009 Biofuel plantations on forested lands: double jeopardy for biodiversity and climate. Conservation Biology 23(2): 348-358.

Deininger, K. 2009 Land grab, development opportunity, and securing rights: interim findings from a global study. Presentation, World Bank, Washington DC.

Delucchi, M. 2003 A lifecycle emissions model (LEM): lifecycle emissions from transportation fuels, motor vehicles, transportation modes, electricity use, heating and cooking fuels and materials. Institute of Transportation Studies UCD-ITS-RR-03-17. University of California, Davis, CA, USA.

Demirbas, A. 2009 Political, economic and environmental impacts of biofuels: a review. Applied Energy 86(1001): S108-S117.

Departamento Nacional de Planeación (DNP) 2008 Lineamientos de política para promover la producción sostenible de biocombustibles en Bolivia. Documento CONPES 3510. Consejo Nacional de Política Económica y Social, Departamento Nacional de Planeación, Bogotá, Colombia.

Dossche, V. and Ozinga, S. 2008 When the solution is the problem: the EU and its policies on agrofuels. Bioenergy and Forests. Briefing Note 1.

Drigo, R., Lasserre, B. and Marchetti, M. 2009 Patterns and trends in tropical forest cover. Plant Biosystems 143(2): 311-322.

Duraes, F.O.M. 2009 Programa de Pesquisa, Desenvolvimento e Inovação de Pinhão Manso. I Congresso Brasileiro de Pesquisa em Pinhão Manso (CBPPM). Brasilia, Brazil.

East African, The 2009 Public fury halts onslaught on farmers, 5 October. http://www.theeastafrican. co.ke/news/-/2558/667648/-/item/1/-/wst89tz/-/ index.html (25 November 2009).

Etter, A., McAlpine, C., Wilson, K., Phinn, S. and Possingham, H. 2006 Regional patterns of agricultural land use and deforestation in Colombia. Agriculture Ecosystems and Environment 114: 369-386.

Fearnside, P.M. 2001 Soybean cultivation as a threat to the environment. Environment Conservation 28: 23-38.

FEDEPALMA (Federación Nacional de Cultivadores de Palma de Aceite) 2009 Anuario estadístico 2009. Bogota, Colombia,
Fischer, G., van Velthuizen, H., Shah, M. and Nachtergaele, F. 2002 Global Agro-ecological assessment for agriculture in the $21^{\text {st }}$ century: methodology and results. International Institute for Applied Systems Analysis, Laxenburg, Austria.

F.O. Licht (Licht Interactive Data) 2007 Database of world commodity statistics. http://www.agranet. $\mathrm{com} /$ porta/home.jsp?pagetitle=showad\&publd= ag083 (June 2011).

F.O. Licht (Licht Interactive Data) 2009 Database of world commodity statistics. http://www.agranet. $\mathrm{com} /$ porta/home.jsp?pagetitle=showad\&publd= ag083 (June 2011).

Food and Agriculture Organisation (FAO) 2006 Choosing forest definition for the clean development mechanism. Forest and Climate Change Working Paper 4. FAO, Rome.

Food and Agriculture Organisation (FAO) Regional Office for Asia and the Pacific 2008 The State of Food and Agriculture in Asia and the Pacific region 2008. RAP Publication 2008/03.

Friends of the Earth, LifeMosaic and Sawit Watch 2008 Losing Ground: The human rights impacts of oil palm plantation expansion in Indonesia. Friends of the Earth, London.

Garcez, C.A. and Vianna, J.N.D.S. 2009 Brazilian Biodiesel Policy: Social and environmental considerations of sustainability. Energy 34.

Geist, H.J. and Lambin, E.F. 2002 Proximate causes and underlying driving forces of tropical deforestation. Bioscience 143-150.

Gesellschaft für Technische Zusammenarbeit (GTZ) 2005 Liquid biofuels for transportation in Tanzania: potential and implications for sustainable agriculture and energy in the $21^{\text {st }}$ Century. GTZ, Eschborn, Germany.

GEXSI (Global Exchange for Social Investment) 2008a.Global market study on jatropha. Project inventory: Latin America. Prepared for the World Wide Fund for Nature (WWF), London/Berlin.

GEXSI (Global Exchange for Social Investment) 2008b Global market study on jatropha. Project inventory: Asia. Prepared for the World Wide Fund for Nature (WWF), London/Berlin.

GEXSI (Global Exchange for Social Investment) 2008c Global market study on jatropha. Project inventory: Africa. Prepared for the World Wide Fund for Nature (WWF), London/Berlin.

Gibbs, H., Johnston, M., Foley, A.A., Holloway, T., Monfreda, C., Ramankutty, N. and Zaks, 
D. 2008 Carbon payback times for crop-based biofuel expansion in the tropics: the effects of changing yield and technology. Environmental Research Letters 3: 10.

Gibbs, H., Ruesch, S., Achard, F., Clayton, M., Holmgren, P., Ramankutty, N. and Foley, J. 2010 Tropical forests were the primary sources of new lands 1980-2000. Proceedings of the National Academy of Sciences 107(38): 16732-16737.

Goldemberg, J. 2007 Ethanol for a sustainable energy future. Science 315(5813): 808-810.

Goldemberg, J., Coelho, S.T. and Guardabassi, P. 2008 The sustainability of ethanol production from sugarcane. Energy Policy 36(6): 2086-2097.

Goldemberg, J. and Guardabassi, P. 2009 Are biofuels a feasible option? Energy Policy 37: 10-14.

Government of India 2003 Report of the committee on the development of biofuel.

Grainger, A. 2008 Difficulties in tracking the long term global trend in tropical forest cover. Proceedings of the National Academy of Sciences 105(2): 818-823.

Hall, J., Matos, S., Severino, L. and Beltrao, N. 2009 Brazilian biofuels and social exclusion: established and concentrated ethanol versus emerging and dispersed biodiesel. Journal of Cleaner Production 17.

Hansen, M.C., Townshend, J.R.G., Defries, R.S. and Carroll, M. 2005 Estimation of tree cover using MODIS data at global, continental and regional/ local scales. International Journal of Remote Sensing 26: 4359-4380.

Hansen, M., Stehman, S., Potapov, P., Loveland, T.R., Townshend, J.R.G., DeFries, R., Pittman, K., Arunarwati, B., Stolle, F., Steininger, M. et al. 2008 Humid tropical forest clearing from 2000 to 2005 quantified by using multitemporal and multiresolution remotely sensed data. Proceedings of the National Academy of Sciences 105(27):9439-9442.

Hansen, M.C., Stehman, S.V. and Potapov, P.V 2010 Quantification of global gross forest cover loss. Proceedings of the National Academy of Sciences 107(19): 8650-8653.

Hartley, C.W.C. 1988 The oil palm (E.guineensis Jacq.). $3^{\text {rd }}$ ed. Longman, New York.

Havlík, P., Schneider, U.A., Schmid, E., Böttcher, H., Fritz, S., Skalský, R., Aoko, K., de Cara, S., Kindermann, G., et al. 2010 Global landuse implications of first and second generation biofuel targets. Energy Policy doi.org/10.1016/j. enpol.2010.03.030.

Heller, J. 1996 Promoting the conservation and use of underutilised and neglected crops. 1. Physic nut, Jatropha curcas L. International Plant Genetic Resources Institute, Italy.

Hergoualc'h, K. and Verchot, L. 2011 Stocks and fluxes of carbon associated with land-use change in SE Asian tropical peatlands: a review. In preparation.

Hertel, T.W., Golub, A.A., Jones, A.D., O’Hare, M., Plevein, R.G. and Kammen, D.M. 2010 Effects of US maize ethanol on global land use and greenhouse gas emissions: estimating market mediated responses. Bioscience 60(3): 223-231.

Hileman, J.I., Ortiz, D.S., Bartis, J.T., Wong, H.M., Donohoo, P.E., Weiss, M.A. and Waitz, I.A. 2009 Near-term feasibility of alternative jet fuels. RAND Corporation and the Partnership for Air Transportation Noise and Emissions Reduction, San Diego, CA, USA.

Jasinski, E., Morton, D., DeFries, R., Shimabukuro, Y. and Anderson, L. 2005 Physical landscape correlates of the expansion of mechanised agriculture in Mato Grosso, Brazil. Earth Interactions 9: 1-18.

Jepma, C.J. 1995 Tropical deforestation, a socialeconomic approach. Earthscan, London.

Jongschaap, R., Corré, W., Bindraban, P. and Brandenburg, W. 2007 Claims and facts on Jatropha curcas L. Report 158. Plant Research International and Stichting het Groene Woudt, Wageningen, Netherlands.

Kammen, D.K., Farrel, A.E., Plevin, R.J., Jones, A.D., Nemet, G.F. and Delucchi, M.A. 2007 Energy and greenhouse impacts of biofuels: a framework for analysis. Joint Transportation Research Centre Discussion Paper No. 2007-2. OECD/International Transport Forum.

Kasanga, K.C. 2008 The agrofuel industry in Tanzania: A critical enquiry into challenges and opportunities. OXFAM/LARRRI, Tanzania.

Katerere, F. 2009 Brazil to invest $\$ 6$ billion in Mozambique biofuels, O Pais Says. Bloomberg, 20 November. http://www.bloomberg.com/apps/ news?pid=20601116\&sid=aY3EtpcM2W7c $(20$ January 2010).

KEHATI, Sawit Watch, INRISE, Bogor Agricultural Institute and M.I. Group 2006 Indonesian path toward sustainable energy: A case study of 
developing palm oil as biomass in Indonesia. BothENDS: 44.

Kessler, J.J. 2005 Strategic partnerships for combating forest conversion and the role of financial institutions: learning from action research. In: Ros-Tonen, M. and Dietz, T. (eds) African forests between nature and livelihood resource: interdisciplinary studies in conservation and forest management. Lewiston/Lampeter, Mellen Press.

Kim, H., Kim, S. and Dale, B.E. 2009 Biofuels, land use change and greenhouse gas emissions: some unexplored variables. Environmental Science \& Technology 43: 961-967.

Koh, L.P. and Wilcove, D.S. 2008 Is oil palm agriculture really destroying tropical biodiversity? Conservation Letters 1(2): 60-64.

Lamers, P. 2006 Emerging liquid biofuel markets: A donde va la Argentina? Masters thesis, Environmental Management and Policy. International Institute for Industrial Environmental Economics (IIIEE), Lund University, Sweden.

Lapola, D., Schaldach, R., Alcamo, J., Bondeau, A., Koch, J., Koelking, C. and Priess, J.A. 2010. Indirect land-use changes can overcome carbon savings from biofuels in Brazil. Proceedings of the National Academy of Sciences 107(8): 3388- 3393.

Laurance, W.F., Lovejoy, T.C., Prance, G., Ehrlich, P.R., Mace, G., Raven, P.M., Cheyne, S.M., Bradshaw, C., Masera, O, Frederiksson, G. et al. 2010 An open letter about scientific credibility and the conservation of tropical forests. http:// blogs.nature.com/news/thegreatbeyond/ScientistsLetter-ITS-WGI-Oxley.pdf. (20 February 2011).

Legowo, E.H. 2007 Biofuel development in Indonesia. Presented at USDA Global Conference on Agricultural Biofuels: Research and Economics. 20-22 August, Minneapolis, Minnesota, USA.

Liska, A. and Perrin R. 2009 Indirect land use emissions in the life cycle of biofuels: regulations vs science. Biofuels, Bioproductions and Biorefining 3(3): 318-328.

Londono, L.F. 2007 Informe anual sector azucarero Colombiano. Bogota, Colombia: Presentation to Asocaña (La Asociación de Cultivadores de Caña de Azúcar de Colombia).

Loos, T.G. 2009 Socioeconomic impact of a jatropha project on smallholder farmers in
Mpanda, Tanzania. Masters thesis, University of Hohenheim, Germany.

Lopez, G.P. and Laan, T. 2008 Biofuels, at what cost? Government support for biodiesel in Malaysia. Global Subsidies Initiative (GSI) of the International Institute for Sustainable Development (IISD). Geneva, Switzerland.

MAPA (Brazilian Ministry of Agriculture, Livestock and Supply) 2008 Brazilian Agroenergy Plan 2006-2011.

http://www.embrapa.br/english/publications/ agroenery_miolo.pdf (23 September 2009).

Marklund, L.G. and Schöne, D. 2006 Global assessment of growing stock, biomass and carbon stock. Forest Resource Assessment Program, WO 106/E, United Nations Food and Agriculture Organization, Rome: Matthews, E. and Grainger, A. 2002 Evaluation of FAO's global forest resources assessment from the user perspective. Unasylva 210(53): 42-55.

McCarthy, M. and Buncombe, A. 2005 The rape of the rainforest and the man behind it. Independent News, 20 May. http://www.news.independent. co.uk/world/environment/story.jsp?story $=639814$ (5 July 2010).

Meloni, A., Rudorff, B.F.T., Antoniazzi, L.B., Alves de Aguiar, D., Piedade, M.R. and Adami, M. 2008 Prospects of sugarcane expansion in Brazil: impacts on direct and indirect land use change. Wageningen Academic Publishers, The Netherlands.

Milieudefensie, Friends of the Earth and Sahabat Alam Malaysia 2008 Malaysian palm oil: green gold or green wash? A commentary on the sustainability claims of Malaysia's palm oil lobby, with a special focus on the state of Sarawak.

Ministry of Energy and Mineral Resources Republic Indonesia 2006 Tahun Ini Pemerintah Rencanakan Bangun 11 Pabrik Biodiesel. http:// esdm.go.id/ (21 July 2010).

Ministry of New and Renewable Energy 2009 National Policy on Biofuels. New Delhi, India.

Mongabay 2006 OPEC member Indonesia announces biofuels crash program-11 biodiesel plants. http://news.mongabay.com/ (3 September 2010).

Morton, D.C., DeFries, R.S., Shimabukuro, E., Anderson, L.O., Arai, E., Espirito-Santo, F.d.B., Freita, R. and Morisette, J. 2006 Cropland expansion changes deforestation dynamics in the southern Brazilian Amazon. National Academy of Sciences 103(39): 14637-14641. 
Mother Jones 2009 Ethanol's African land grab. http://motherjones.com/environment/2009/03/ ethanols-african-landgrab (20 January 2010).

Murdiyarso, D., Hergoualc'h, K. and Verchot, L.V. 2010 Opportunities for reducing greenhouse gas emissions in tropical peatlands. Proceedings of the National Academy of Sciences 16(46): 19655-19660.

Nagarajan, M. 2008 Biofuel development in Malaysia. Paper presented at the International Symposium on Agricultural and Biofuel Policy, 25 February, Bangkok, Thailand.

Nepstad, D.C., Stickler, C.M. and Almeida, O.T. 2006 Globalisation of the Amazon soy and beef industries: opportunities for conservation. Conservation Biology 20: 1595-1603.

Nepstad, D., Stickler, C,M., Filho, B.S. and Merry, F. 2008 Interactions among Amazon land use, forests and climate: prospects for a near-term forest tipping point. Philosophical Transactions of the Royal Society of London, Series B, Biological Sciences 363(1498): 1737-1746.

Nepstad D.C., Soares, B.S., Merry, F.D., Lima, A., Moutinho. P., Carter, J., Bowman, M., Cattaneo, A., Rodrigues, H., Schwartzman, S. et al. 2009 The end of deforestation in the Brazilian Amazon. Science 326(5958):1350-1351.

Neves, M.F., Alves, M.J. and Conejero, M.A. 2009 Transnational companies investments in Brazilian agribusiness and agriculture: The case of sugarcane. United Nations Conference on Trade and Development (UNCTAD). São Paolo, Brazil.

Olander, L.P., Gibbs, H.K., Steininger, M., Swenson, J.J. and Murray B.C. 2008 Reference scenarios for deforestation and forest degradation in support of REDD: a review of data and methods. Environmental Research Letters 3025011

Pérez, M.A. and Álvarez, P. 2009 Deuda social ambiental del negocio de la cańa de azúcar en Colombia. ARFO Editores e Impresores Ltda. Bogotá, Colombia.

Persoon, G.A. and Osseweijer, M. 2008 Reflections on the heart of Borneo. Tropenbos Series 24. The Netherlands.

Potter, L. 2008 The oil palm question in Borneo. In: Persson, G.A. and Osseijer, M. (eds.) Reflections on the Heart of Borneo. Tropenbos International. Wageningen, Netherlands.

Pousa, G.P.A.G., Santos, A.L.F. and Suarez, P.A.Z. 2007 History and policy of biodiesel in Brazil. Energy Policy 35: 5393-5398.
Rangel, A., Ramirez, W. and Bentacur, P. 2009 La Palma Africana: Mitos y realidades del conflicto. Bogota, Colombia: Fundacion Seguridad y Democracia.

Ravindranath, N.H., Sathaye, J., Woods, J., Fargione, J., Watson, H., Faaji, A., Makundi, W. and Canadell, P. 2009 GHG implications of land use and land conversion to biofuel crops. In: Howarth, R.W. and Bringezu, S. (eds.) Biofuels: environmental consequences and interactions with changing land use. Report of the International SCOPE Biofuels Project. http://cip.cornell.edu/ biofuels/ (4 July 2010).

Ribeiro, D. and Matavel, N. 2009 jatropha! A socioeconomic pitfall for Mozambique. Justica Ambiental/Uniao Nacional de Camponesese, Mozambique.

Rudel, T.K., Coomes, O.T., Moran, E., Achard, F., Angelsen, A., Cu, J. and Lambin, E. 2005 Forest transitions: toward a global understanding of land use change. Global Environmental Change Part A 15(1): 23-31.

Rutz, D., Thebaud, A., Janssen, R., Segura, S.A., Riegelhaupt, E., Ballesteros, M., Manzanares, P., St James, C., Serafini, D., Coelho, S.T. et al. 2009 Biofuel policies and legislation in Latin America. BIOTOP, Munich, Germany.

Sawaya, M. and Nappo, M. 2009 Etanol de cana-deaçucar: uma solução energética global sob ataque. In: Abramovay, R. (ed.) Biocomustíveis: A energia da controvérsia. SENAC, São Paolo, Brazil.

Sawyer, D. 2008 Climate change, biofuels and eco-social impacts in the Brazilian Amazon and Cerrado. Philosophical Transactions of the Royal Society B: Biological Sciences 363: 1747-1752.

Searchinger, T., Heimlich, R., Houghton, R.A., Dong, F., Elobeid, A., Fabio Tokgoz, S., Hayes, D. and Yu, T.H. 2008 Use of US croplands for biofuels increases greenhouse gases through emissions from land use change. Science 319: 1238-1240.

Searchinger, T.D. 2009 Why uncertainty in modelling indirect land use change from biofuels cannot justify ignoring it. Princeton University and the German Fund of the US. http:// switchboard.nrdc.org/blogs/ngreene/media/ Uncertainty $\% 20$ in $\% 20$ Modeling $\% 20$ and $\% 20$ Indirect \%20Land\%20Use\%20Change\%20-\%20 Searchinger\%20(July\%2014,\%202009).pdf (23 September 2009). 
Setzkorn, K. 2009 Database of biofuel projects in Africa. Council for Scientific and Industrial Research (CSIR), Pretoria, South Africa.

Scales, D., Keil, M., Schmidt, M., Kux, H. and Roberto do Santos, J. 1997 Use of multitemporal ERS-1 SAR data for rainforest monitoring in Acre, Brazil. In: Guyenne, T.D. (ed.) The use and applications of ERS in Latin America. Proceedings of an International Seminar in Vina del Mar, Chile, 25-29 November 1996. Paris: European Space Agency.

Schoneveld, G.C., German, L. and Nutakor, E. (forthcoming) Towards sustainable biofuel development in Ghana: Assessing the effectiveness of the Ghanaian legal and institutional framework. CIFOR, Bogor, Indonesia.

Sheil, D., Casson, A., Meijaard, E., Van Noordwijk, M., Gaskell, J., Sunderland-Groves, J., Wertz, K. and Kanninen, M. 2009 The impact and opportunities of oil palm in southeast Asia: what do we know and what do we need to know? CIFOR Occasional Paper 51. CIFOR, Bogor, Indonesia.

Shimabukuro, Y.S., Duarte, V., Anderson, L.O., Valeriano, D.M., Arai, E., de Freitas, R.M., Rudorff, B.F.T. and Moreira, M.A. 2006 Near real time detection of deforestation in the Brazilian Amazon using MODIS imagery. Revista Ambiente e Agua: An Interdisciplinary Journal of Applied Science 1(11): 37-47.

Sims, R., Taylor, M., Sadler, J. and Mabee, W. 2008 From first to second-generation biofuel technologies, an overview of current industry and RD\&D activities. Organization for Economic Cooperation and Development/International Energy Agency, Paris, France.

Sparovek, G. and Berndes, G. 2008 Sugarcane expansion in Brazil 1996-2006: Land use change and other effects. Presentation at an Expert Workshop on Biofuel and Land Use Change, RSB. 20-21 November, São Paolo, Brazil.

Stokstad, E. 2001 UN report suggests slowed forest losses. Science 291: 2294.

Sulle, E. and Nelson, F. 2009 Biofuels, land access, and rural livelihoods in Tanzania. International Institute for Environment and Development (IIED), London.

Tamil Nadu Agricultural University 2009 Jatropha Position Note: Tamil Nadu Government Project on promotion of jatropha in Tamil Nadu.
Toasa, J. 2009 Colombia: A new ethanol producer on the rise. Economic Research Service, US Department of Agriculture, Washington DC.

Sulle, E. and Nelson, F. 2009 Developing commercial biofuels through securing local livelihoods and land rights. Information Brief, Tanzania Natural Resource Forum, Dar es Salaam, Tanzania.

UNICA (Brazilian Sugarcane Industry Association) 2008 Brazilian sugarcane ethanol: get the facts right and kill the myths. UNICA, São Paolo, Brazil.

UNICA (Brazilian Sugarcane Industry Association) 2009 Sugarcane sector statistics. http://english. unica.com.br/ (4 February 2010).

Vera, J.C. 2009 Experiencias en el desarrollo del programa nacional de biocombustibles: Retos, perspectivas y oportunidades. Colombia, Bogota: Ministerio de Minas y Energia.

Wahid, M.B., Abdullah, S.N.A. and Henson, I.E. 2004 Oil palm: achievements and potential. Proceedings of the 4th International Crop Science Congress, Brisbane, Australia, 26 September -1 October 2004.

Wahid, D.D.M.B. 2010 Overview of the Malaysian Oil Palm Industry 2009. Malaysia Palm Oil Board.

Wang, L., Sousa, W.P., Gong, P. and Biging, G.S. 2004 Comparison of IKONOS and QUICKBIRD images for mapping mangrove species on the Caribbean coast of Panama. Remote Sensing of Environment 91: 432-440.

WBGU (German Advisory Council on Global Change) 2008 Future bioenergy and sustainable land use. Earthscan, London.

WI (Worldwatch Institute) 2007 Biofuels for transport: global potential and implications for sustainable energy and agriculture. Earthscan, London.

Wilkinson, J. and Herrera, S. 2010 Biofuels in Brazil: debates and impacts. Journal of Peasant Studies 37(4): 749-768.

World Bank 2008 Commodity Price Data.http:// siteresources.worldbank.org/INTDAILYPROSPECTS/ Resources/Pnk_1008.pdf. (6 February 2010).

World Growth (passim) http://www.worldgrowth. org/palmoil/.

World Growth 2009 Palm oil: the sustainable oil. A Report by World Growth. September 2009. http://www.worldgrowth.org/assets/files/Palm_ Oil.pdf (8 July 2010). 
Wright, A.M. 2009 Sustainability and agriculture in the state of Mato Grosso. Brazil.

Institute, Woodrow Wilson International Centre for Scholars, Washington DC.

WWF (World Wide Fund for Nature) 2009 Biofuel industry study, Tanzania: an assessment of the current condition. WWF, Tanzania.

Zahabu, E. 2008 Sinks and sources: a strategy to involve forest communities in Tanzania in global climate policy. PhD thesis, University of Twente, The Netherlands.

Zhan, X., Sohlberg, R.A., Townshend, J.R.G., DiMiceli, C., Carroll, M.L., Eastman, J.C., Hansen, M.C. and DeFries, R.S. 2002 Detection of land cover changes using MODIS 250m data. Remote Sensing of Environment 83: 336-350. 


\section{Appendix 1}

\section{Characteristics and global suitability maps of the main biofuel feedstocks}

\section{Characteristics of bioethanol and biodiesel feedstocks}

\begin{tabular}{|c|c|}
\hline Bioethanol feedstock & Characteristics \\
\hline Sugarcane & $\begin{array}{l}\text { Native to tropical regions, it is a semiperennial crop and can be harvested 5-10 years after planting. } \\
\text { Sugarcane has high photosynthetic efficiency. }\end{array}$ \\
\hline Sugar beet & An annual crop suited to temperate and subtropical climates. \\
\hline Maize & $\begin{array}{l}\text { An annual crop, domesticated in Mesoamerica which subsequently spread throughout the world. } \\
\text { Maize adapts well to different climatic conditions. }\end{array}$ \\
\hline Wheat & $\begin{array}{l}\text { Originated in the area known as the Fertile Crescent in western Asia; an annual crop suited to } \\
\text { temperate climate. }\end{array}$ \\
\hline Sorghum & $\begin{array}{l}\text { A grain commonly used for food and fodder, cultivated in warmer and drier climates worldwide. } \\
\text { Different species are grown in tropical and subtropical regions of all continents. }\end{array}$ \\
\hline Barley & $\begin{array}{l}\text { A cereal grain derived from the annual grass Hordeum vulgare, widely adaptable and popular in } \\
\text { temperate climates where it is grown as a summer crop; also in tropical climates, where it is grown } \\
\text { as winter crop. }\end{array}$ \\
\hline Switch grass & $\begin{array}{l}\text { Also known as Panicum virgatum. It is a hardy, deep-rooted, perennial grass native to North } \\
\text { America. }\end{array}$ \\
\hline Biodiesel feedstock & Characteristics \\
\hline Oil palma & $\begin{array}{l}\text { Grown in tropical climates within } 20 \text { degrees of the equator, mainly Malaysia, Indonesia and } \\
\text { west Africa. It takes } 5 \text { years from planting to first fruiting. Once established, it crops continuously } \\
\text { throughout the year. }\end{array}$ \\
\hline Jatropha Jatrophab & $\begin{array}{l}\text { A small to medium height tree (5-7m maximum) of the Euphorbiaceae genus. Its origin is Central } \\
\text { America; however, it has been grown in Africa and other parts of the world for over } 100 \text { years } \\
\text { (Heller 1996). It can be grown on marginal lands and is said to be drought tolerant. }\end{array}$ \\
\hline Rapeseed & $\begin{array}{l}\text { Grows farther north than any other major oil producing plant. Rapeseed for oil production occurs } \\
\text { mainly in the UK and Europe and Canada (where it is called canola). It is an annual, winter to spring } \\
\text { crop, suited to temperate and subtropical climates. }\end{array}$ \\
\hline Sunflower seed & $\begin{array}{l}\text { Sunflower is annual summer crop, suitable to temperate and subtropical climates. Biofuel yields: } \\
630-1700 \text { litres per ha. }\end{array}$ \\
\hline Castor bean & $\begin{array}{l}\text { The castor oil plant-Ricinus communis-is an annual crop. The plant is native to the Ethiopian } \\
\text { region of tropical east Africa and naturalised in tropical and warm temperate regions throughout } \\
\text { the world. }\end{array}$ \\
\hline Soya & $\begin{array}{l}\text { Soya is an annual plant, suitable to climates with hot summers, best growing temperature } 20-30 \\
\text { degrees. It is grown extensively in the USA, South America, and China. Soya oil is the world's largest } \\
\text { source of vegetable oil. }\end{array}$ \\
\hline
\end{tabular}

a For additional material on oil palm, see Appendix 3.

b For additional material on jatropha and a global jatropha distribution map, see Appendix 3. 

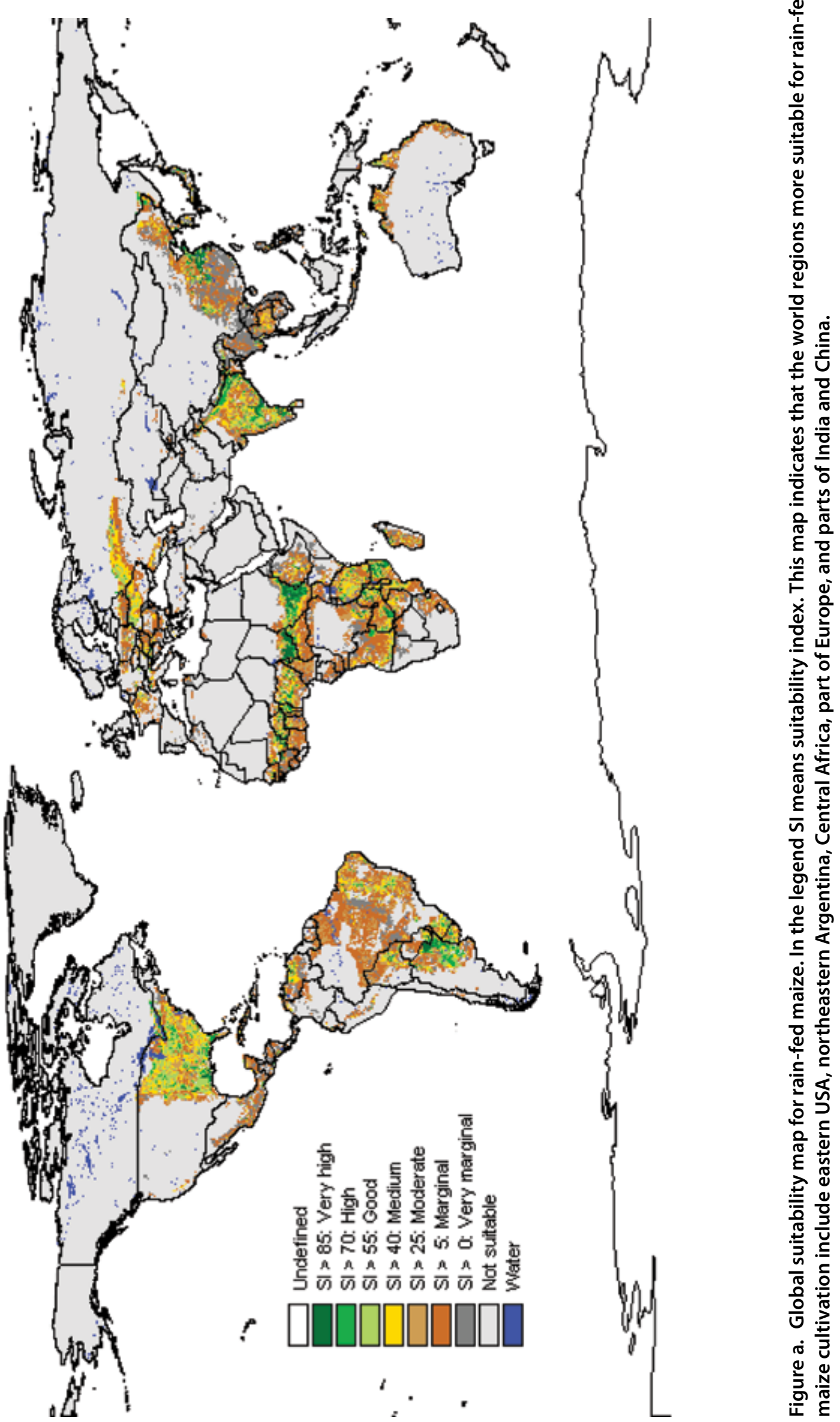


\section{Suitability Maps}

Suitability maps for the major biofuel feedstocks have been produced at the global level in recent years. In this appendix, we present the results of Fischer et al. 2002. Each global map has approximately 2.2 million grid cells and was created using a suitability index (SI) which reflects the suitability makeup of a particular grid cell to each particular feedstock. The SI was calculated by the following equation:

$\mathrm{SI}=\mathrm{VS} \times 0.9+\mathrm{S} \times 0.7+\mathrm{MS} \times 0.5+\mathrm{mS} \times 0.3$

In which:

VS : the portion of the grid cell with attainable yields that are $80 \%$ or more of the maximum potential yield;

$\mathrm{S}$ : the portion of the grid cell with attainable yields that are $60-80 \%$ of the maximum potential yield;

MS : the portion of the grid cell with attainable yields that are $40-60 \%$ of the maximum potential yield;

$\mathrm{mS}$ : the portion of the grid cell with attainable yields that are $20-40 \%$ of the maximum potential yield. 

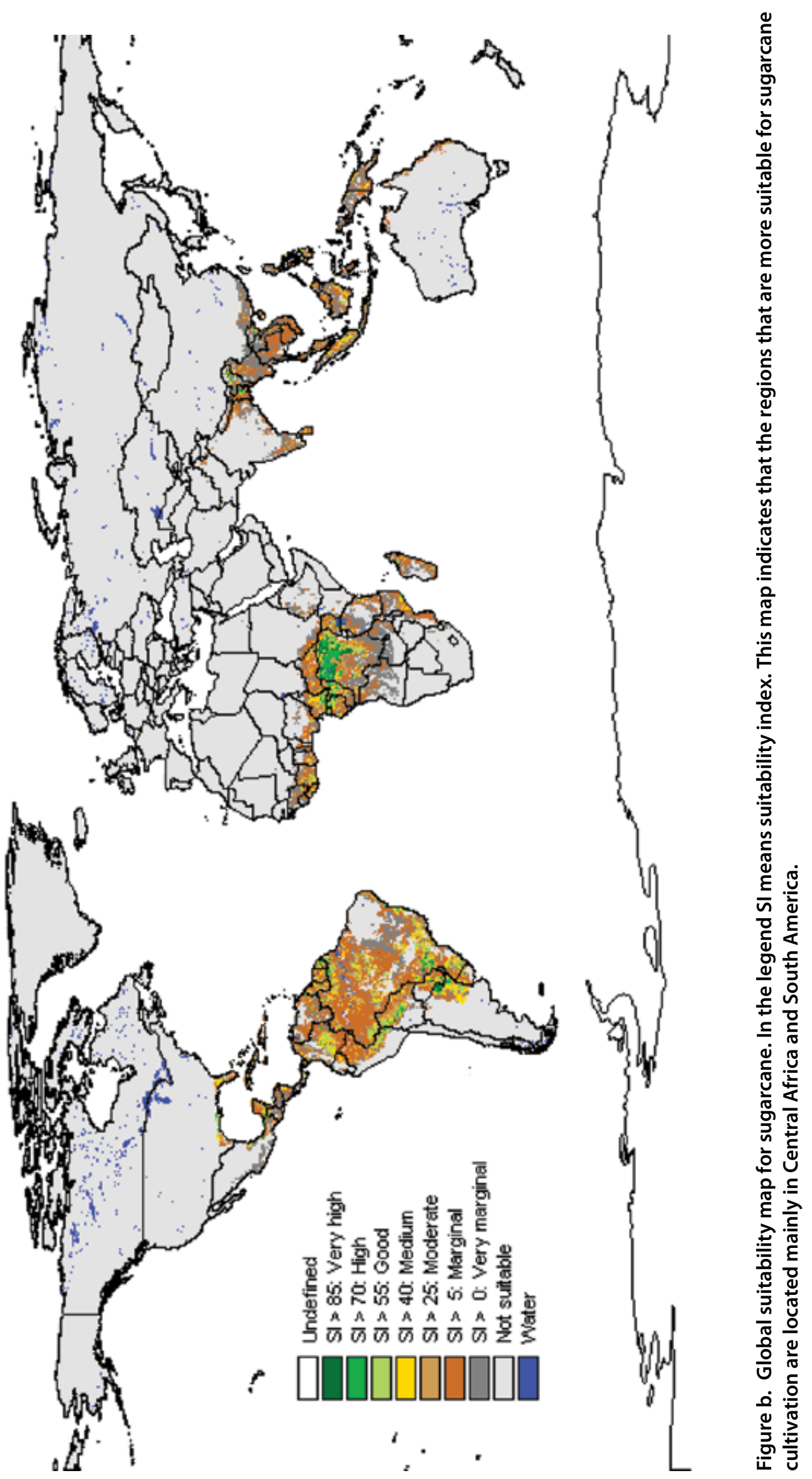


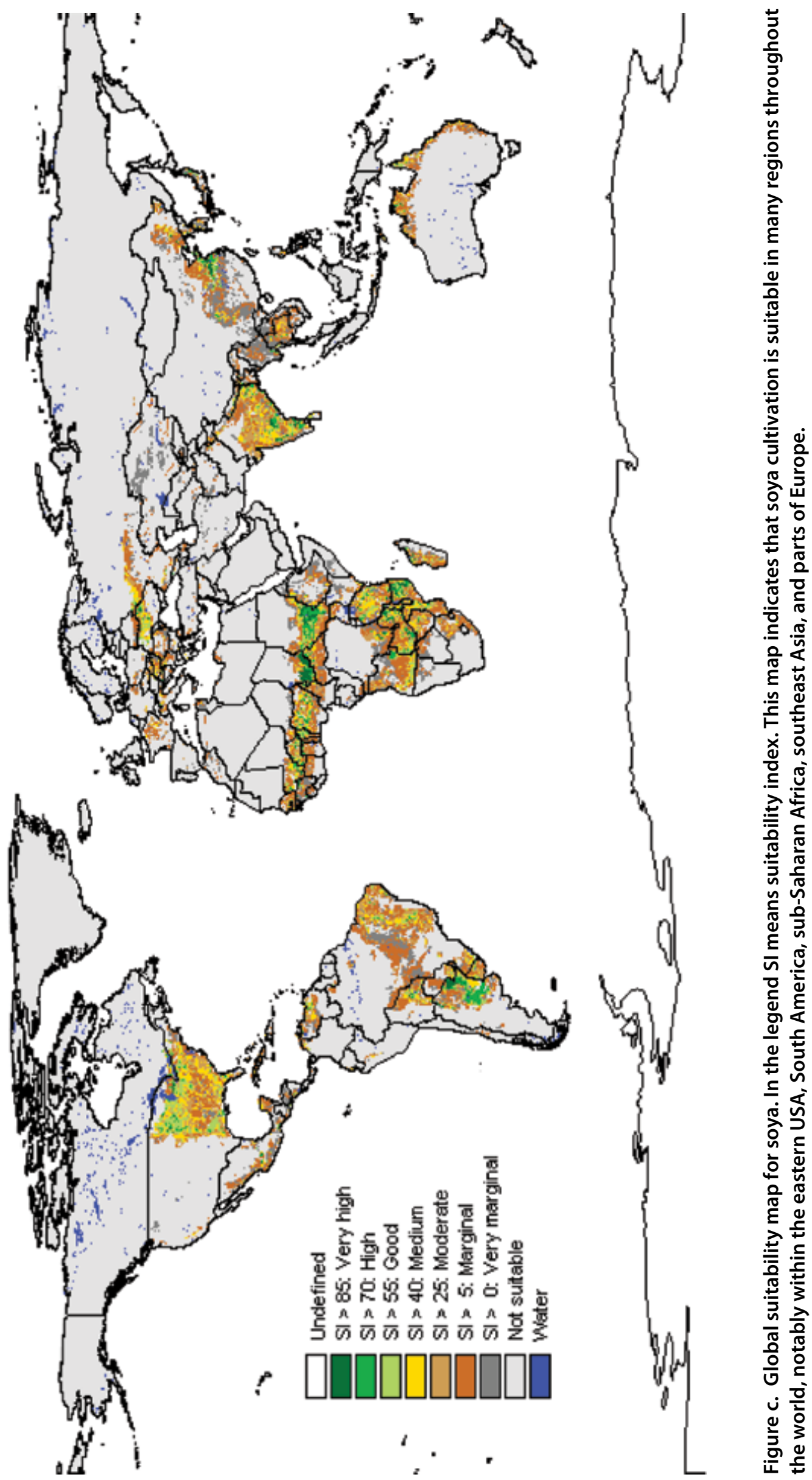




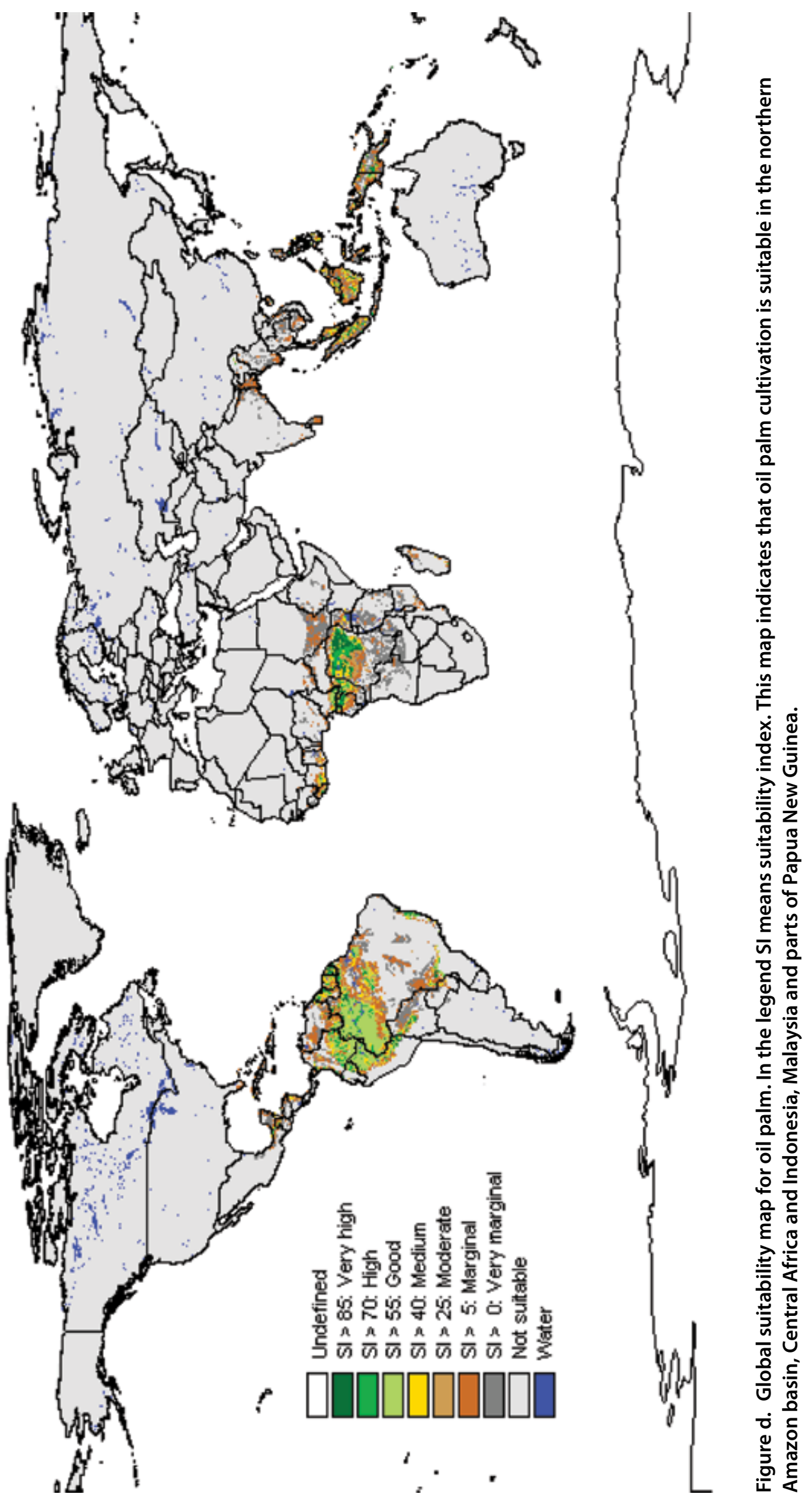




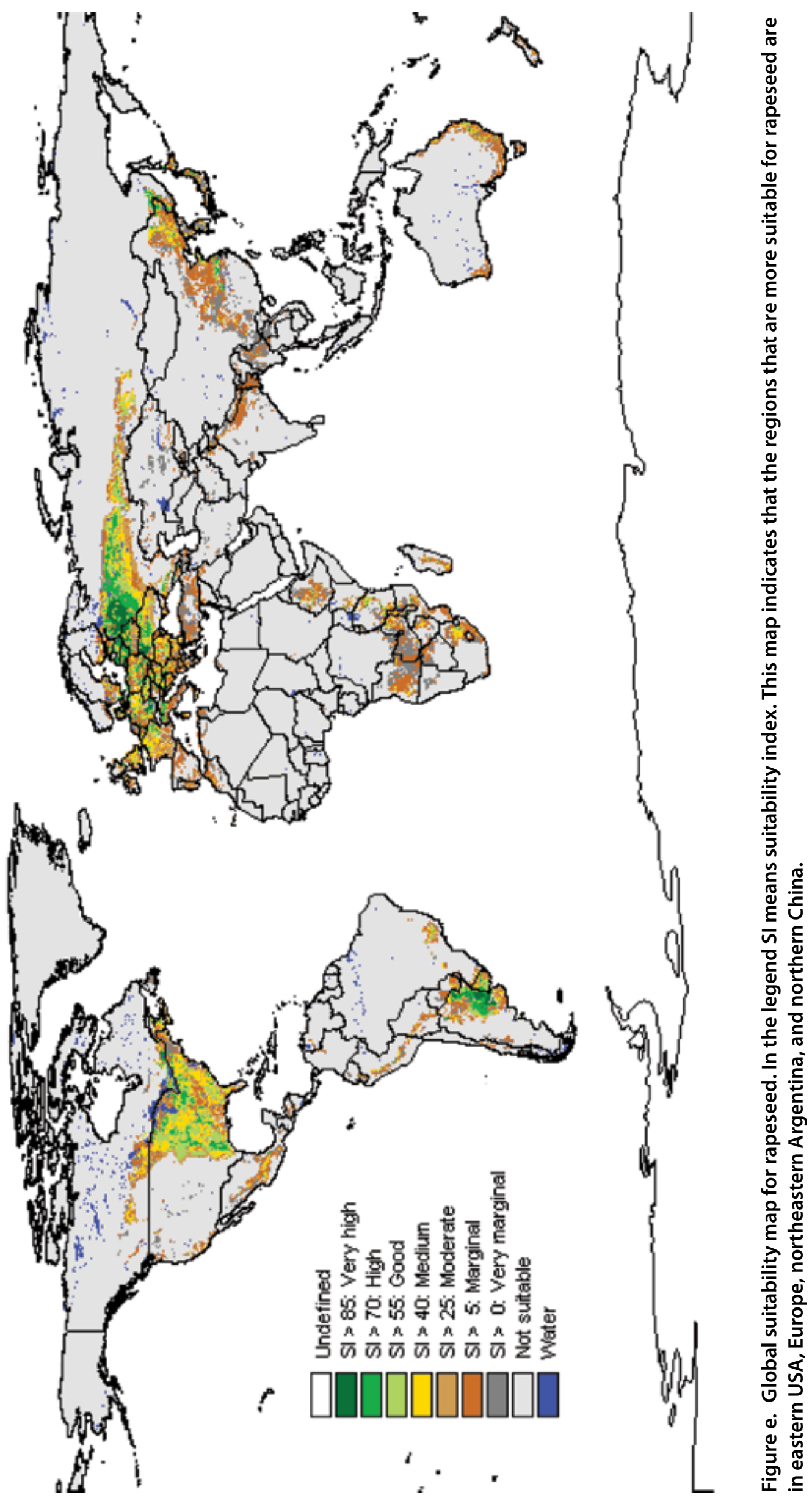



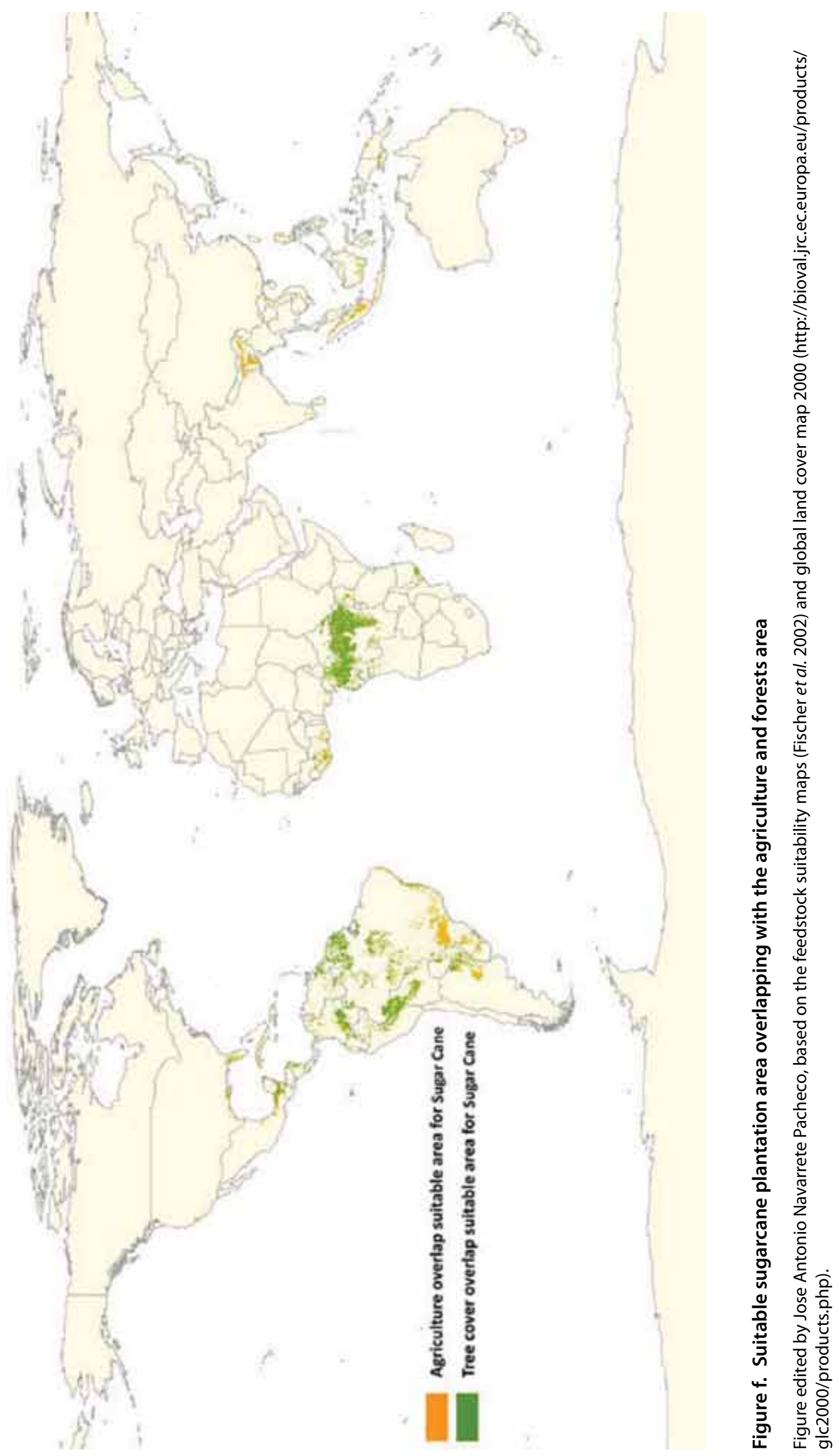


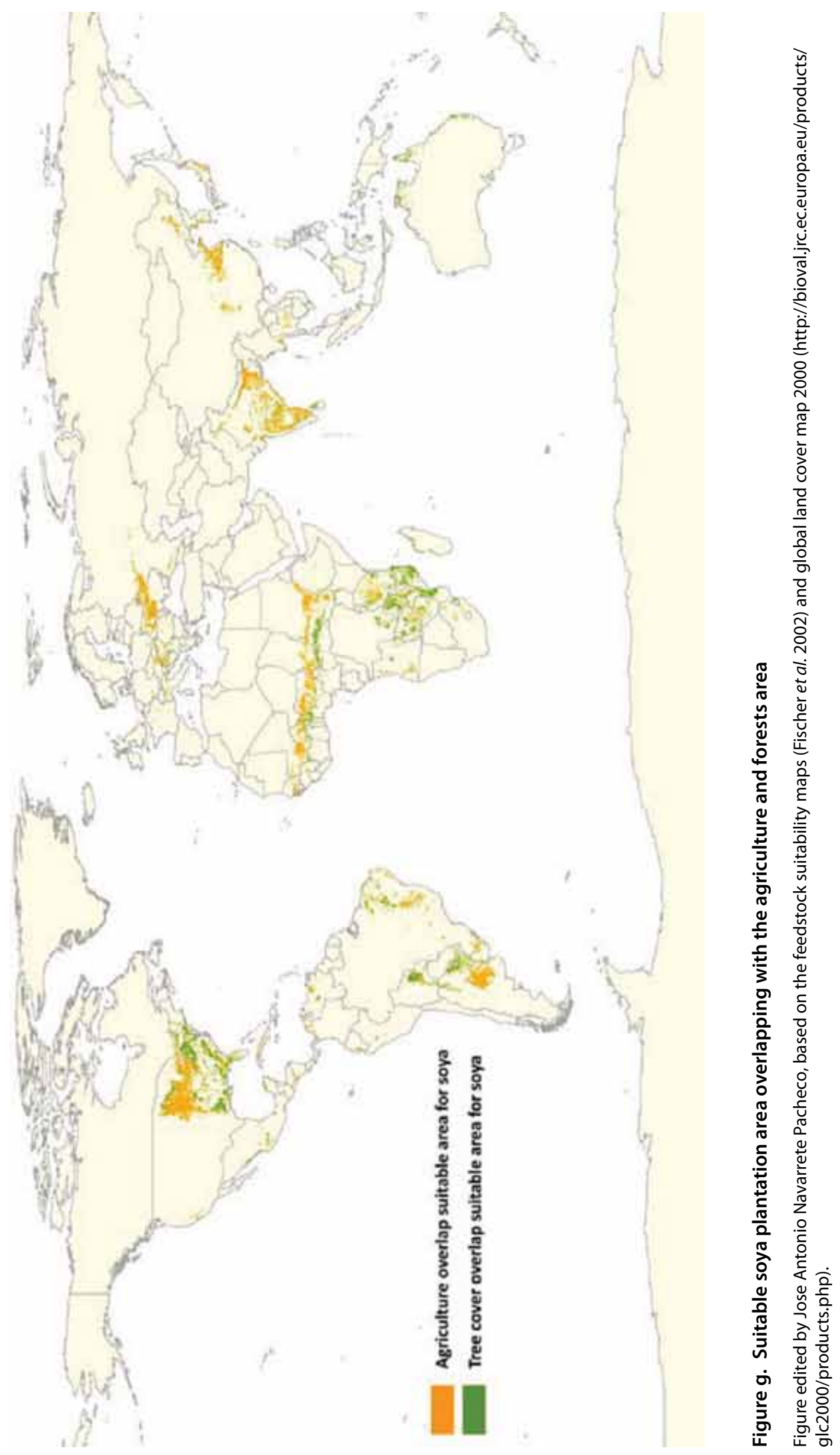



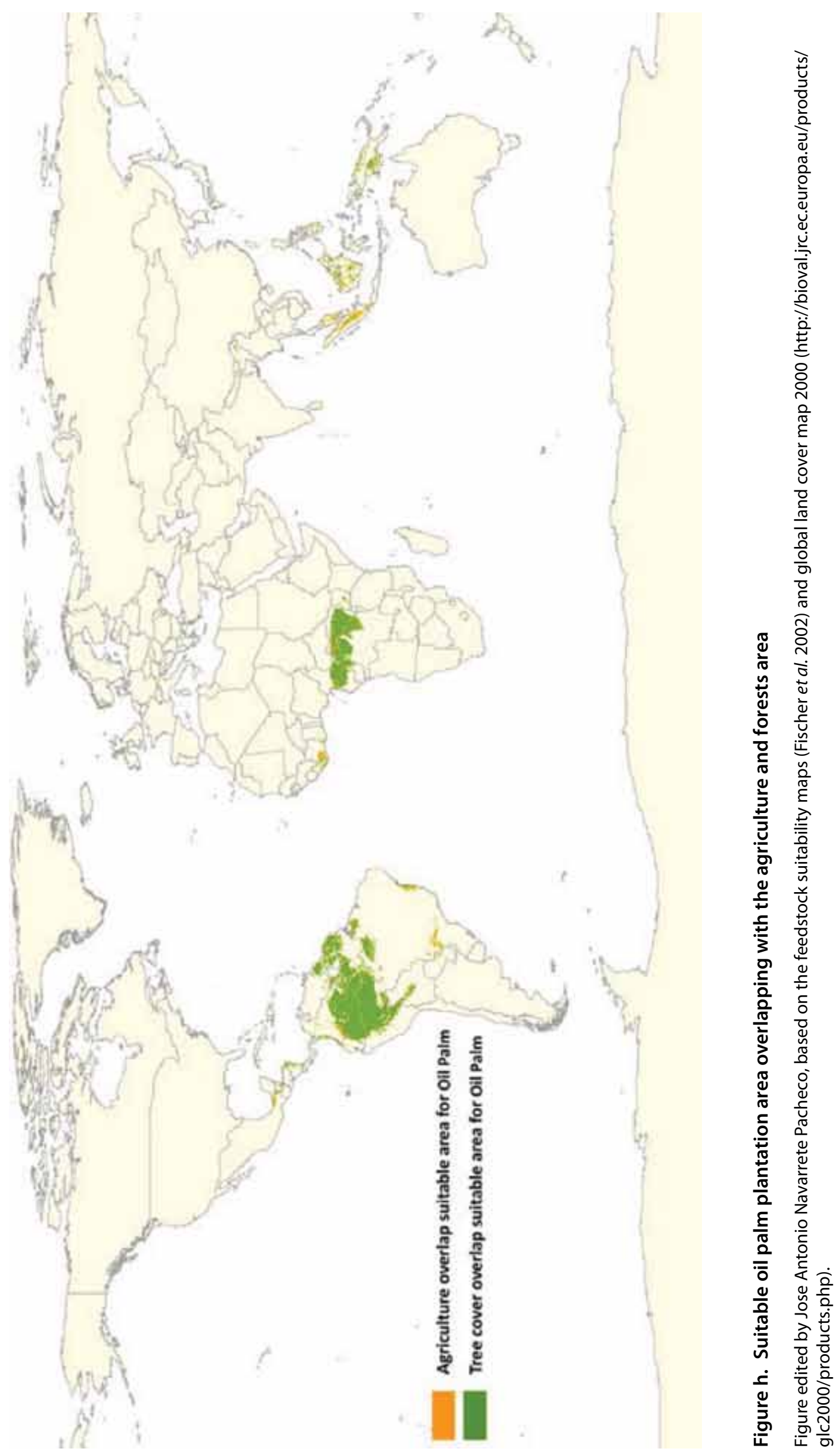


\section{Appendix 2}

\section{World biofuel plants for selected developing countries by country}

\begin{tabular}{|c|c|c|c|c|c|}
\hline Plant No. & City & $\begin{array}{l}\text { Capacity } \\
\text { (litres per year) }\end{array}$ & $\begin{array}{l}\text { Plant location state } \\
\text { (Figure i) }\end{array}$ & Type of biofuel & Feedstock \\
\hline 1 & Aracatuba & 151-283 million & São Paolo & ethanol & \\
\hline 2 & Mamanguape & $<151$ million & Paraiba (PB) & ethanol & \\
\hline 3 & Rio Largo & $<151$ million & Alagoas (AL) & ethanol & \\
\hline 4 & $\begin{array}{l}\text { São Raimundo Das } \\
\text { Mangabeiras }\end{array}$ & $<151$ million & Maranhão (MA) & ethanol & \\
\hline 5 & Nanuque & $<151$ million & Minas Gerais (MG) & ethanol & \\
\hline 6 & Orasco & $<151$ million & São Paolo (SP) & ethanol & \\
\hline 7 & Junqueirópolis & $<151$ million & São Paolo (SP) & ethanol & \\
\hline 8 & Anicuns & $<151$ million & Goiás (GO) & ethanol & \\
\hline 9 & Santo Antonio Do Aracangua & $<151$ million & São Paolo (SP) & ethanol & \\
\hline 10 & Barra Do Bugres & $<151$ million & Mato Grosso & ethanol & \\
\hline 11 & Sindrolândia & $<151$ million & Espirito Santo & ethanol & \\
\hline 12 & Icem & $<151$ million & São Paolo (SP) & ethanol & \\
\hline 13 & Sindrolândia & $<151$ million & Espirito Santo & ethanol & \\
\hline 14 & Rio Largo & $<151$ million & Alagoas (AL) & ethanol & \\
\hline 15 & Camutanga & $<151$ million & Pernambuco (PE) & ethanol & \\
\hline 16 & Porto Calvo & $<151$ million & Alagoas (AL) & ethanol & \\
\hline 17 & Queiroz & $<151$ million & São Paolo (SP) & ethanol & \\
\hline 18 & Clementina & $<151$ million & São Paolo (SP) & ethanol & \\
\hline 19 & Marechal Deodoro & $<151$ million & Alagoas (AL) & ethanol & \\
\hline 20 & Sertãozinho & $<151$ million & São Paolo (SP) & ethanol & \\
\hline 21 & Dois Corregos & $<151$ million & São Paolo (SP) & ethanol & \\
\hline 22 & Carmo Do Rio Verde & 151-283 million & Goiás (GO) & ethanol & \\
\hline 23 & Rio Verde & $<151$ million & Goiás (GO) & ethanol & \\
\hline 24 & Orindiúva & 151-283 million & São Paolo (SP) & ethanol & \\
\hline 25 & Nuporanga & $<151$ million & São Paolo (SP) & ethanol & \\
\hline 26 & Giasa & $<151$ million & Goiás (GO) & ethanol & \\
\hline 27 & Ibaiti & $<151$ million & Paraná & ethanol & \\
\hline 28 & Sud Mennucci & $<151$ million & São Paolo (SP) & ethanol & \\
\hline 29 & Platina & 151-283 million & São Paolo (SP) & ethanol & \\
\hline 30 & Jundiá & $<151$ million & Alagoas (AL) & ethanol & \\
\hline 31 & Promissão & 151-283 million & São Paolo (SP) & ethanol & \\
\hline 32 & Andradina & 151-283 million & São Paolo (SP) & ethanol & \\
\hline 33 & Goianésia & $<151$ million & Goiás (GO) & ethanol & \\
\hline 34 & Presidente Figueiredo & $<151$ million & Amazonas (AM) & ethanol & \\
\hline 35 & Vitória De Santo Antão & $<151$ million & Alagoas (AL) & ethanol & \\
\hline 36 & União Dos Palmares & $<151$ million & Alagoas (AL) & ethanol & \\
\hline 37 & Campestre Do Maranhão & $<151$ million & Maranhão (MA) & ethanol & \\
\hline 38 & Morro Agudo & 151-283 million & São Paolo (SP) & ethanol & \\
\hline 39 & São Miguel Dos Campos & $<151$ million & Alagoas (AL) & ethanol & \\
\hline 40 & Miranpolis & $<151$ million & São Paolo (SP) & ethanol & \\
\hline 41 & Vista Alegre Do Alto & $<151$ million & São Paolo (SP) & ethanol & \\
\hline 42 & Maracaí & $<151$ million & São Paolo (SP) & ethanol & \\
\hline 43 & Tarumã & $<151$ million & São Paolo (SP) & ethanol & \\
\hline 44 & Brotas & $<151$ million & São Paolo (SP) & ethanol & \\
\hline
\end{tabular}




\begin{tabular}{|c|c|c|c|c|c|}
\hline Plant No. & City & $\begin{array}{l}\text { Capacity } \\
\text { (litres per year) }\end{array}$ & $\begin{array}{l}\text { Plant location state } \\
\text { (Figure i) }\end{array}$ & Type of biofuel & Feedstock \\
\hline 45 & Penedo & $<151$ million & Ceará (CE) & ethanol & \\
\hline 46 & Campo Alegre & $<151$ million & Alagoas (AL) & ethanol & \\
\hline 47 & Joaquim Nabuco & $<151$ million & Pernambuco (PE) & ethanol & \\
\hline 48 & Engenheiro Beltrão & $<151$ million & Paraná & ethanol & sugarcane \\
\hline 49 & Perobal & $<151$ million & São Paolo (SP) & ethanol & sugarcane \\
\hline 50 & Nova Alvorada Do Sul & $<151$ million & Mato Grosso Do Sur (MS) & ethanol & \\
\hline 51 & Ipojuca & $<151$ million & Pernambuco (PE) & ethanol & \\
\hline 52 & Caaporã & $<151$ million & Pernambuco (PE) & ethanol & \\
\hline 53 & Canapolis & $<151$ million & Goiás (GO) & ethanol & \\
\hline 54 & Boca Da Mata & $<151$ million & Alagoas (AL) & ethanol & \\
\hline 55 & Guararapes & $<151$ million & São Paolo (SP) & ethanol & \\
\hline 56 & Alto Alegre & $<151$ million & Roraima (RO) & ethanol & \\
\hline 57 & Presidente Prudente & $<151$ million & São Paolo (SP) & ethanol & \\
\hline 58 & Valparaiso & 151-283 million & São Paolo (SP) & ethanol & \\
\hline 59 & Cidade Gaucha & $<151$ million & Paraná & ethanol & \\
\hline 60 & Capivari & $<151$ million & São Paolo (SP) & ethanol & \\
\hline 61 & Cosmópolis & $<151$ million & São Paolo (SP) & ethanol & \\
\hline 62 & Guaira & $<151$ million & Paraná & ethanol & \\
\hline 63 & São Joaquim Da Barra & $<151$ million & São Paolo (SP) & ethanol & \\
\hline 64 & Araporã & $<151$ million & Minas Gerais (MG) & ethanol & \\
\hline 65 & Bandeirantes & $<151$ million & Mato Grosso Do Sur (MS) & ethanol & \\
\hline 66 & Batatais & $<151$ million & São Paolo (SP) & ethanol & \\
\hline 67 & Pontal & $<151$ million & São Paolo (SP) & ethanol & \\
\hline 68 & Pontal & $<151$ million & São Paolo (SP) & ethanol & \\
\hline 69 & Pirangi & $<151$ million & Ceará (CE) & ethanol & \\
\hline 70 & Guariba & 382-567 million & Rio Grande Do Sur (RS) & ethanol & \\
\hline 71 & Primavera & $<151$ million & Bahia (BA) & ethanol & \\
\hline 72 & Delta & $<151$ million & Minas Gerais (MG) & ethanol & \\
\hline 73 & Conceição Das Alagoas & $<151$ million & Minas Gerais (MG) & ethanol & \\
\hline 74 & Catanduva & $<151$ million & São Paolo (SP) & ethanol & \\
\hline 75 & Paraguaçu Paulista & $<151$ million & São Paolo (SP) & ethanol & \\
\hline 76 & Alagoas & 151-283 million & Alagoas (AL) & ethanol & \\
\hline 77 & Costa Pinto & 382-567 million & Minas Gerais (MG) & ethanol & \\
\hline 78 & Leme & $<151$ million & São Paolo (SP) & ethanol & \\
\hline 79 & Barra Bonita & 571-757 million & São Paolo (SP) & ethanol & \\
\hline 80 & Araçatuba & 571-757 million & São Paolo (SP) & ethanol & \\
\hline 81 & Andradina & $<151$ million & São Paolo (SP) & ethanol & \\
\hline 82 & lbate & $<151$ million & São Paolo (SP) & ethanol & \\
\hline 83 & Tapejara & $<151$ million & Paraná & ethanol & \\
\hline 84 & Maringá & $<151$ million & Paraná & ethanol & \\
\hline 85 & Ivaté & $<151$ million & Paraná & ethanol & \\
\hline 86 & Paranacity & $<151$ million & Paraná & ethanol & \\
\hline 87 & Bariri & $<151$ million & São Paolo (SP) & ethanol & \\
\hline 88 & Jau & $<151$ million & São Paolo (SP) & ethanol & \\
\hline 89 & Estivas & $<151$ million & Alagoas (AL) & ethanol & \\
\hline 90 & Alambari & $<151$ million & Minas Gerais (MG) & ethanol & \\
\hline 91 & Goianésia & $<151$ million & Goiás (GO) & ethanol & \\
\hline 92 & Coruripe & $<151$ million & Alagoas (AL) & ethanol & \\
\hline 93 & Borá & $<151$ million & Maranhão (MA) & ethanol & \\
\hline 94 & Ipaussu & $<151$ million & São Paolo (SP) & ethanol & \\
\hline 95 & Urucania & $<151$ million & Minas Gerais (MG) & ethanol & \\
\hline 96 & Igarapava & 287-378 million & São Paolo (SP) & ethanol & \\
\hline
\end{tabular}




\begin{tabular}{|c|c|c|c|c|c|}
\hline Plant No. & City & $\begin{array}{l}\text { Capacity } \\
\text { (litres per year) }\end{array}$ & $\begin{array}{l}\text { Plant location state } \\
\text { (Figure i) }\end{array}$ & Type of biofuel & Feedstock \\
\hline 97 & Lagoa Da Prata & $<151$ million & Minas Gerais (MG) & ethanol & \\
\hline 98 & Maracai & $<151$ million & São Paolo (SP) & ethanol & \\
\hline 99 & Maracaju & $<151$ million & Mato Grosso Do Sur (MS) & ethanol & \\
\hline 100 & Itapemirim & $<151$ million & ES (coast) & ethanol & \\
\hline 101 & Penedo & $<151$ million & Ceará (CE) & ethanol & \\
\hline 102 & Rio Brilhante & $<151$ million & Mato Grosso Do Sur (MS) & ethanol & \\
\hline 103 & Ibirarema & $<151$ million & São Paolo (SP) & ethanol & \\
\hline 104 & Lagoa De Itaenga & $<151$ million & Pernambuco (PE) & ethanol & \\
\hline 105 & Sebastianópolis Do Sul & $<151$ million & São Paolo (SP) & ethanol & \\
\hline 106 & Rafard & 151-283 million & São Paolo (SP) & ethanol & \\
\hline 107 & Paraiso & $<151$ million & Santa Catarina (SC) & ethanol & \\
\hline 108 & Jaboticabal & $<151$ million & São Paolo (SP) & ethanol & \\
\hline 109 & Nova Europa & $<151$ million & São Paolo (SP) & ethanol & \\
\hline 110 & Rio Das Pedras & $<151$ million & São Paolo (SP) & ethanol & \\
\hline 111 & Novo Horizonte & $<151$ million & São Paolo (SP) & ethanol & \\
\hline 112 & Motuca & $<151$ million & São Paolo (SP) & ethanol & \\
\hline 113 & Santa Rita Do Passa Quatro & $<151$ million & São Paolo (SP) & ethanol & \\
\hline 114 & Pirajuba & $<151$ million & Pernambuco (PE) & ethanol & \\
\hline 115 & Jaboticabal & $<151$ million & São Paolo (SP) & ethanol & \\
\hline 116 & Catanduva & $<151$ million & São Paolo (SP) & ethanol & \\
\hline 117 & Santa Rita & $<151$ million & Paraiba (PB) & ethanol & \\
\hline 118 & Igarassu & $<151$ million & Pernambuco (PE) & ethanol & \\
\hline 119 & Rio Das Pedras & $<151$ million & São Paolo (SP) & ethanol & \\
\hline 120 & São Manoel & $<151$ million & Rio Grande Do Sur (RS) & ethanol & \\
\hline 121 & Pradópolis & $<151$ million & São Paolo (SP) & ethanol & \\
\hline 122 & Maceió & $<151$ million & Alagoas (AL) & ethanol & \\
\hline 123 & Capinopolis & $<151$ million & Minas Gerais (MG) & ethanol & \\
\hline 124 & Itapaci & $<151$ million & Goiás (GO) & ethanol & \\
\hline 125 & Baia Formosa & $<151$ million & Bahia (BA) & ethanol & \\
\hline 126 & Cortês & $<151$ million & Pernambuco (PE) & ethanol & \\
\hline 127 & Araraquara & $<151$ million & São Paolo (SP) & ethanol & \\
\hline
\end{tabular}

\section{Colombia}

\begin{tabular}{clllll}
\hline Plant No. & City & $\begin{array}{l}\text { Capacity } \\
\text { (litres per year) }\end{array}$ & $\begin{array}{l}\text { Plant location state } \\
\text { (Figure i) }\end{array}$ & Type of biofuel & Feedstock \\
\hline 1 & Palmira & $<151$ million & & ethanol & sugarcane \\
\hline
\end{tabular}

\section{Indonesia}

\begin{tabular}{|c|c|c|c|c|c|}
\hline Plant No. & City & $\begin{array}{l}\text { Capacity } \\
\text { (litres per year) }\end{array}$ & $\begin{array}{l}\text { Plant location } \\
\text { state (Figure i) }\end{array}$ & Type of biofuel & Feedstock \\
\hline 1 & Jakarta & $<151$ million & & biodiesel & jatropha \\
\hline 2 & & $<151$ million & & biodiesel & palm oil \\
\hline 3 & Tamlag Valley & $<151$ million & & ethanol & sugarcane \\
\hline 4 & & $<151$ million & & biodiesel & palm oil \\
\hline 5 & Jakarta & $<151$ million & & biodiesel & jatropha jatropha \\
\hline 6 & & $<151$ million & & biodiesel & multiple feedstocks \\
\hline 7 & & $<151$ million & & biodiesel & palm oil \\
\hline 8 & & $<151$ million & & biodiesel & palm oil \\
\hline 9 & S, Carlos City & $<151$ million & & ethanol & sugarcane \\
\hline 10 & Dumai & 382-567 million & & biodiesel & palm oil \\
\hline 11 & Riau & 287-378 million & & biodiesel & palm oil \\
\hline
\end{tabular}


India

\begin{tabular}{|c|c|c|c|c|c|}
\hline Plant No. & City & $\begin{array}{l}\text { Capacity } \\
\text { (litres per year) }\end{array}$ & $\begin{array}{l}\text { Plant location state } \\
\text { (Figure i) }\end{array}$ & Type of biofuel & Feedstock \\
\hline 1 & New Delhi & $<151$ million & & ethanol & \\
\hline 2 & Aurangabad & $<151$ million & & ethanol & \\
\hline 3 & Mumbai & $<151$ million & & ethanol & sugarcane \\
\hline 4 & Mumbai & $<151$ million & & ethanol & \\
\hline 5 & Secunderabad & $<151$ million & & ethanol & \\
\hline 6 & Aurangabad & $<151$ million & & ethanol & \\
\hline 7 & Kakinada & $<151$ million & & ethanol/biodiesel & soya \\
\hline 8 & Kolhalpur & $<151$ million & & ethanol & \\
\hline 9 & Pune & $<151$ million & & ethanol & \\
\hline 10 & Maharashtra & $<151$ million & & ethanol & \\
\hline 11 & PALI & $<151$ million & & biodiesel & multiple feedstock \\
\hline 12 & PALI & $<151$ million & & biodiesel & multiple feedstock \\
\hline 13 & Bhopal & $<151$ million & & ethanol & sugarcane \\
\hline 14 & Mumbai & $<757$ million & & biodiesel & multiple feedstock \\
\hline 15 & Hyderabad & $<151$ million & & ethanol & corn \\
\hline 16 & Herwad & $<151$ million & & ethanol & corn \\
\hline 17 & Andhra Pradesh & $<151$ million & & biodiesel & jatropha jatropha \\
\hline 18 & Uttar Pradesh & $<151$ million & & ethanol & \\
\hline 19 & Islampur & $<151$ million & & ethanol & \\
\hline
\end{tabular}

\section{Malaysia}

\begin{tabular}{|c|c|c|c|c|c|}
\hline Plant No. & City & $\begin{array}{l}\text { Capacity } \\
\text { (litres per year) }\end{array}$ & $\begin{array}{l}\text { Plant location state } \\
\text { (Figure i) }\end{array}$ & Type of biofuel & Feedstock \\
\hline 1 & Johor & $<151$ million & Jahor Bahru & biodiesel & palm oil \\
\hline 2 & Kuching Sarawak & $<151$ million & & biodiesel & palm oil \\
\hline 3 & Selangor & $<151$ million & & biodiesel & palm oil \\
\hline 4 & Kuantan Port & $<151$ million & & biodiesel & \\
\hline 5 & Kuantan Port & $<151$ million & & biodiesel & multiple feedstocks \\
\hline 6 & Johor & $<151$ million & & biodiesel & palm oil \\
\hline 7 & $\begin{array}{l}\text { Teluk Panglima Garang, } \\
\text { Banting }\end{array}$ & $<151$ million & & biodiesel & palm oil \\
\hline 8 & East Estate, Carey Island & $<151$ million & & biodiesel & palm oil \\
\hline 9 & Lumut & 151-283 million & & biodiesel & palm oil \\
\hline 10 & Johor & $<151$ million & & biodiesel & palm oil \\
\hline
\end{tabular}

\section{South Africa}

\begin{tabular}{cllll}
\hline Plant No. & City & $\begin{array}{l}\text { Capacity } \\
\text { (litres per year) }\end{array}$ & $\begin{array}{l}\text { Plant location state } \\
\text { (Figure i) }\end{array}$ & $\begin{array}{l}\text { Type of biofuel } \\
\text { Feedstock }\end{array}$ \\
\hline 1 & Johannesburg & $<151$ million & biodiesel & vegetable oil \\
2 & Johannesburg & $<151$ million & biodiesel & multiple feedstock \\
3 & Durban & $<151$ million & ethanol & sugarcane \\
4 & Johannesburg & $<151$ million & biodiesel & jatropha \\
5 & Polokwane & $<151$ million & ethanol & corn \\
6 & Bothaville & $<151$ million & ethanol & molasses \\
7 & Durban & $<151$ million & & molasses \\
8 & Johannesburg & not available & ethanol & soya \\
9 & Cape Town & $<151$ million & biodiesel & sugarcane \\
10 & Durban & $<151$ million & ethanol & cellulose \\
11 & Coega & $287-378$ million & ethanol & \\
12 & DURBAN & $<151$ million & $<151$ million &
\end{tabular}


Thailand

\begin{tabular}{|c|c|c|c|c|c|}
\hline Plant No. & City & $\begin{array}{l}\text { Capacity } \\
\text { (litres per year) }\end{array}$ & $\begin{array}{l}\text { Plant location state } \\
\text { (Figure i) }\end{array}$ & Type of biofuel & Feedstock \\
\hline 1 & Thailand & $<151$ million & & biodiesel & palm oil \\
\hline 2 & NakornRatchasima & $<151$ million & & ethanol & sugarcane, molasses \\
\hline 3 & Thailand & $<151$ million & & biodiesel & vegetable oil \\
\hline 4 & Bangkok & $<151$ million & & biodiesel & palm oil \\
\hline 5 & Thailand & $<151$ million & & biodiesel & palm oil \\
\hline 6 & NakornRatchasima & $<151$ million & & ethanol & cassava \\
\hline 7 & Burirum & $<151$ million & & ethanol & sugarcane, molasses \\
\hline 8 & Petchaboon & $<151$ million & & ethanol & sugarcane, molasses \\
\hline 9 & UdornThanee & $<151$ million & & ethanol & cassava \\
\hline 10 & Thailand & $<151$ million & & biodiesel & multiple feedstock \\
\hline 11 & Thailand & 151-283 million & & biodiesel & multiple feedstock \\
\hline 12 & Rayong & $<151$ million & & ethanol & cassava \\
\hline 13 & & $<151$ million & & ethanol & \\
\hline 14 & Khon Kaen & $<151$ million & & ethanol & molasses \\
\hline 15 & Ratchaburi & $<151$ million & & ethanol & sugarcane, molasses \\
\hline 16 & Kanchanaburi & $<151$ million & & ethanol & sugarcane, molasses \\
\hline 17 & NakornRatchasima & $<151$ million & & ethanol & sugarcane, molasses \\
\hline 18 & SaKeaw & $<151$ million & & ethanol & sugarcane, molasses \\
\hline 19 & Thailand & $<151$ million & & biodiesel & palm oil \\
\hline 20 & ChaiyaPhoom & $<151$ million & & ethanol & cassava \\
\hline 21 & Ayutthaya & $<151$ million & & ethanol & molasses \\
\hline 22 & Bangkok & $<151$ million & & ethanol & \\
\hline 23 & NakornRatchasima & $<151$ million & & ethanol & sugarcane, molasses \\
\hline 24 & Bangkok & $<151$ million & & ethanol & \\
\hline 25 & KhonKhen & $<151$ million & & ethanol & sugarcane, molasses \\
\hline 26 & Suphanburi & $<151$ million & & ethanol & molasses \\
\hline 27 & PaJeenburi & $<151$ million & & ethanol & cassava \\
\hline 28 & Ratchaburi & $<151$ million & & ethanol & sugarcane, molasses \\
\hline 29 & Thailand & $<151$ million & & biodiesel & palm oil \\
\hline 30 & Thailand & $<151$ million & & biodiesel & palm oil \\
\hline 31 & Suphan Buri & $<151$ million & & ethanol & \\
\hline 32 & Nakhon Pathom & $<151$ million & & ethanol & \\
\hline 33 & NhongBuaLampoo & $<151$ million & & ethanol & sugarcane, molasses \\
\hline 34 & Khon Kaen & $<151$ million & & ethanol & \\
\hline 35 & Mae Sot & 287-378 million & & ethanol & sugarcane \\
\hline 36 & & 151-283 million & & ethanol & \\
\hline 37 & & 287-378 million & & ethanol & cassava \\
\hline 38 & Thailand & $<151$ million & & biodiesel & palm oil \\
\hline 39 & Saraburi & $<151$ million & & ethanol & molasses \\
\hline 40 & ChaiyaPhoom & $<151$ million & & ethanol & molasses \\
\hline 41 & KhonKhen & $<151$ million & & ethanol & cassava \\
\hline 42 & Bangkok & $<151$ million & & ethanol & \\
\hline 43 & Bangkok & $<151$ million & & ethanol & cassava \\
\hline 44 & Thailand & $<151$ million & & biodiesel & palm oil \\
\hline
\end{tabular}




\section{Venezuela}

\begin{tabular}{clllll}
\hline Plant No. & City & $\begin{array}{l}\text { Capacity } \\
\text { (litres per year) }\end{array}$ & $\begin{array}{l}\text { Plant location } \\
\text { state (Figure i) }\end{array}$ & Type of biofuel & Feedstock \\
\hline 1 & Tinaquillo, Estado Cojedes & $<151$ million & biodiesel & multiple feedstock \\
\hline
\end{tabular}

\section{Zambia}

\begin{tabular}{cllll}
\hline Plant No. City & $\begin{array}{l}\text { Capacity } \\
\text { (litres per year) }\end{array}$ & $\begin{array}{l}\text { Plant location } \\
\text { state (Figure i) }\end{array}$ & Type of biofuel & Feedstock \\
\hline 1 & $<151$ million & biodiesel & jatropha \\
2 & $<151$ million & biodiesel & jatropha \\
3 & $<151$ million & biodiesel & jatropha \\
4 & $<151$ million & ethanol & sugarcane \\
\hline
\end{tabular}




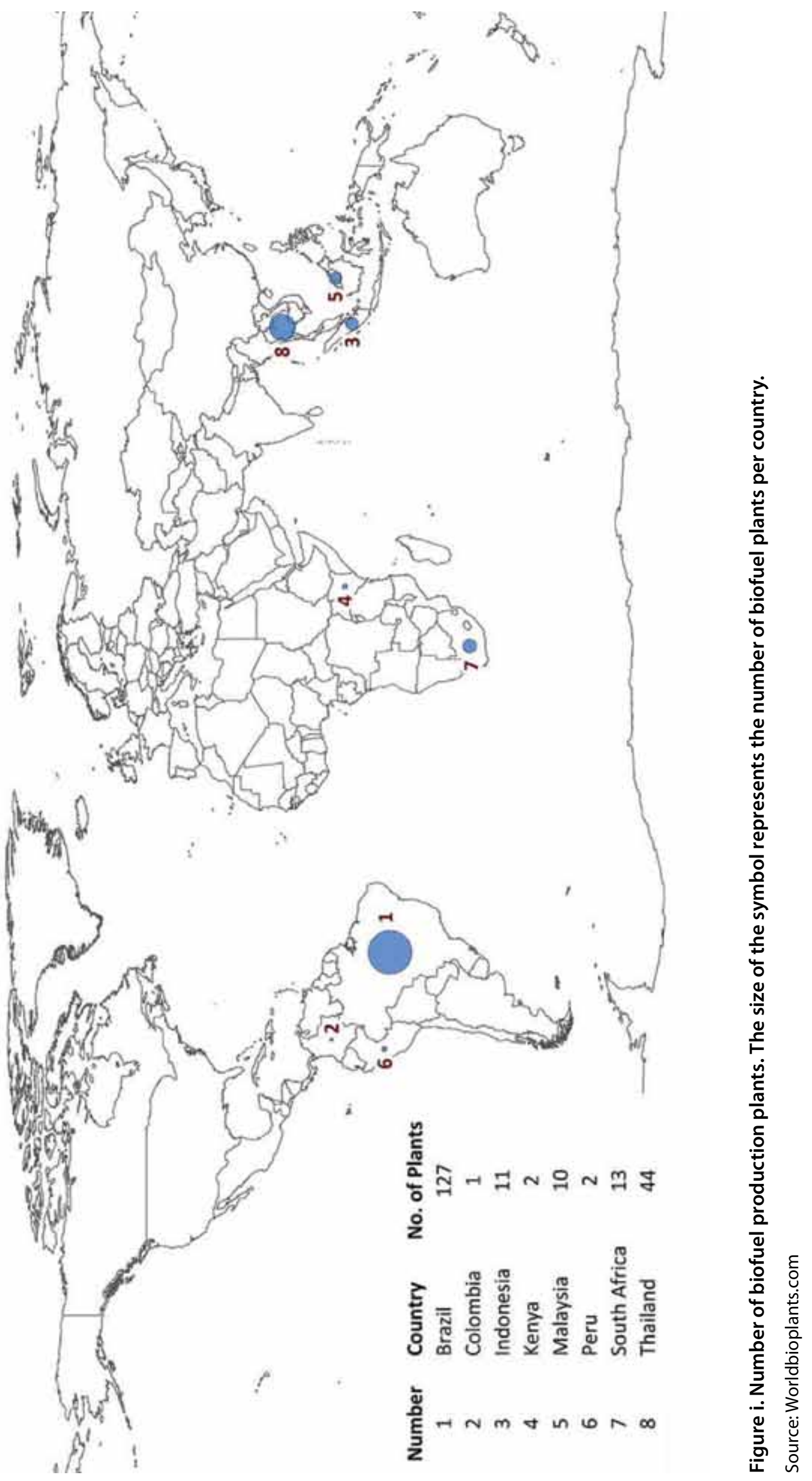




\section{Appendix 3}

\section{Additional information on selected biofuel feedstocks}

\section{Jatropha}

A key attribute of jatropha used to promote its applicability as a biofuel crop is the perception that it is a dryland crop that can grow well on marginal land and in areas of low rainfall. Although the species is clearly drought hardy, useful yields from arid regions seem unlikely. Although data is still sketchy on yields, it is likely that at least $600-800 \mathrm{~mm}$ of rainfall will be required before meaningful crops can be obtained (Achten et al. 2010). Initial published yields from jatropha are often less than envisaged in many projects. Jongschaap et al. (2007) attributes this to the data coming from young plantations and they are optimistic that high yields will still be achieved. Other researchers are less optimistic (Achten et al. 2008). Jatropha growth rates and yields respond positively to fertilisation and pruning, weed control (Everson personal communication 2008), water and soil quality, and it is becoming clear that extensive management is required if high yields are to be achieved. This contradicts early assumptions that jatropha was a low input species.

\section{Impact on agriculture development}

GEXSI 2008a, 2008b, 2008c suggests that the introduction of jatropha plantations should have limited or no impacts on food security, as almost none of the land planted is agricultural (Table 1).

However, verification of these findings through actual case studies is needed, especially where small-scale farmers are concerned. It is becoming more apparent that although jatropha can grow on marginal sites, it is only in good sites that high yields are achieved. If jatropha proves to be profitable, then there is a risk that future plantations will move to better sites where they will compete more directly with food production.

\section{Oil palm}

Oil palm is native to west African humid tropics, the Congo basin and central Africa, growing wild in secondary forest. The oil palm belt starting from Guinea, at $10-11^{\circ} \mathrm{N}$, runs through Sierra Leone, Liberia, Côte d'Ivoire, Ghana, Togo, Benin, Nigeria, Cameroon, the Peoples' Republic of Congo and the Democratic Republic of Congo (DRC) (Hartley 1988).

Although 21 African countries grow oil palm, the continent's world market share is negligible. Nigeria is the largest producer with a market share of $3 \%$; Côte d'Ivoire and DRC follow, both with a market share of around $0.5 \%$. Traditionally, oil palm is used for cooking in these regions. The market is mainly regional. The oil palm sector regained attention these last few years with the development of biofuel and attracts lot of investment from external companies. The increasing biofuel market is an opportunity for oil palm development but it raises also concerns with negative social, economic and ecologic impacts.

Table 1. Former land use of jatropha plantations

\begin{tabular}{lccccc}
\hline & Wasteland & Agriculture land (non- food) & Forest sector & Agriculture land (food) & Primary forest \\
\hline Asia & $54 \%$ & $42 \%$ & $4 \%$ & $0 \%$ & $0.4 \%$ \\
Latin America & $51 \%$ & $30 \%$ & $13 \%$ & $6 \%$ & $0 \%$ \\
Africa & $30 \%$ & $58 \%$ & $7 \%$ & $5 \%$ & $0 \%$ \\
\hline
\end{tabular}

Source: GEXSI (2008a, 2008b, 2008c) 


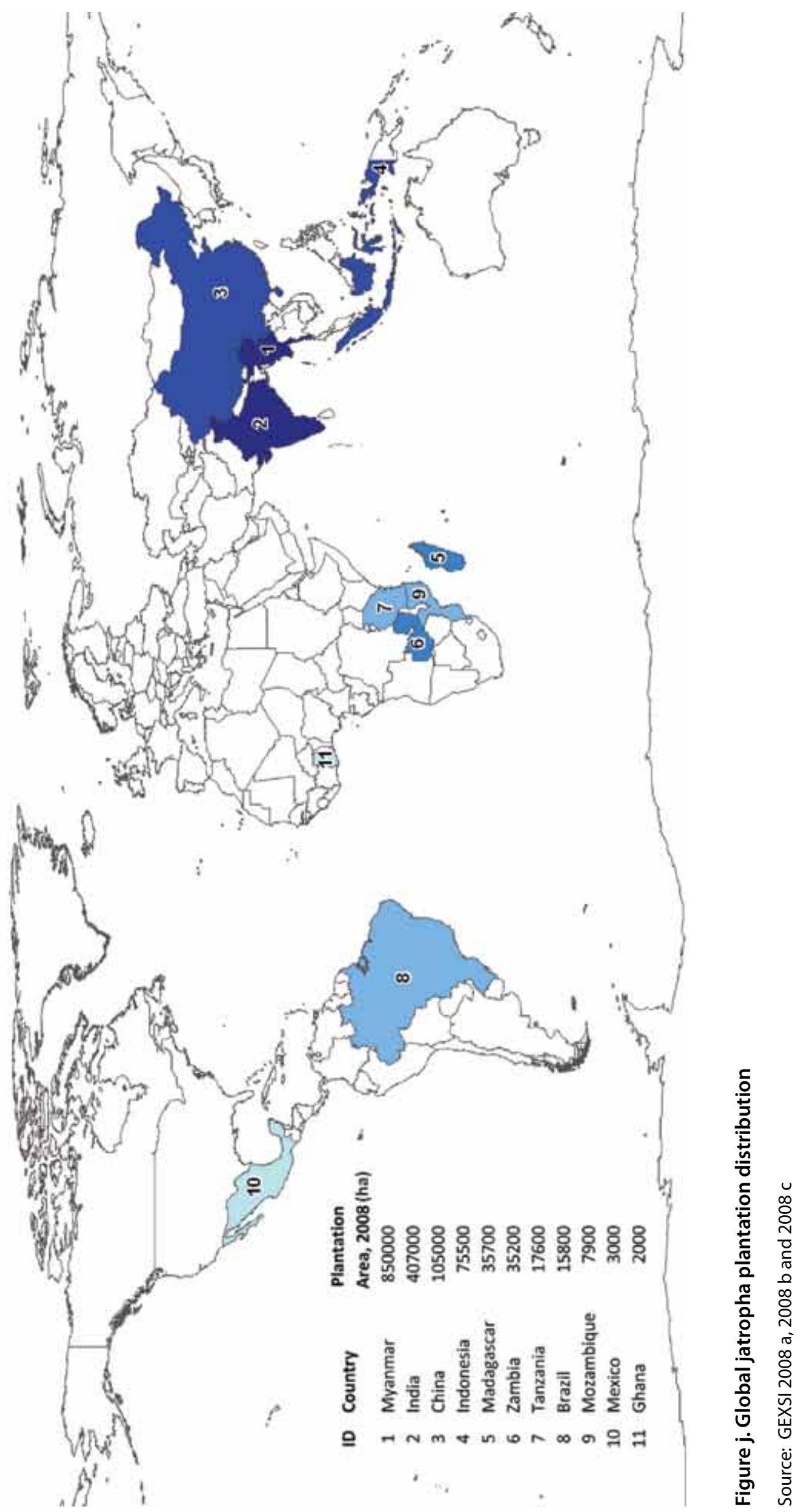




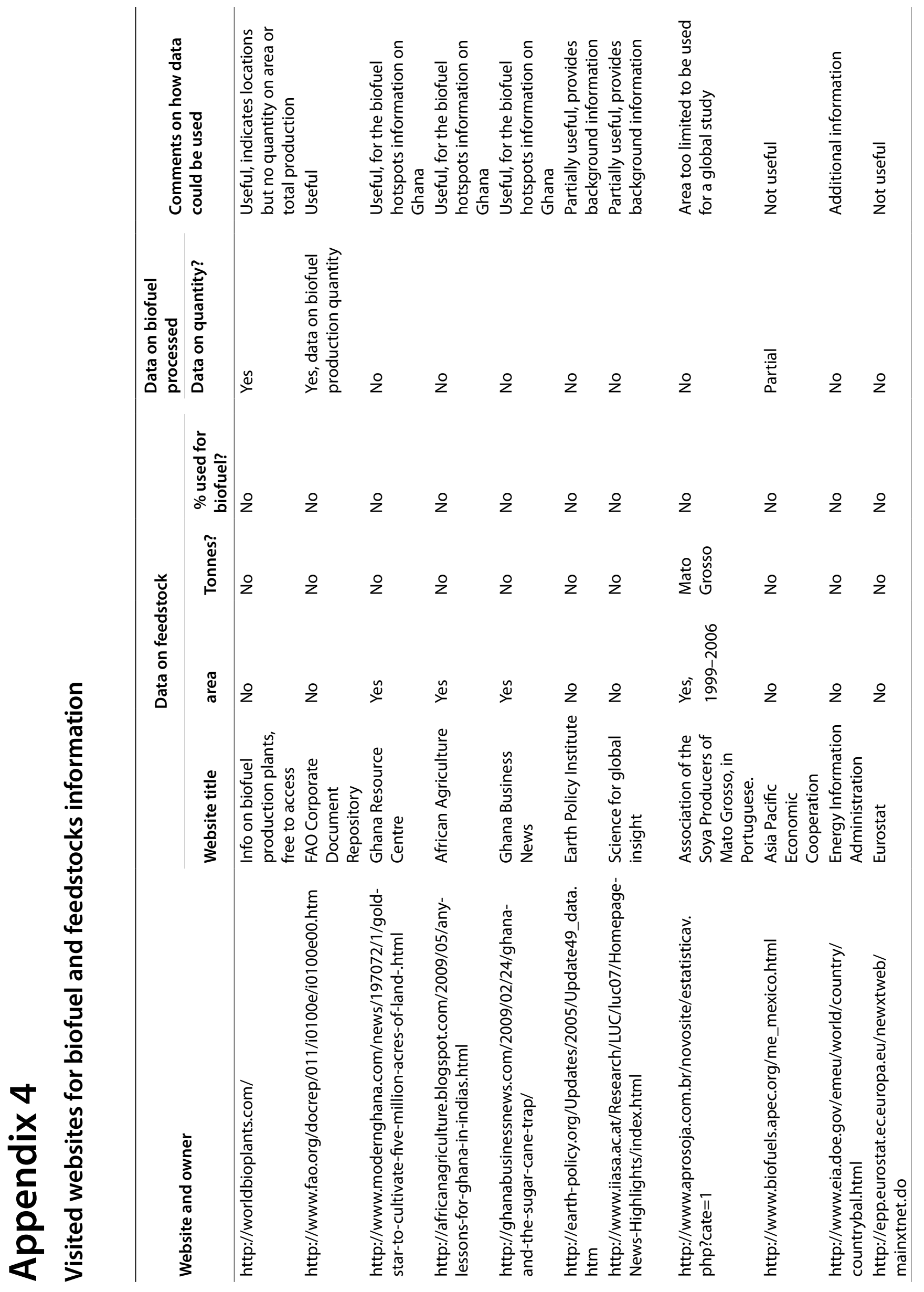




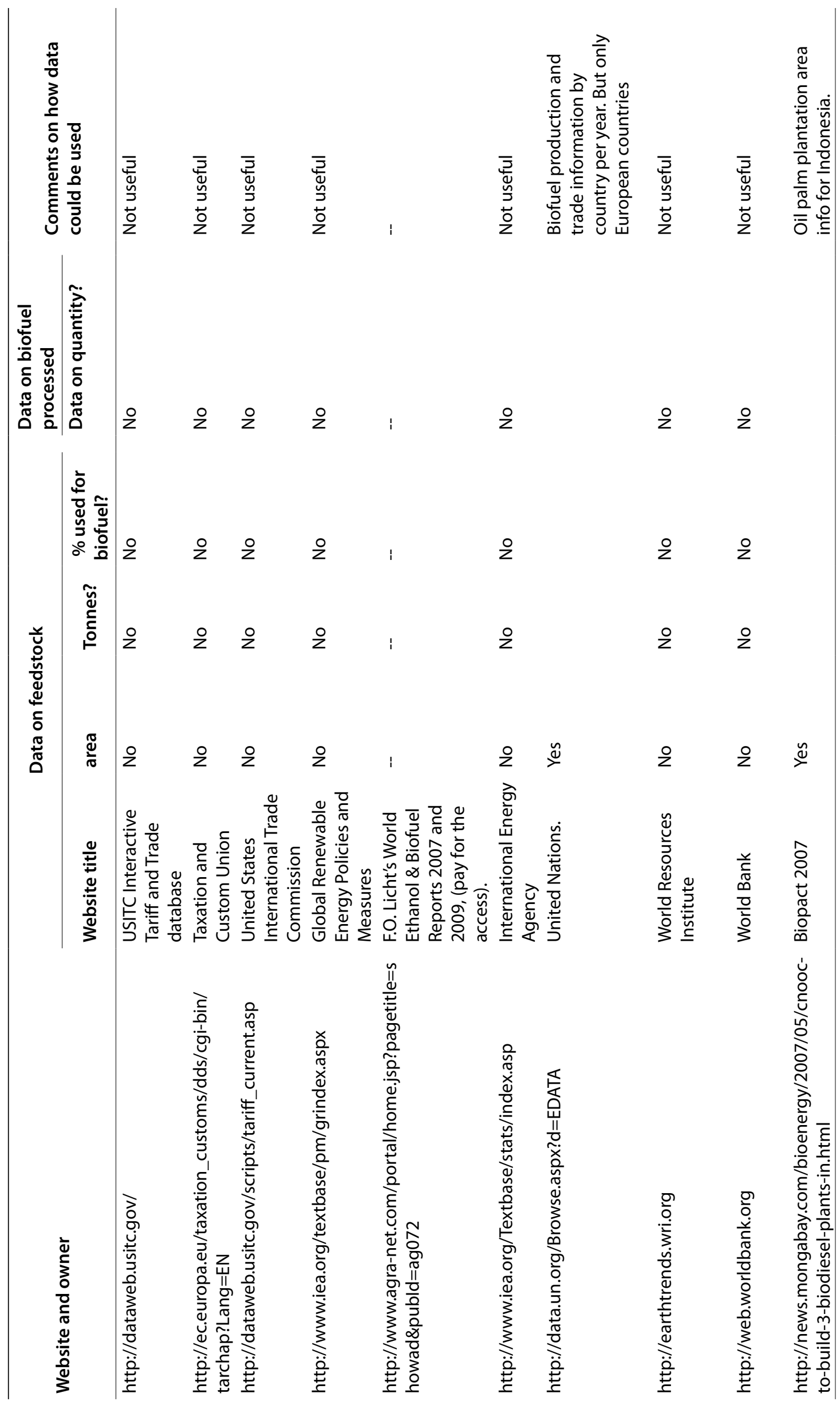




\section{Appendix 5}

\section{Selected hotspots on biofuel development and deforestation in tropical countries}

This section includes 11 selected hotspots for biofuel development in Latin America, SE Asia and subSaharan Africa, seeking to provide more in-depth understanding of the relationships between feedstock expansion for biofuel production and deforestation.

Two hotspots are related to the expansion of sugarcane and thus bioethanol production: one in São Paolo in Brazil and another in Valle del Cauca in Colombia. The remaining nine cases relate to biodiesel production. Specifically, three cases address oil palm in Kalimantan (Indonesia), Malaysia and Colombia, respectively. One case analyses the expansion of soybean in Mato Grosso, Brazil. Finally, three cases in sub-Saharan Africa (Ghana, Tanzania and Mozambique), one in Brazil and one in India illustrate the expansion of biodiesel from jatropha. The analysis of each hotspot is organised as follows: a short introduction, the characteristics of feedstock production, main drivers and expansion plans, companies involved in the production and main business model, and finally an assessment of the socioeconomic and environmental impacts of biofuel production when available.

\subsection{Sugarcane for bioethanol production in São Paolo, Brazil}

\section{Introduction}

Brazil is the most important producer of bioethanol based on sugarcane. Sugarcane has been an important crop since the initial colonisation period, although it is nowadays expanding its cultivated area considerably, particularly due to strong ethanol demand. This in part resulted from an active public policy set up to promote the bioethanol industry's development since the mid-1970s, and an important response from the private sector. Nonetheless, the bioethanol industry did not consolidate until the early 2000s when an increase in oil prices and growing internal demand for bioethanol, fostered by the adoption of flex-fuel cars in the national market, led to a significant expansion of sugarcane and bioethanol production.
Almost all the sugarcane in Brazil is produced in the south-central and northeast regions, $83 \%$ and $17 \%$ respectively. São Paolo is the most important state for sugarcane, representing $55.7 \%$ of the total sugarcane area in Brazil in 2008 (Meloni et al. 2008). The expansion of bioethanol production has motivated an intense debate about the local and national social, economic and environmental implications. While on the one side, some argue that bioethanol production constitutes a cleaner source of energy, contributes to economic development and has little effect on indirect deforestation (Goldemberg et al. 2008), on the other side, critics suggests that bioethanol production induces greater forest conversion and increases the pressure on land for food production (BWC 2009).

\section{Production dynamics}

Brazil has traditionally been a sugarcane producer, and its cultivated areas and yields are among the highest in the region. According to the Brazilian Institute of Geography and Statistics (IBGE) (2009), the cultivated area with sugarcane has increased from 4.8 million ha in 1996 to 7.1 million ha in 2006, while the Brazilian Sugarcane Industry Association (UNICA) (2009) reported that sugarcane production grew from 222 to 425 million tons in the same period, and rose to 569 million tons in 2009. Most production is located in the south-central region (4.6 million ha, 504 million tons in 2009), and it is expanding gradually (Figures $a$ and $b$ ). Less land is cultivated with sugarcane in the states of Pernambuco and Alagoas in the northeast region, although the area is growing slowly.

Table a contains the main indicators for the sugarcane and ethanol sector in Brazil. In 2007-08 sugar production reached 30 million tons, and ethanol production was equivalent to 22 billion litres, increasing to 25 billions litres in 2009. Ethanol production is growing rapidly from only 12 million tones in 1990 (F.O. Litch 2009). Most sugar produced in Brazil targets the foreign market (64\%), while only a third (36\%) supplies domestic demand. 

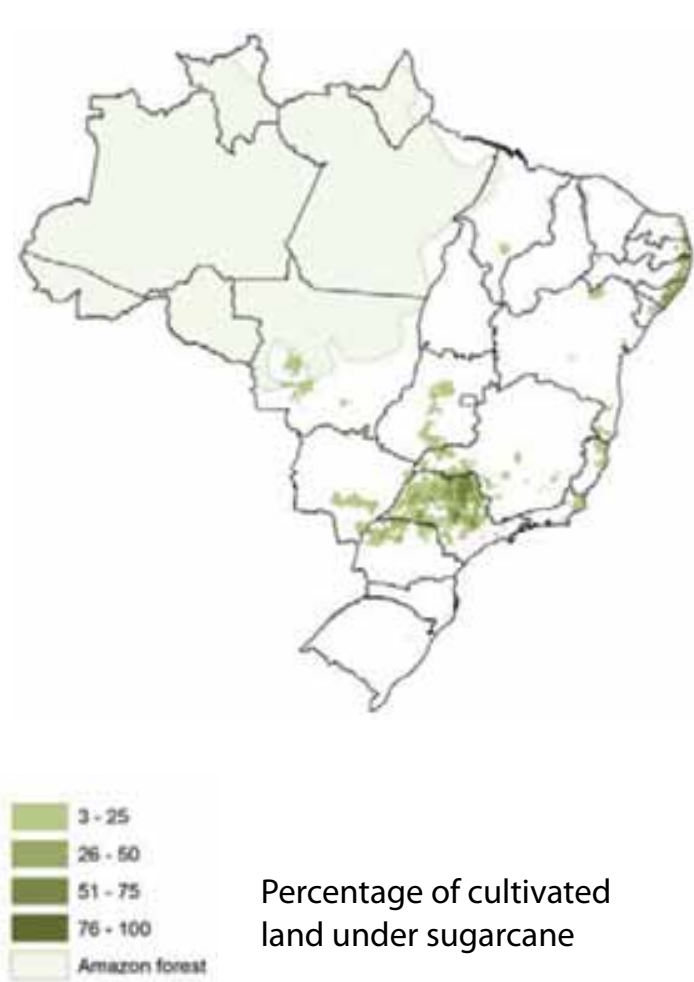

Percentage of cultivated land under sugarcane

Figure a. Location of sugarcane plantations

Source: Adapted from IBGE (2009)

Table a. Sugarcane and bioethanol production and distribution in Brazil

\begin{tabular}{llcc}
\hline \multirow{2}{*}{$\begin{array}{llc}\text { Production } \\
(2007 / 08)\end{array}$} & Sugarcane & \multicolumn{2}{c}{490 million tons } \\
& Ethanol & \multicolumn{2}{c}{22 billion litres } \\
& Sugar & Domestic & Foreign \\
& & market & market \\
\multirow{2}{*}{ Distribution } & Sugar & $36 \%$ & $64 \%$ \\
& Ethanol & $85 \%$ & $15 \%$ \\
\hline \multirow{2}{*}{ No. of } & Total & Sugar and & Ethanol \\
plants & & ethanol & \\
& 350 & 250 & 100 \\
\hline
\end{tabular}

Source: Sawaya and Nappo (2009)

In contrast, $85 \%$ of ethanol production covers the internal market, and the rest is exported $(33 \%$ to the US, about 38\% to the European markets) (Table a), where demand of ethanol is growing to accomplish their blending targets. As of 2008, about 250 refineries were dedicated to producing sugar and ethanol, and approximately 100 refineries exclusively for ethanol production.

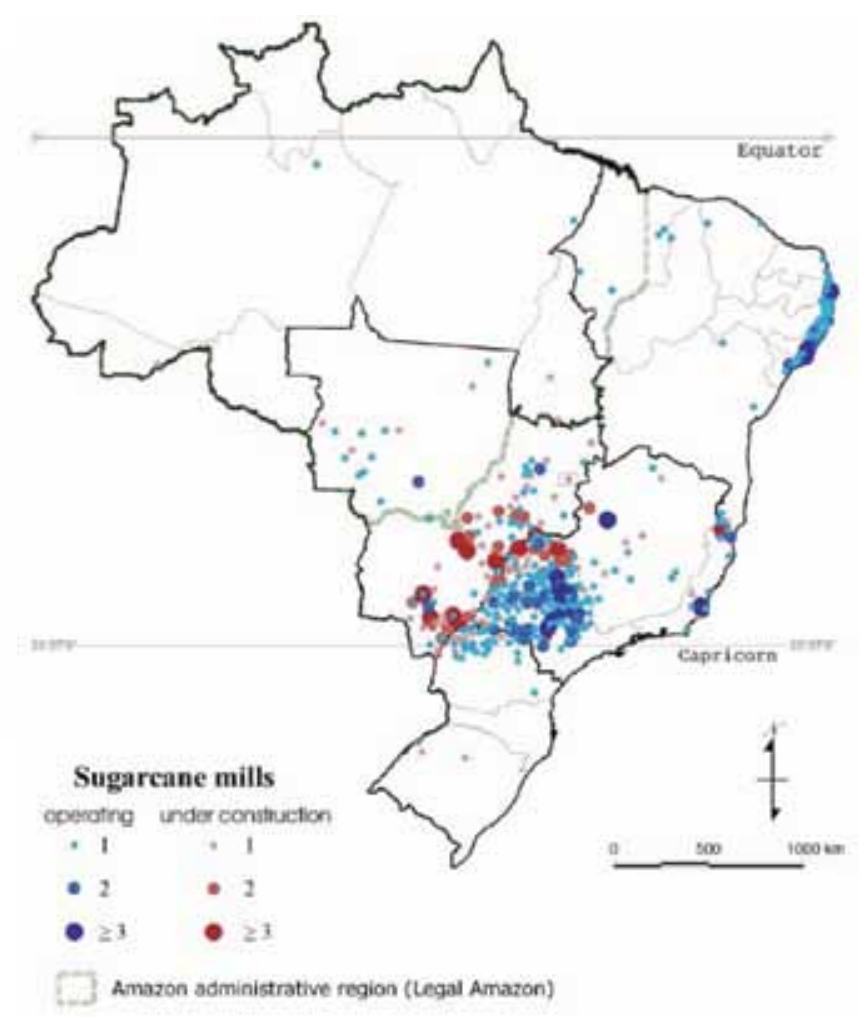

Figure b. Sugarcane mills distribution in Brazil

Source: Sparovek and Berndes (2008)

The main driver expanding the Brazilian biofuel sector is the Ethanol Program (PROALCOOL), which started in 1975 (Decree 76.593/75), in a context of growing oil prices, with the goal of reducing the national dependency on imported oils. This program also aimed to support the sugar industry by creating an alternative domestic market for ethanol. From 1975 to 1980 , in the first phase of the PROALCOOL program, ethanol production was increased by building new distilleries annexed to existing sugar mills. In 1980, a production goal of 10.7 billion litres per year of hydrated ethanol was established. Main incentive policies for bioethanol production included differentiated price levels for both ethanol and gasoline, suppression of taxes for alcohol production, and concessionary credit lines for industrialists to build autonomous ethanol distilleries (Rutz et al. 2009).

In 1984, a new phase started with an ethanol production target of 14.3 billion litres per year. In 1986 the Federal Government reviewed the incentive policies, which reduced the profitability 
of ethanol production. This led to an increase in sugar production aiming at the international market. Lower international prices of oil and thus low gasoline prices in the domestic market influenced on the decline in sales of ethanol vehicles: $88 \%$ in $1988,61 \%$ in $1989,20 \%$ in 1990 , and only $0.3 \%$ in 1996. The latter translated into lower sales of E100 (hydrated ethanol). Also, supply shortages occurred in certain zones of the country, as PROALCOOL production goals were not achieved (Rutz et al. 2009). In 1991, the Federal Government started a progressive removal of subsidies that concluded in 1999. In 2003, flex-fuel cars were launched in the Brazilian market in a context of rising gasoline prices. By 2008, 89\% of all new cars sold were flex-fuel types. This removal of subsidies constituted a strong incentive that prompted bioethanol production (Rutz et al. 2009).

\section{Companies involved and business models}

In Brazil, the sugar industry has undergone an important process of modernisation in recent years. Many sugar industrial plants emerged vertically integrated from the sugarcane growers. However, the sector is relatively fragmented with about 250 plants dedicated to sugar and ethanol production, and 100 ethanol refineries (Table a). According to Neves et al. (2009), on average, $65 \%$ of the cultivated land would be owned or leased by mills, and 35\% belongs to independent producers (around $70000 \mathrm{ha}$ ) under some form of supply contract. However, the industry has recently trended towards greater concentration since some large transnational groups entered the sector, and greater foreign direct investment has stimulated some merging of mills. Currently, the 15 largest producers account for $35 \%$ of the total sugarcane crushed in the country (Neves et al. 2009).

Only two transnational companies are in the Brazilian sugarcane sector, both of which are French groups. The first is Tereos (Açúcar Guarani) and the second is Louis Dreyfus Commodities (LDC). Nonetheless, many sugarcane and bioethanol companies have benefited from foreign investment that has merged with national capital. By the middle of 2007, the UNICA projected that volume of sugarcane processed by foreign companies would reach $10 \%$ of the total production. It is likely to assume that foreign investment will continue growing in the future. Yet, foreign capital is not interested in land assets but in producing sugarcane and ethanol, and companies choose leasing or supply contracts to increase their supply of raw material. However, over time, some more capitalised companies, mainly large-scale international corporations, might get more interested in expanding their assets, including land, and in acquiring existing mills (Neves et al., 2009).

\section{Socioeconomic impacts}

Sugarcane is one of the leading crops in the agribusiness sector, and the sugarcane sector (including ethanol production) contributes significantly to the national GDP. It constitutes an important source of jobs since it employs, directly and indirectly, about 4 million people (Neves et al. 2009). However, the sugarcane industry is often heavily criticised due to the precarious labour conditions, particularly for sugarcane harvesting (BWC 2009). The industry response is a gradual transition from manual to mechanised harvesting, which results in fewer jobs. In addition, biofuel production has contributed significantly to supplying an alternative energy source for transportation, whose contribution increases in times of high oil prices (Goldemberg et al. 2008). In addition, the sector is growing in importance due to the cogeneration of energy originated in bagasse. This energy is not only used for the mills' operation but also can be sold to the electricity network. According to UNICA (quoted in Neves et al. 2009), sugar and ethanol units had, in 2008, generated 1800 megawatts of surplus energy, which represents around 3\% of Brazilian energy needs.

\section{Environmental impacts}

Meloni et al. (2008) evaluates the direct land use change effects from sugarcane development in the state of São Paolo, using satellite images from different dates; it suggests that from 2005 to 2008, sugarcane cultivation expanded by 1.8 million ha. Pasture (53\%; $960000 \mathrm{ha})$ and agricultural land (44.6\%; $808000 \mathrm{ha}$ ) accounted for $97.7 \%$ of the change (1.77 million ha). A further $0.31 \%$ (5500 ha) occurred over forest and reforested lands. By comparison, in Mato Grosso, sugarcane expansion over forestlands accounted for $7.4 \%$ (1892 ha) of total expansion in 2007 and $7.8 \%$ (2385 ha) in 2008. These authors argue that sugarcane expansion takes place in croplands and that deforestation in 
Brazil is observed in agricultural frontiers into which sugarcane has not expanded. Also it has been stated that most of the expansion over pastures is being compensated by more intensive livestock production systems. Further, the Brazilian Government has banned sugarcane production in the Amazon biome.

\subsection{Sugarcane for bioethanol production in Valle del Cauca, Colombia}

\section{Introduction}

Colombia's sugar industry is located in the Valle del Cauca in the country's centre-west. This valley has almost entirely been devoted to sugarcane production for several decades, including raw and refined sugar (Figure c). The industry has supplied the domestic market with sugarcane and exported the surplus. In recent years the Government has stimulated bioethanol production by approving a $10 \%$ ethanol blend by 2006 and a $25 \%$ blend within 15 years, supported by tax holidays and subsidised credit. As result, Colombian sugar production has fallen since
2004 and ethanol production has steadily increased since 2005 . The production dynamics do not affect the sugar supply to fulfil the domestic demand, but tend to influence the sugar export volumes (Toasa 2009). The ethanol price is regulated by the Government, which protects the industry at the expense of the final consumers.

Most of Colombia's sugarcane plantations and ethanol plants are in the Valle del Cauca because its rich soils and weather conditions allow for relatively high yields. The total crop area is about 210000 ha, and sugarcane production was around 2.53 million tons per year in 2009, recovering from a slight decline in the two previous years (ASOCAÑA 2010). Production levels have oscillated slightly between the 18 and 23 million tons per year in the decade since 2000 (Table 1). It is noteworthy that not enough land is available in the Valle del Cauca to expand sugar cultivation, although the sector has improved productivity, making Colombia among the most productive sugarcane countries in the world (Toasa 2009).

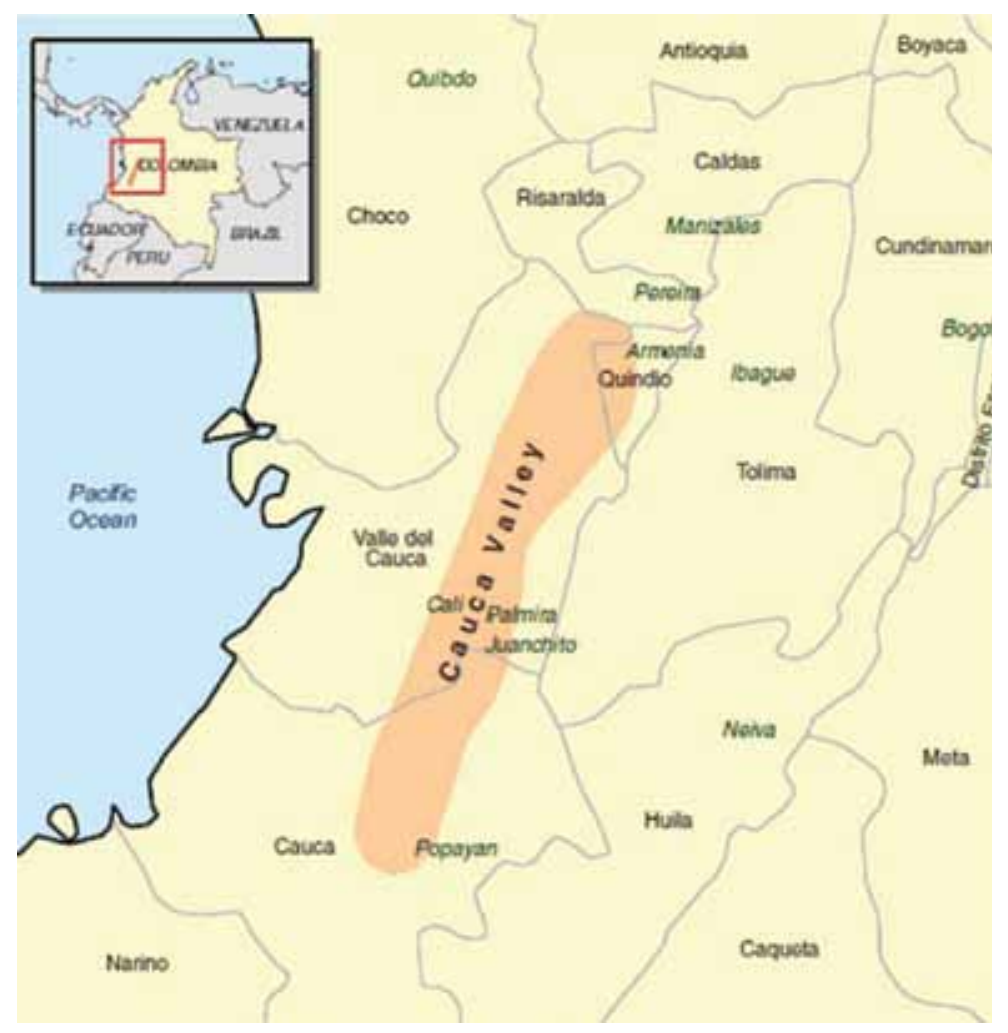

Figure c. Location of sugarcane production zones in the Valle de Cauca, Colombia

Source: Toasa (2009) 
Table b. Statistics of the sugarcane sector in Colombia

\begin{tabular}{|c|c|c|c|c|c|c|c|}
\hline & \multirow{2}{*}{$\begin{array}{c}\text { Production sugarcane } \\
\text { (1000 tons) }\end{array}$} & \multicolumn{4}{|c|}{ Refined sugar (1000 tons) } & \multirow{2}{*}{$\begin{array}{l}\text { Alcohol } \\
\text { (1000 lts) }\end{array}$} & \multirow{2}{*}{$\begin{array}{c}\text { Molasses } \\
\text { (1000 tons) }\end{array}$} \\
\hline & & Total & Domestic & Imports & Exports & & \\
\hline 2000 & 19922 & 2391 & 1349 & 17 & 1045 & 0 & 489 \\
\hline 2001 & 18120 & 2245 & 1312 & 58 & 931 & 0 & 480 \\
\hline 2002 & 20505 & 2529 & 1362 & 86 & 1127 & 0 & 572 \\
\hline 2003 & 21669 & 2650 & 1352 & 117 & 1287 & 0 & 595 \\
\hline 2004 & 22165 & 2741 & 1523 & 38 & 1233 & 0 & 618 \\
\hline 2005 & 21785 & 2683 & 1515 & 60 & 1180 & 28953 & 581 \\
\hline 2006 & 22020 & 2415 & 1460 & 126 & 926 & 268544 & 270 \\
\hline 2007 & 21090 & 2277 & 1558 & 161 & 716 & 274832 & 250 \\
\hline 2008 & 19208 & 2036 & 1550 & 165 & 478 & 259748 & 227 \\
\hline 2009 & 23589 & 2598 & 1513 & 138 & 1054 & 327181 & 279 \\
\hline
\end{tabular}

Source: ASOCAÑA (2010)

\section{Production dynamics}

Of the Valle del Cauca 's 400000 ha, about 210000 ha are used for commercial sugarcane production. Bioethanol production yields are relatively high in this region, estimated at around 9000 litres per ha per year (DNP 2008). Total bioethanol production in Colombia was about 327 million litres in 2009 (Table b), produced by five sugar-ethanol mills established in the Valle del Cauca with a processing capacity of 1.05 million litres per day (Toasa 2009).

The Ministry of Agriculture and Rural Development estimates that the country could have between 0.9 and 1.2 million ha that could be used for sugarcane production. Furthermore, the biofuel program has established a goal of 1 million ha planted with feedstock for ethanol production by 2020 (DNP 2008). Since little land is available in the Valle del Cauca region, the industry is looking for land in other areas. Colombia's central and northern parts have been identified as potential sugarcane production areas. The northern departments of Sucre, Bolívar and Córdoba have about 200000 ha that could be devoted to sugarcane production, land that is currently under low productive cattle ranching (Toasa 2009). This area is roughly equivalent to the area cultivated in the Valle del Cauca. It is expected that the new lands will be dedicated to ethanol production.

\section{Socioeconomic impacts}

The sugar industry provided about 36000 direct and 216000 indirect jobs in 2008, which implies that about one million people's livelihoods depend on the sugar industry (Toasa 2009). Information about the quality of these jobs is contradictory. While some argue that labour conditions are precarious and workers do not enjoy security and health services (Pérez and Alvarez 2009), the private sector indicates that significant resources are invested to ensure social security for workers employed in the sugarcane industry (Londoño 2007).

It is also argued that the taxes paid by the sugar mills and ethanol plants constitute a key source of revenue for most municipalities in the Valle del Cauca (Toasa 2009). In contrast, the sugarcane industry favours a process of land concentration, and most rural landholders rent their lands to the sugar companies, which the companies operate in addition to their own plantations. While this business model distributes benefits to private landholders, some argue that most of the income generated by the sector tends to be retained by the industry (Pérez and Alvarez 2009).

\section{Environmental impacts}

The sugarcane industry in the Valle del Cauca was established in the 1950s. All the primary vegetation was replaced by sugarcane plantations, with the monoculture resulting in a drastic reduction in biodiversity and impacts on water availability (Perez and Alvarez 2009). Lately, the sugarcane industry has taken some steps to protect the environment. For example, from 2004 to 2007, the industry spent US\$127.3 million in the Valle del Cauca on activities such as conserving riverbank walls, reforestation and monitoring air quality (Toasa 2009). The same 


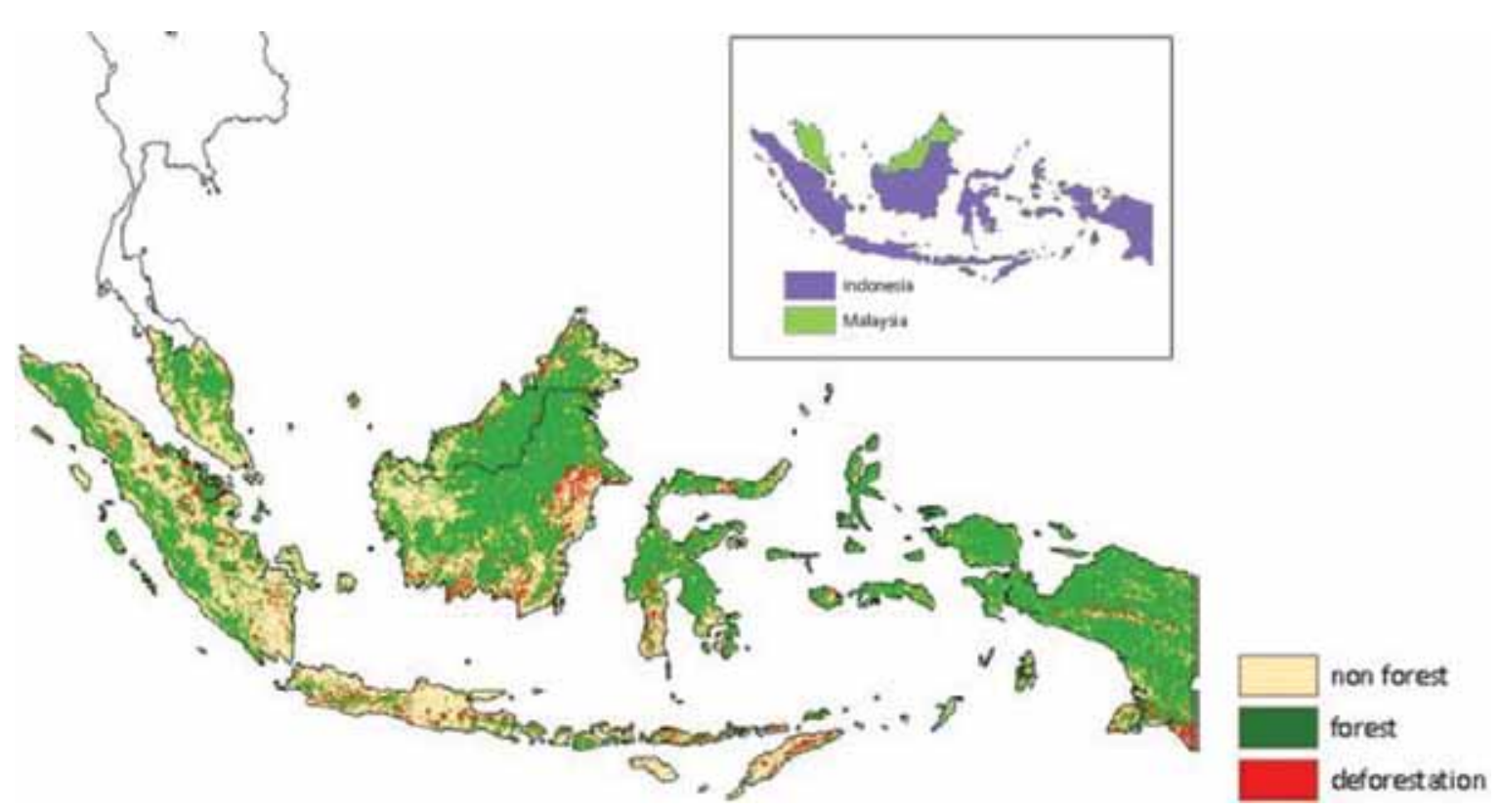

Figure d. Indonesia and Malaysia deforestation hotspots 1999-2006 indicated

Source: SPOT vegetation (WWF-SAR Vision) 1999-2006, $1 \mathrm{~km}$ spatial resolution

author mentions that although the sugar industry is the largest industry in the Valle del Cauca, it accounts for only $2 \%$ of pollution in the Cauca River (Toasa 2009). The increasing conversion of sugar into ethanol is not driving deforestation in current production zones, but some deforestation might take place due to sugarcane plantations expanding in other regions.

\subsection{Oil palm expansion and biodiesel production in Indonesia ${ }^{22}$}

\section{Introduction}

Oil palm entered Indonesia in 1848 when it was planted in Bogor Botanical Garden. It grew successfully into the parent plants producing the seeds that started the palm oil plantation industry in this country (KEHATI et al. 2006). Oil palm began to be planted commercially in 1911 by private companies and state-owned companies on the east coast of Sumatra Island (KEHATI et al. 2006; Bangun 2006). The oil palm plantations significantly expanded by more than 2 million additional hectares from the late 1960s until 1997. Despite its significant contribution to the country's economy,

22 Compiled by Rubeta Andrani, CIFOR. this expansion has occurred at the expense of humid tropical forests cover (Casson 2000).

Several studies have identified the relation between oil palm plantation development and deforestation (Sheil et al. 2009). These last authors also indicate that oil palm development often increased both the degradation of surrounding forests, and the types of human activities that might lead to both intentional and unintentional forest fires igniting; thus many fires near oil palm developments are likely attributable (directly or indirectly) to the plantation. Although the Indonesian Government has banned using fire to clear land, the practice is still occurring up. During the El Nino period in 1997/98, at least 3.3 million ha of tropical forests were burned, with more than $50 \%$ of the fires started by oil palm plantation owners (Kessler 2005).

In Indonesia, deforestation hotspots were observed in Kalimantan, Papua and Sumatra, primarily linked to the expansion of oil palm plantations (Figure d). We describe here the case of Kalimantan (Figure e), which is more closely related to biofuel development.

\section{Kalimantan}

Deforestation in Kalimantan has been related to various activities. In east and south Kalimantan 
most deforestation is related to mining activities and forest concessions, rather than oil palm plantations. In central Kalimantan, 1 million ha of peat swamp forest were drained for Suharto's failed millionhectare rice scheme. West Kalimantan is the leader in oil palm plantation area and production in the island. Sanggau district has the largest area planted to oil palm (155000 ha), and has attracted many investors because of its maturity as an oil palm centre. Its road network is also largely adequate to support the area's oil palm development (Persoon and Osseweijer 2008). Most companies that have indicated an intention to contribute to the biodiesel supply in Indonesia are located in west Kalimantan.

\section{Production dynamics}

Oil palm has expanded since the late 1960s (Casson 2000), although biofuel production has been authorised since 2006 by stipulating a mix of renewable fuels to make up $5 \%$ of all energy consumed by 2025 (Presidential Regulation
2006). This has encouraged the use of oil palm for biodiesel production, though it is unknown in what proportion. The Government provides incentives such as tax holidays, interest rate subsidies (Sheil et al. 2009) and a reduction in price subsidies on fossil fuels in 2005, in order to make the biofuel industry economically viable. The Government also encourages the development of crops on land estates, including oil palm plantation through a program called revitalisasi perkebunan (plantation revitalisation), where growers are given soft loans to establish oil palm devoted to biodiesel production.

The Crude Palm Oil (CPO) produced in Indonesia has been used mostly to produce cooking oil and cosmetics, perhaps as much as $70 \%$. There is no definite information on the size of biofuel plantations. In fact, strictly speaking, no oil palm plantations have been developed exclusively for biodiesel production since most supply conventional food markets.

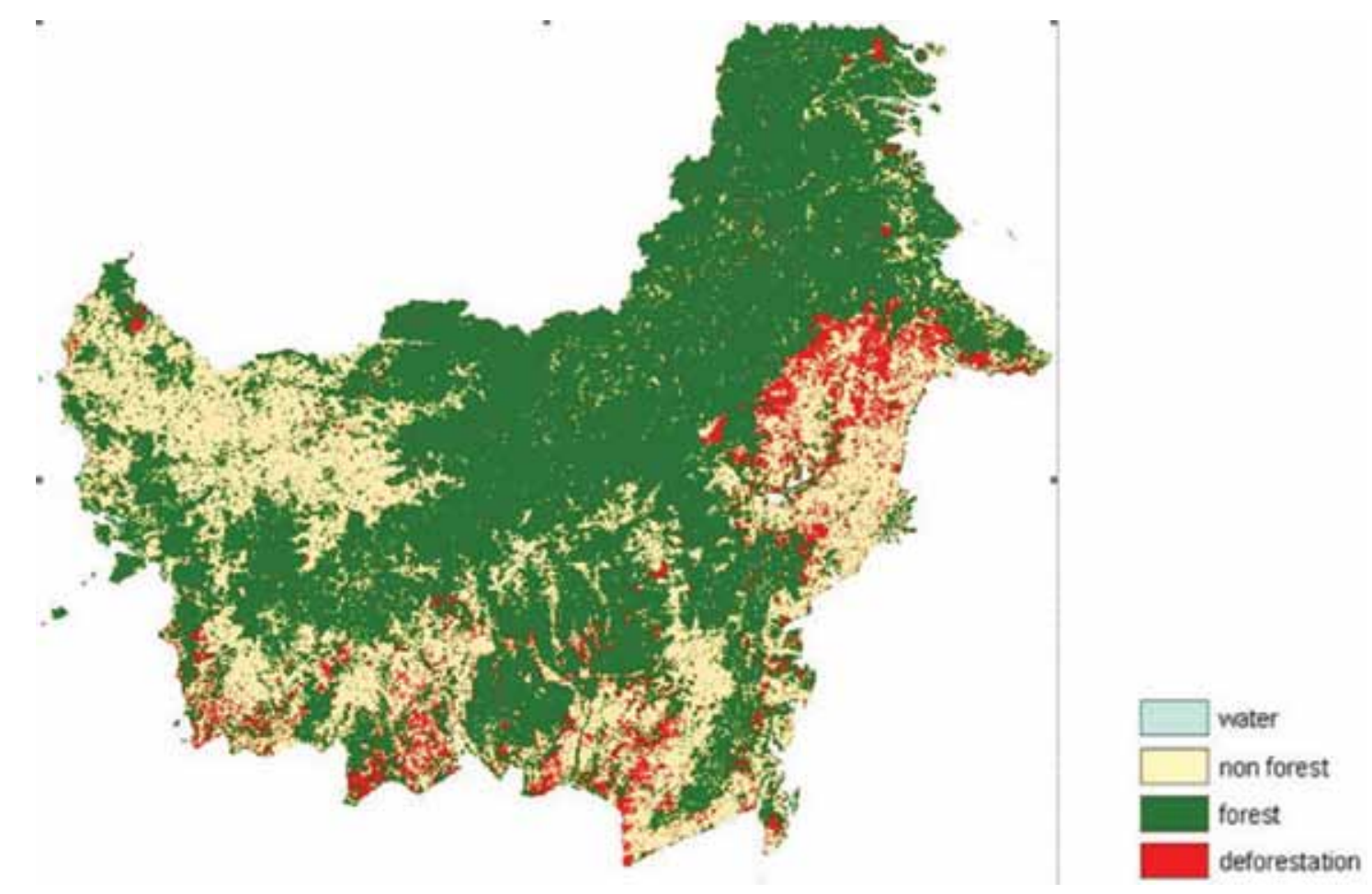

Figure e. Deforestation in Kalimantan 1999-2006

Source: SPOT vegetation (WWF-SAR Vision) 1999-2006, $1 \mathrm{~km}$ spatial resolution 
The development of oil palm plantations in Indonesia has been driven by the sustained increase of CPO prices on the global market. In 2000, the oil palm plantation estate was 4.2 million ha, increasing to about 6.1 million ha and 7.6 million ha in 2006 and 2009 , respectively. The use of CPO for biodiesel has also become a driving force behind the increase in plantation area, in part stimulated by the renewable energy policy issued in 2006, as mentioned earlier. The current installed processing capacity is 3 billion litres per year for biodiesel and 200 million litres per year for bioethanol. Assuming that 1 ha of oil palm produces 5000 tonnes or 6000 litres of CPO, around 500000 ha of oil palm plantation (or $6.5 \%$ of the total planted area) is required to meet the biodiesel industry's need.

The Indonesian Government plans to allocate 6 million ha of land for biofuel development, including 3 million ha for oil palm and 1.5 million ha each for jatropha and cassava (FAO Regional Office for Asia and the Pacific 2008). In addition, an industrial development program was launched to build 11 biofuel plants, with production targets of 187 million litres in 2007 and 1.3 billion litres by 2010 (Ministry of Energy and Mineral Resources Republic Indonesia 2006, Mongabay 2006).

\section{Companies involved and business models}

A large number of oil palm plantations are in the country, but few companies-either growers or biodiesel refinery mills-have already declared that they would produce $\mathrm{CPO}$ for biodiesel or that they would secure CPO supplies from certain oil palm companies. Several large companies plan to establish oil palm for biodiesel production. ${ }^{23}$ Neste Oil, one of the world's largest producers of renewable diesel, operates a plant in Porvoo, Finland, and is establishing another plant in Singapore with the capacity of 800000 tonnes per year. It is likely that these plantations will reproduce similar models in most oil palm plantations, which are dominated by vertical integration and the establishment of outgrower schemes with smallholders.

23 They include Wilmar Group in Sumatra and Borneo (180 000 ha), Genting Group in Merauke, Papua (400 000 ha), Sinar Mas in West Kalimantan and Merauke, Papua (440 000 ha), Tolaram in West Kalimantan (110 000 ha), Muting Group in Merauke, Papua (290 000 ha) (Legowo 2007).

\section{Socioeconomic impacts}

People displacement was observed during oil palm plantation development, for example, in Sanggau District in West Kalimantan (Friends of the Earth et al. 2008). Smallholders who depend on forests practise shifting agriculture and supplement their diet with a wide variety of wild plants and animals; these people often struggle to adapt to the monotonous work in the plantation area. Therefore, large oil palm companies often hire staff from Java, Sumatra or Sulawesi. This may contribute to ethnic conflict (Sheil et al. 2009).

Biofuel development is believed to further increase the rate of oil palm plantation expansion in many regions, which has resulted in land conflicts due to unclear property rights over local people's land and the lack of local consent and participation in decision making on land allocation. Often, conflicts occur due to broken promises by the companies who had committed to building farms and social facilities and providing employment once plantations have been established.

\section{Environmental impacts}

In Indonesia oil palm expansion is still considered to be a major deforestation driver, as obtaining a land clearing permit can be easier than a logging permit, and some investors use oil palm to gain access to timber (Sheil et al. 2009). Therefore, inasmuch as biodiesel contributes to the expansion of the area under oil palm, there will be a direct pressure on existing forests and a link to deforestation. As currently biodiesel represents approximately $6.5 \%$ of the total area planted to oil palm, and most plantations have been established on previously native forests, we can then assume that about $6.5 \%$ deforestation is coming from biodiesel.

\subsection{Oil palm expansion and biodiesel production in Malaysia ${ }^{24}$}

\section{Introduction}

Malaysia is the second largest oil palm producer after Indonesia (Koh and Wilcove 2008). Its oil palm production occupies around 3.7 million ha, of which

24 Compiled by Rubeta Andrani, CIFOR. 
two million are in peninsular Malaysia and the rest in the east Malaysian states of Sabah and Sarawak (Wahid et al. 2004). Due to rising fossil fuel prices, the Malaysian Government, along with other Asian countries, set up plans to produce biodiesel from oil palm. This biofuel policy was developed when palm oil prices were relatively low and the possibility of replacing some petroleum use with biofuel appeared feasible. The policy refers to a $5 \%$ biofuel mandate, using palm oil as the feedstock (Lopez and Laan 2008). However, due to the currently high prices of crude palm oil, only four out of 91 biodiesel producers begun the operation (Nagarajan 2008).

\section{Production dynamics}

Oil palm plantations have been established in Malaysia for biodiesel production under the Government's national biofuels policy. The policy aims to supplement the depleting supply of fossil fuels with renewable resources; mobilise local resources for biofuel production; exploit local technology to generate energy for the transportation and industrial sectors; pave the way for biofuels export; and, benefit from the spin-off effects of more stable prices for palm oil (Lopez and Laan 2008). Malaysia's first commercial biodiesel plant commenced operations in August 2006; it produced 55000 tonnes of biodiesel during that year, increasing to 130000 tonnes in 2007 (Lopez and Laan 2008).

During 2009, biofuel exports increased by $24.9 \%$ to 0.23 million tonnes, up from 0.18 million tonnes recorded in 2008. The EU was the largest biodiesel export market, accounting for 119277 tonnes (or $52.4 \%$ of total biodiesel exports), followed by USA with 39594 tonnes (Wahid 2010). In accordance to this national policy, the State of Sarawak targeted the oil palm development of 1 million ha by 2010, of which 300000 ha are to come from Native Customary Rights (NCR), bringing the total area for cultivation to nearly 2 million ha. In the State of Sabah, total oil palm cultivation in 2008 reached 1.4 million ha, producing 5.8 million tonnes $\mathrm{CPO}$, according to the Palm Oil Industrial Cluster of Malaysia website.

The first commercial oil palm planting took place in 1917 in Selangor and continued to expand on peninsular Malaysia. Planting commenced in Sabah in the late 1970s through the late 1990s, then began expanding to eastern Malaysia and Indonesia, while the experimental biofuels program began in 1982 (Lopez and Laan 2008). Biodiesel production on a commercial scale started in 2006 (Lopez and Laan 2008), reaching approximately 130000 tonnes in 2008 (the equivalent of around 30000 ha of land), from eight biodiesel plants. In recent years, the capacity of oil palm-based biodiesel production in Malaysia has expanded rapidly and government officials are now concerned about overcapacity and the ability of some biodiesel vendors to operate effectively due to the potential shortage of raw material. Concerns over the potential competition with palm oil for food and the volatility of the biofuel market have caused officials to slow the growth of the biofuel sector.

\section{Companies involved and business models}

About $80 \%$ of palm oil is used for food including chocolate confectioneries, margarine, frying fats and cooking oil; the rest is used for non-food applications including straight vegetable oil, fuel, soaps and drilling lubricants (Lopez and Laan 2008). Carotech, FIMA-MPOB, Greenbiofuels Loreno, Mission Biofuel, PGEO Bioproducts and Vance Bioenergy Weschem Technologies are companies that are already producing biofuels in Malaysia (Lopez and Laan 2008). They are either vertically integrated, such as Golden Hope/Sime Darby, or independent producers such as Carotino Sdn, Bhd.

\section{Socioeconomic impacts}

Conflicts between native people claiming customary rights over lands, and imposed development schemes have long been a problem in Sarawak. At least 40 cases of disputes between oil palm and native communities are registered in the Sarawak courts (Colchester et al. 2007). Forest-dependent people, such as the nomadic Penan communities in Sarawak, have been in a long conflict with timber and oil palm companies. Their claims over territorial boundaries and their traditional land rights are often denied. Some reserve areas promised for Penan communities have no legal basis and have never materialised. Forests on which the Penan community depend have been heavily logged by the timber and plantation concessions, making the community even more impoverished than ever (Milieudefensie et al. 2008). 

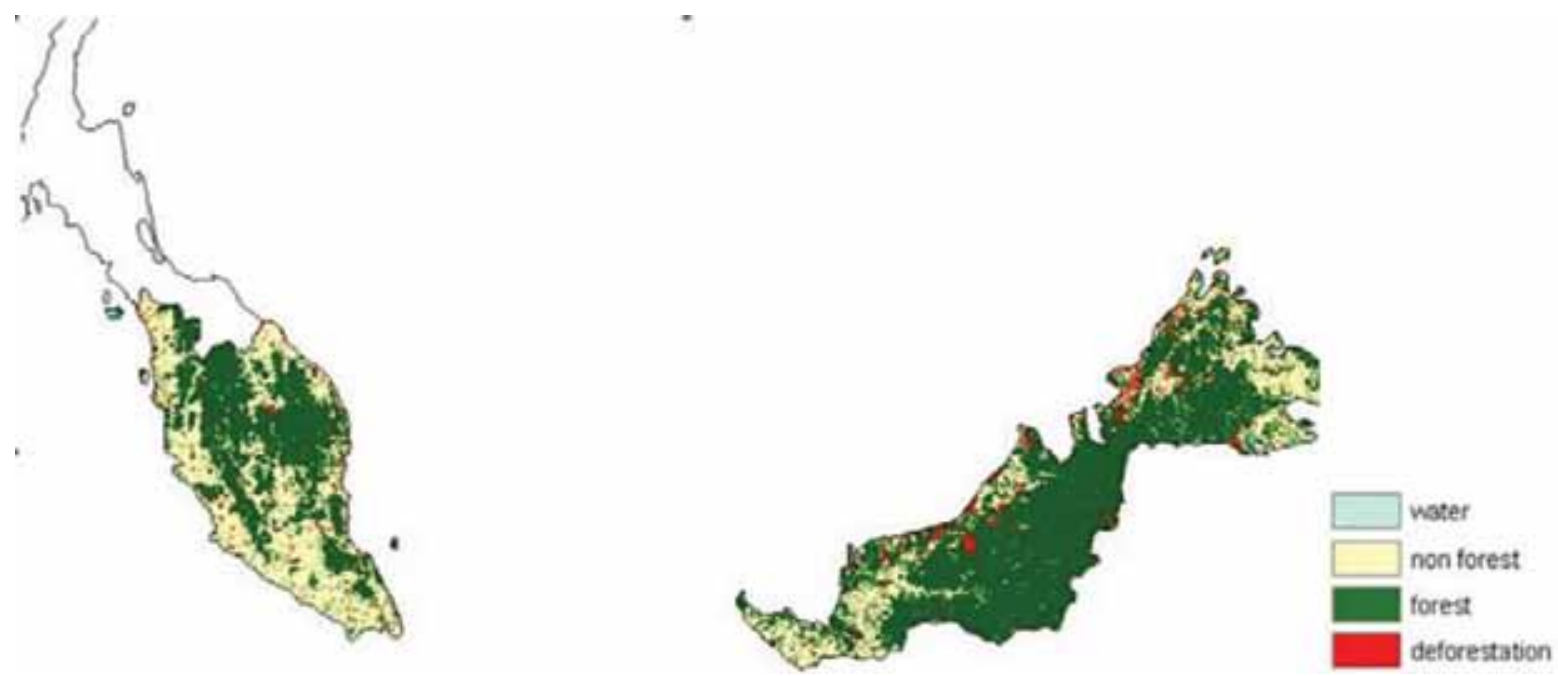

Figure f. Deforestation hotspots in Malaysia from 1999 to 2006

Source: SPOT vegetation (WWF-SAR Vision) 1999-2006, $1 \mathrm{~km}$ spatial resolution

Most Penan communities have to accept the direct consequences of the oil palm plantations' establishment. The communities have not been consulted on the development plan by any government department or officials, or by the company's employees (Colchester et al. 2007). In some cases, the company paid the community a customary fee; however, in many cases the communities have to wait for several months or even years for recompense for any crops damaged and customary lands occupied by the companies.

\section{Environmental impacts}

A report by Milieudefensie et al. (2008) indicated that between 1990 and 2005, the total new area opened up for oil palm plantations was 929000 ha, which nearly matches the reported natural forest cover loss over the same period (913 $000 \mathrm{ha}$ ). It can be argued that a large share of Malaysian deforestation can be attributed to oil palm expansion (Figure f).

It should be noted, however, that part of the oil palm plantation expansion has also been on former rubber, and coconut plantations. In the state of Sarawak, peat swamp forests are targeted for expansion and at least 400000 ha of Permanent Forest Estates were allocated for conversion into agriculture plantations, mostly oil palm (Milieudefensie et al. 2008). In 2009, total biodiesel production in Malaysia reached 0.5 million tons out of 17.7 million tons of oil palm production, or $2.8 \%$ of the total. Assuming pessimistically that all oil palm plantations have been expanding on native forests, we can then estimate that $2.8 \%$ of total deforestation in Malaysia comes from biodiesel production.

\subsection{Oil palm expansion and biodiesel development in Colombia}

\section{Introduction}

Palm oil was introduced in Colombia around the 1970s in relatively small areas, and evolved by supplying oil to the domestic market. The planted areas began growing in the mid-2000s in response to government expansion incentives to supply enough oil to achieve blending targets for biodiesel production (5\% in 2008). In 2004, the total area under oil palm was equivalent to 238926 ha, and reached 336956 ha in 2008 (FEDEPALMA 2009). The 2008 figure gives Colombia the largest oil palm area in Latin America, followed by Ecuador, Honduras and Brazil.

\section{Production dynamics}

Oil palm is expanding in four different regions in Colombia (Figure g). The largest production area is located in the eastern zone (121 $135 \mathrm{ha}$ ) followed by the northern zone (106 $635 \mathrm{ha}$ ), the central zone (87 $525 \mathrm{ha}$ ), and finally the western zone (21 661 ha) (FEDEPALMA 2009). It is noteworthy that 


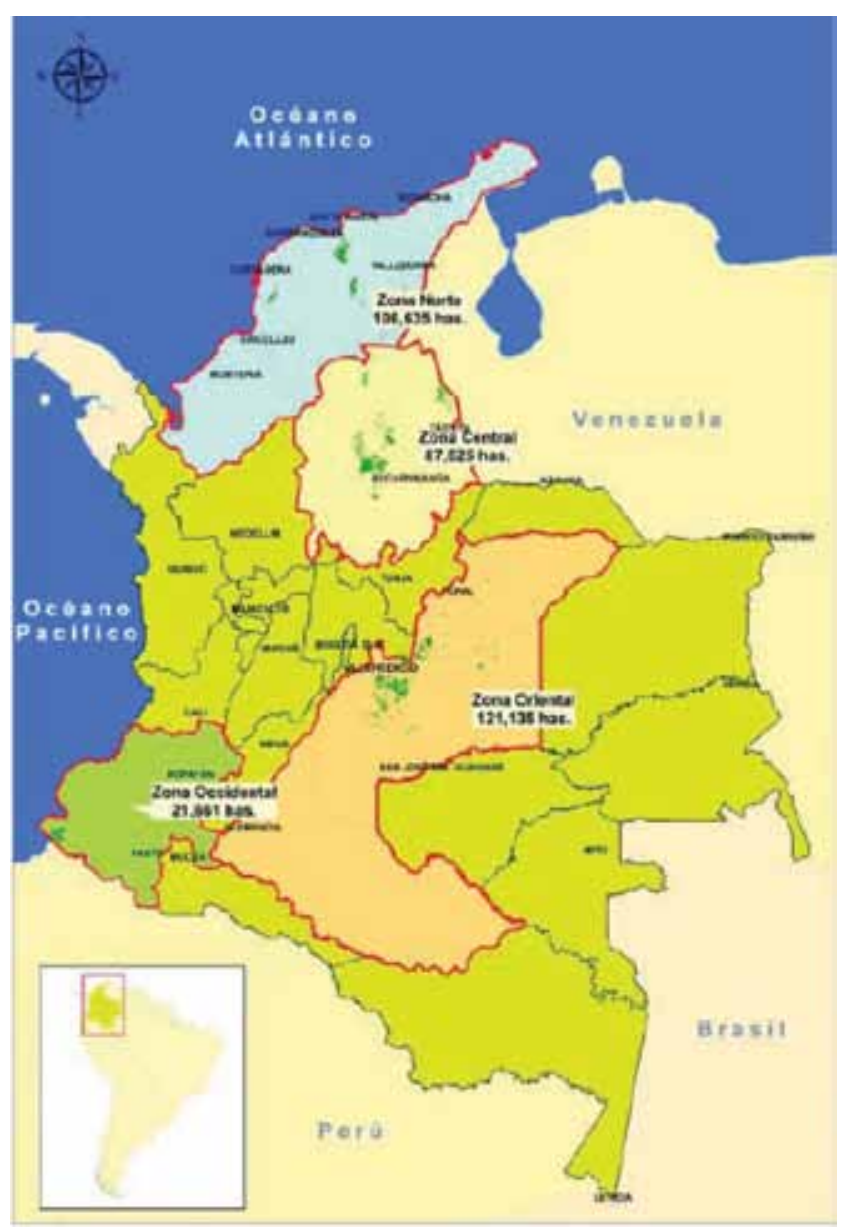

Figure g. Location of oil palm production zones in Colombia

Source: FEDEPALMA (2009)

the largest expansion is occurring in the western zone where more land is available, followed by the northern and eastern zones. In the last 2 years, more than 16700 ha have been lost in the western zone due to bud rot disease. In this same period, the presence of low-yield palm (including both young and very old palms) in the production area has increased significantly in the northern and eastern zones. The average fruit yield per ha was 17.9 tonnes in 2007 and 16.8 tonnes in 2009 (FEDEPALMA 2009).

In Colombia, there are plans to significantly expand the area covered by oil palms, mainly to supply the biodiesel market, though the global economic crisis has affected investment plans for expanding the oil processing capacity. In spite of that, as of today, seven plants are producing biodiesel with a total capacity of 516 tonnes per year, from a total planted area of 114999 ha (Vera 2009). It is noteworthy that the Plan for Biodiesel Development in Colombia (DNP
2008) defines a goal of 2 million ha to meet the national demand for biodiesel in 2019, equivalent to 3.2 million litres per day at a blending target of $10 \%$ (DNP 2008). Discussion is ongoing about how much land is suitable for oil palm production in Colombia since the last assessment in 1999. Several institutions are currently undertaking another evaluation.

Oil palm expansion in recent times is largely an outcome of state incentives, which have led some investors to acquire less productive land (mainly in pasture use) to expand the oil palm plantations. Main incentives introduced in the policy framework have been tax holidays (Law No. 788/2002 and Law No. 939/2004), implementation of free tax zones (DS. No. 383/2007), tax reductions from investments in productive assets (Law 111/2006) and credit incentives from implantation and maintenance of plantations (Programa Agro Ingreso Seguro). The latter include special credit lines and ICR. However, these incentives have been applied to the agricultural sector as a whole, including perennial crops (e.g., oil palm, cocoa, rubber).

According to DNP (2008), biofuel production (including both bioethanol and biodiesel) benefited by at least about US $\$ 410$ million from these different incentives, mainly tax holidays and subsidised credit. However, the most determinant policy decision to support biodiesel expansion was a 5\% blending target by 2008 for the whole country, which has created a niche market for biofuel production supplied by the largest biodiesel companies. Furthermore, in Colombia, the state controls biodiesel prices, which are determined as the maximum value between estimated production costs considering some efficiency standards, and the price of imported diesel plus the cost of progressing palm oil into biodiesel.

\section{Companies involved and business models}

In 2008, 55 mills were operating for oil palm production in Colombia, out of which 28 are relatively small (less than 15 tonnes fresh fruit bunches (FFB)/hour), 15 are medium size (from 15-25 FFB/hour), and 13 have a capacity larger than $25 \mathrm{FFB} /$ hour. Among the latter, only two plants have a capacity equivalent to 60 tonnes $\mathrm{FFB} /$ hour, one in Villanueva, Casanare (owned by Palmar del Oriente SA and Extractora del Sur de Casanare) and another in San Alberto, César (owned by Indupalma SA). 
While most oil palm plantations are in the hands of vertically integrated private companies, an estimated $40 \%$ of the total area under cultivation corresponds to plantations of less than 10 ha; these have expanded as a result of outgrowing schemes put in place by some companies. It is noteworthy that, as well as in some other sectors, the oil palm sector has developed many small-scale cooperatives that provide numerous services to the large-scale plantations (planting, weeding, harvesting and transportation). In 2008, 775548 tonnes of palm oil and 178302 tonnes of palm kernel oil were produced. Domestic palm oil sales equated 452752 tonnes and 323992 tonnes were exported. Domestic sales increased by 22931 tonnes in 2008, due to the new market for biodiesel production, which absorbed 39736 tonnes, or $5 \%$ of oil produced (FEDEPALMA 2009).

\section{Socioeconomic impacts}

The social implications of oil palm plantation development are being debated in Colombia, although it may vary depending on the different regions. Some argue that oil palm plantations are linked to encroachment on community lands by paramilitary movements, which legitimise property rights that are further usufruct by private companies. Others argue that oil palm production tends to create more jobs than displace local people, to the extent that plantations are mainly established on lands that were pasture previously occupied by extensive cattle ranching that had little demand for rural employment. Nonetheless, a distinction should be made between the oil palm planted by paramilitary groups, which are a legacy of a long tradition of violence in Colombia and which tend to use oil palm as part of a broader strategy to settle presence in the territory, and the plantations being developed by corporate actors, which have even condemned paramilitary actions to preserve their own image. The debate, however, tends to confound these two situations.

Two perspectives on the social conflicts have emerged. For example, oil palm expanding along the Pacific coast tends to threaten the community land rights of the Afro-Colombian communities settled there. In other cases, as already mentioned, oil palm is planted to justify land ownership on land previously occupied by displaced people, particularly in the central and northern zones. The latter is due to unclear tenure rights in Colombia and the lack of working institutions to formalise such rights. Yet the significance of oil palm plantations in displacing people is unclear, since coca plantations also play a significant role in land displacement. In areas such as in Tumaco, coca and oil palm plantations coexist (Rangel et al. 2009). As noted earlier, oil palm plantations are also expanding in the western zone, often over pasture and on lands controlled de facto by large-scale ranchers, who often sell their land to oil palm companies; this might be prompting some land speculation in the area.

\section{Environmental impacts}

With the exception of some areas in the western and northern zones, most oil palm expansion is taking place on grasslands and implanted pasture. The main expansion zones are the grasslands located in the Orinoquia, in the eastern zone. Therefore, oil palm plantations are currently not driving most forest clearing taking place in Colombia, which is still driven by pasture expansion (Etter et al. 2006). Although some pasture lands are being converted to oil palm, there is no clear process of indirect land use change, given the relatively low productivity of converted pastures and a simultaneous process of cattle ranching intensification across the country. Further research is needed on this topic.

\subsection{Soybean expansion and biodiesel development in Mato Grosso, Brazil}

\section{Introduction}

Soybean has been expanding significantly in the state of Mato Grosso (Figure h) in the southern portion of the Brazilian Amazon since the mid-1980s. This growth has been mainly driven by the availability of cheap land, much of which is forests, increasing public investment in roads to connect the region to main markets and exports, and access to technology that allows soy to grow in both the Cerrado region and tropical areas. These conditions have favoured the arrival of some of the largest grain trade companies (for example, Cargill, Bunge and Archer Daniels Midland), with important investment in processing and transportation facilities, thus making possible the integration of the agricultural frontier with the major international markets. Although meal and cake are the main soybean products due to greater interest from food and feed markets, oil production has become relevant with expanding internal demand 


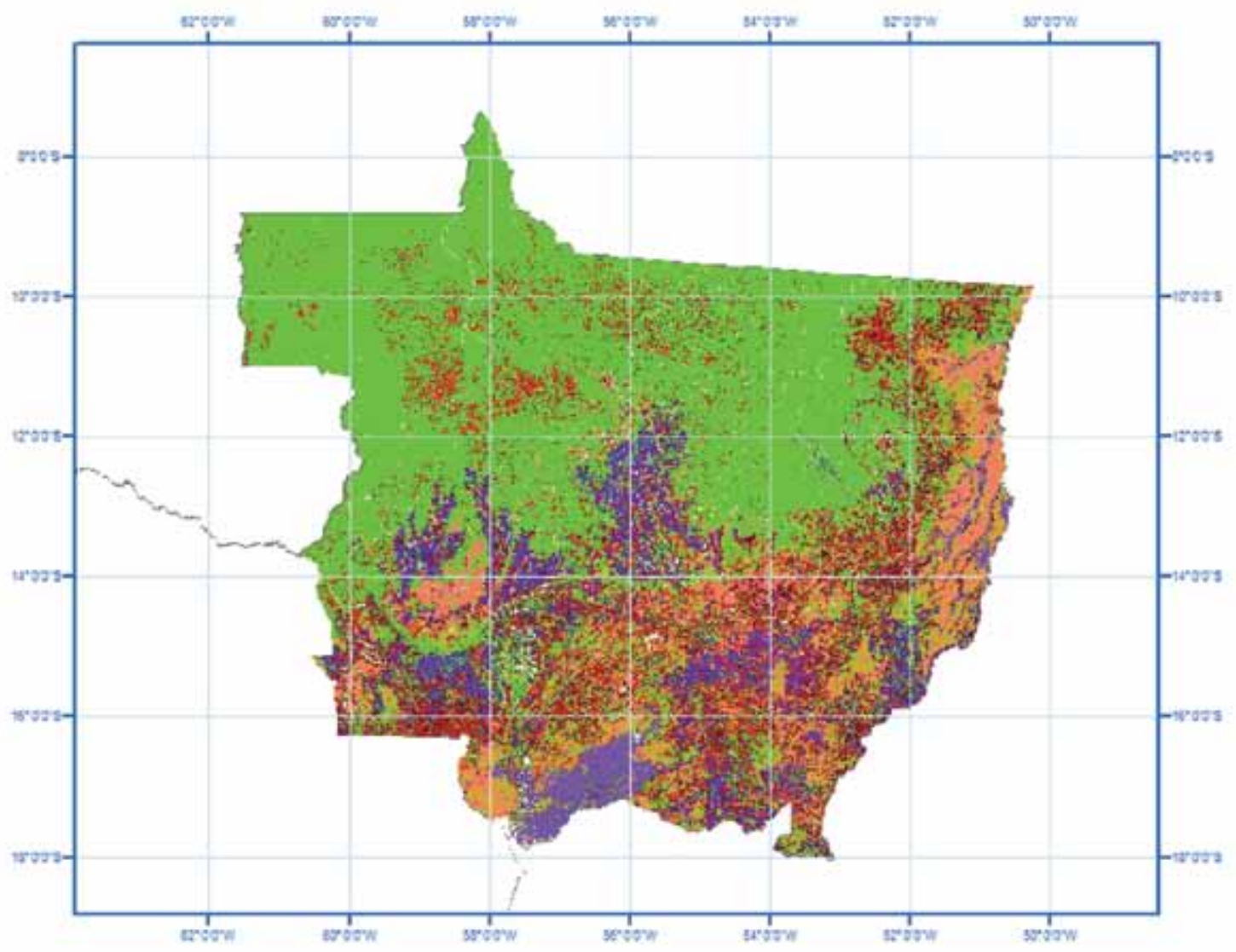

\section{Legend}

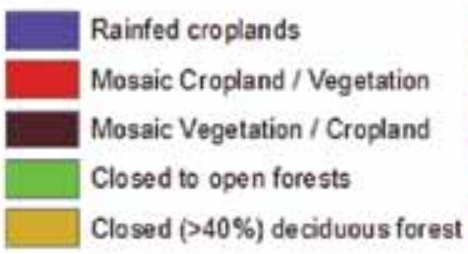

0.62 .5125

$250 \quad 375 \quad 500$

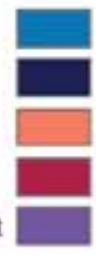

Open (15-40\%) deciduous forest

Mosaic Grassland / Forest / Shrubland

Closed to open / shrubland

Closed to open / grassland

Closed to open / Vegetation

Figure h. Location of Mato Grosso State in Brazil

for biofuel production. Thereby, capital has been invested to expand the biodiesel processing capacity, creating an additional incentive for the agribusiness sector (BWC 2008).

\section{Production dynamics}

Soybean was first planted in the 1980s, although the real boom began in the 1990s (Jasinski et al. 2005). Between 1995 and 2004, the area cultivated with soybean increased by $77 \%$ in the centre west of Brazil, with Mato Grosso becoming the single biggest producer (McCarthy and Buncombe 2005). Most soybean has been planted in the Cerrado area. From
2004 to 2008 , soybean production had increased by $19.6 \%$ (IBGE 2009) from 14.5 to 17.2 million tons (Table c), peaking with high international soy prices in 2005.

No reliable estimates exist for the proportion of soybean production in the state dedicated to biodiesel production, but Hall et al. (2009) estimate that $21 \%$ of the soy oil produced in Brazil would have been needed to meet national targets for the fuel mix (3\%) in 2008. The mix increased to 5\% in 2010, and applying Hall's method this would mean that $35 \%$ of the soy oil would be needed. This is an overestimate since Hall et al. (2009) 
Table c. Soybean production in Mato Grosso

\begin{tabular}{lccccc}
\hline \multirow{2}{*}{ Soybean production (million tons) } & 2004 & 2005 & 2006 & 2007 & 2008 \\
\cline { 2 - 5 } & 14.5 & 17.8 & 15.6 & 15.3 & 17.2 \\
\hline
\end{tabular}

Source: IBGE (2009)

assumed that only soy would be used to produce biodiesel when, in fact, at present only $76 \%$ of total biodiesel production is from soybean oil, although this is expected to rise to $90 \%$ in the next 10 years (Wilkinson and Herrera 2010); the rest is from sunflower, jatropha and other oil bearing plants (ANP 2009). It should be noted that oil represents only $18 \%$ by weight of the soy bean, the rest (cake) being used mainly for cattle feed. Around 16-20\% of deforestation in Mato Grosso is due to cultivation, the rest is due to clearance for grazing (Morton et al. 2006; Nepstad et al. 2009) and 84\% of the cultivation area is devoted to soy (Wright 2009), not taking into account double cropping.

Using this data, Table d estimates the burden of biodiesel in the total deforestation of Mato Grosso, using three different modes of calculation: on the basis of the relative weight of the soy oil in the total soy production (line J1); on the basis of the relative economic value of the soy oil in the total soy production (line J2); and on the basis of the total soy production itelf (line $\mathrm{K}$ ). This indicates that biodiesel may be directly responsible for a maximum of $5.9 \%$ of the deforestation observed in Mato Gross, although it could be as low as $0.8 \%$.
The Brazilian Ministry of Agriculture (MAPA 2008) forecasts a total soybean harvest equivalent to 75.3 million tonnes by $2017 / 18$, from 25.6 million ha of land, with an average yield of 2.9 tonnes per ha for Brazil as a whole. This source estimates an area expansion factor of 1.16 (adding 3.6 million ha) and a production increase factor of 1.44 (adding 23.1 million tonnes). This plan implies increasing the production of soybean in Mato Grosso as well, which would imply further pressure on surrounding forests. As of late 2008, there were 18 biodiesel plants operating in Mato Grosso; another 16 are in the process of implementation and three more are planned. Significant investment is being allocated to the state to expand the biodiesel processing capacity.

As mentioned, the comparatively low price of land is the main expansion driver for soybean in Mato Grosso. The vast majority is cultivated in the Cerrado although some is in the Amazon biome. Expansion was facilitated by improved accessibility to land due to growing public investment in roads, and motivated by a high international demand for soybean.

Additional internal demand in Brazil has also played a role, as has the possibility of significant profits given current price levels relative to other economic

Table d. The burden of deforestation due to biodiesel in Mato Grosso

\begin{tabular}{|c|c|c|c|}
\hline & Factor & Estimated loss (\%) & Source/notes \\
\hline A & $\begin{array}{l}\text { Forest clearance attributable to cultivation (remaining } \\
\text { clearance is due to grazing) }\end{array}$ & $16-20$ & $\begin{array}{l}\text { Morton et al. (2006), Nepstad et al. } \\
\text { (2009) }\end{array}$ \\
\hline B & $\begin{array}{l}\text { Soy as percentage of total cultivation area (ignoring } \\
\text { double cropping) }\end{array}$ & 84 & Wright (2009) \\
\hline C & Oil as percentage of soy crop, by weight & 18 & \\
\hline D & Oil as percentage of soy crop, by market value & 42 & $\begin{array}{l}\text { Based on 3:1 ratio of } \$ / \text { tonne } \\
\text { (World Bank 2008) }\end{array}$ \\
\hline$E$ & $\begin{array}{l}\text { Percentage of soy oil required to meet Brazil's biofuel } \\
\text { blending targets }\end{array}$ & 35 & Hall et al. (2009) \\
\hline $\mathrm{F}$ & Forest loss due to soy & $13.4-16.8$ & $A \times B$ \\
\hline G & Forest loss due to soy oil, by weight & $2.4-3.0$ & $\mathrm{~F} \times \mathrm{C}$ \\
\hline $\mathrm{H}$ & Forest loss due to soy oil, by $\$$ value & $5.6-7.0$ & $\mathrm{~F} \times \mathrm{D}$ \\
\hline$J$ & $\begin{array}{l}\text { Range of estimates of forest loss due to biodiesel based } \\
\text { on weight and } \$ \text { values }\end{array}$ & $0.8-2.6$ & Min $\mathrm{G} \times \mathrm{E}, \mathrm{Max} \mathrm{H} \times \mathrm{E}$ \\
\hline $\mathrm{K}$ & $\begin{array}{l}\text { Alternative estimate of forest loss due to biodiesel, based } \\
\text { on economic inseparability of soy oil and soil meal }\end{array}$ & $4.6-5.9$ & $\begin{array}{l}\mathrm{F} \times \mathrm{E} \text {; burden calculated on total soy } \\
\text { crop, not on oil only. }\end{array}$ \\
\hline
\end{tabular}


activities. All these conditions have facilitated the arrival of international companies for trading and processing, and prompted the creation of one of the biggest agribusiness corporations constituted with Brazilian capital (Grupo André Maggi).

The percentage of feedstock that goes to biofuel production is decided by the processing companies and the markets, not the soybean producers. The proportion varies from year to year, or even from season to season, depending on relative market prices of soy oil as a food commodity and biofuel.

\section{Companies involved and business models}

Large-scale companies dominate soybean and biofuel production. Several companies are involved in soybean plantation and biodiesel production, including Archer Daniels Midland (ADM) and Grupo Maggi. ADM is the world leader in processing agricultural goods and fermentation technology. It is one of the two major world processors of soybean, maize, wheat and cacao. ADM started to produce biodiesel from soybean at the end of 2007. It produces 565000 litres of biodiesel per day. Grupo Maggi is the world's largest individual soybean producer. It is estimated that this group is responsible for more than $17 \%$ of the soybean that grows in Mato Grosso. Other large transnational corporations operating in the state are Cargill and Bunge.

\section{Socioeconomic impacts}

The effects of soybean production are manifold and sometimes contradictory. On the one hand, soybean sector growth has reportedly been generating direct and indirect jobs and income, and some urban centres in municipalities where soybean is growing have shown important development. However, soybean production creates relatively fewer direct jobs because it involves large-scale and capital-intensive activities. While job creation numbers are likely higher than in cattle ranching, fewer jobs can be expected where soybean displaces traditional cultivation activities (BWC 2008). Furthermore, soybean contributes to expanded earnings for the State and municipalities, and helps create employment at the regional level, thus it has a significant impact on economic growth.
The main conflicts from soybean plantation and expansion are land-related since soybean plantation is profitable only at medium and large scales; this also demands the availability of significant capital to finance the cultivation. It also implies the concentration of profits in a small group of large enterprises. The crop is totally mechanised, which means that only a few companies with relatively specialised labour can attend large plantation areas. It should be stated that the economic activity brought about by the crop helps create more jobs in nearby cities, so there is a tradeoff between the concentrations of benefits and spill over effects in the regional economy at large. No figures are available to accurately assess the number of people who have been bought out from small landholdings by large cultivators, and what happened to them is uncertain. Many have found employment in the tertiary sector in the towns that service the soy business, but undoubtedly others have moved on to other sites to start small-scale farming elsewhere.

\section{Environmental impacts}

Soybean production has expanded mainly in the Cerrado, but also in the wet tropical forests areas in Mato Grosso. Mato Grosso has the highest deforestation rate within Brazil (Figure i), and twothirds of the deforestation in the past was illegal (Morton et al. 2006). In 2004, more than 10000 square miles—nearly the size of Belgium — was cut down, with half the destruction in Mato Grosso. A report mentions that by 2003 more than $20 \%$ of forests in Mato Grosso had been converted to soya plantations (Morton et al. 2006). As we estimate that a maximum of $35 \%$ of soy oil might be converted to biodiesel in Brazil, this means that $1.5-7 \%$ of the deforestation can be attributed to biodiesel production, depending on the method used to allocate the deforestation burden (see main text for the calculations).

While a portion of soybean expansion leads to direct deforestation, another portion occurs in lands already deforested, often under degraded pasture. Morton et al. (2006) indicate that the forest area converted directly to large-scale crop production in Mato Grosso during 2001-2004 ranged from 785 to $2150 \mathrm{~km}^{2}$ per year. An important portion of 

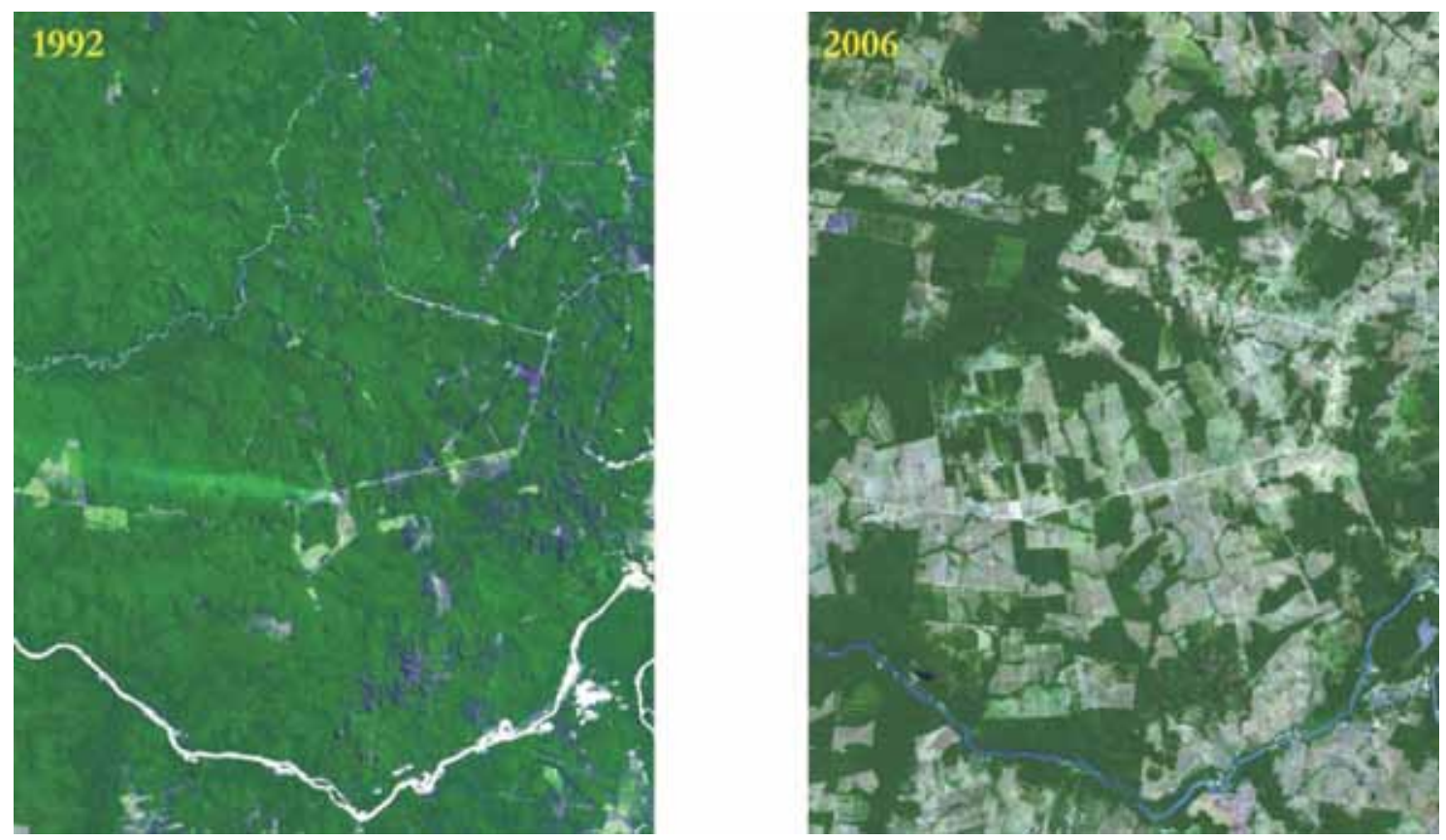

Figure i. Forests in Mato Grosso converted to agricultural land. The left image is Landsat TM from 1992; the right side is ASTER (advanced spaceborne thermal emission and reflection radiometer) from 2006.

Source: Jet Propulsion Laboratory, NASA

soybean expansion occurred on pasture areas, rapidly displacing cattle ranching in these areas (FBOMS 2005), particularly north of the main soy growing areas in the Amazon biome.

\subsection{Jatropha expansion for biodiesel production in Brazil ${ }^{25}$}

According to a 2008 study of the global jatropha market, Brazil is poised to become one of the world's top three cultivators by 2015. Based on company surveys and interviews with industry experts, a near 75-fold increase in jatropha cultivation between 2008 and 2015 is predicted (from about 17500 ha to 1.3 million ha). The main drivers are Brazil's biodiesel program and increased global demand for jatropha, particularly from the aviation industry.

Hoping to match its success in establishing a domestic ethanol industry, in 2004 the Brazilian Government enacted the National Program on Production and Use of Biodiesel (PNPB) to catalyse

25 Compiled by Jennifer Baka and Robert Bailis, Yale School of Forestry and Environmental Studies. the biodiesel industry. The program established mandatory biodiesel blending targets of $2 \%$ starting in 2008 and 5\% starting in 2013 (Pousa et al. 2007). Further, the program established a biodiesel Social Fuel Stamp (Selo Combustivel Social) to promote the inclusion of smallholders from poorer regions. The program requires biodiesel producers to purchase certain percentages of their feedstocks from family farmers, varying from $10-50 \%$ depending on cultivation location. Additionally, the producers must sign commercial contracts with farmers and provide technical assistance. By receiving the stamp, producers gain the opportunity to participate in government-sponsored auctions in which Petrobras, the country's semi-public oil company, guarantees the purchase of biodiesel. As well, producers qualify for tax exemptions depending on the location of feedstock purchases, ranging from $4-12 \%$ of the commercial diesel price (Hall et al. 2009; Garcez and Vianna 2009). Producers earn the largest tax exemptions by purchasing castor or palm oil feedstocks from family farmers in the north or northeast, the poorest regions of the country. Although well intended, the Social Fuel Stamp program has experienced a lack of demand and at 
present, Petrobras has waived its requirement to only allow producers who receive the stamp to participate in its auctions (Hall et al. 2009).

To date, jatropha does not qualify for the Social Fuel Stamp because jatropha is not recognised as a cultivar under the PNPB. However, the Government's agricultural research agency, EMBRAPA (Empresa Brasileira de Pesquisa Agropecuária), is currently sponsoring research and development trials to evaluate the feasibility of using jatropha for biodiesel production (Durães 2009). Additionally, the Brazilian Jatropha Growers Association (ABPPM) has been established to further stimulate the industry and promote the inclusion of jatropha in the Government's biofuel programs.

Continued international demand is another factor promoting the jatropha market in Brazil. Jatropha trees are capable of growing on marginal land, thus potentially avoiding competition with food production and reducing land use change impacts. As such, jatropha has received increased attention from various governments, development agencies, biofuel roundtables and industries seeking to promote the use of sustainable biofuels. The aviation industry has been a key promoter as numerous airlines, starting with Virgin Atlantic in February 2008, have conducted biofuel test flights using jatropha (Hileman et al. 2009).

Within Brazil, stakeholders are particularly interested in situating jatropha projects in the centre-west, northeast and southeast regions because of favourable climatic conditions (GEXSI 2008a). Based on our interviews with key stakeholders, companies are targeting regions with large areas of degraded cattle pasture, specifically in the states of Tocantins, Minas Gerais and Bahia. The jatropha market is still in its infancy in Brazil and companies are engaged in a mix of plantations and contract farming operations to cultivate it. However, efforts are underway to mechanise jatropha cultivation, particularly harvesting, to increase the scale of production and avoid Brazil's relatively high labour costs ( $\$ 15$ per day) and strict labour laws. If mechanisation is successful, it will likely lead to an increase in number and size of jatropha plantations to achieve economies of scale and reduce production costs.
During the summer of 2009, a research team from the Yale School of Forestry and Environmental Studies, with funding from the Sustainable Aviation Fuel Users Group (SAFUG), surveyed jatropha farmers in Minas Gerais to evaluate the potential land use change impacts of jatropha cultivation (Figure j). ${ }^{26}$ To examine the potential land use change impacts of jatropha, the team surveyed farmers about the land use history of the sites where they are (were) growing jatropha. Approximately $63 \%$ of the farmers used to grow crops or graze animals where they decided to plant jatropha. More specifically, farmers reported 53 instances of replacing other crops with jatropha and 11 instances of discontinuing animal grazing (However, only in $40 \%$ of the cases was this related to a farmer's decision to cultivate jatropha) (Table e).

\section{Links to deforestation}

In summary, there is some evidence of competition between jatropha cultivation and crop production and animal grazing, based on an analysis of farmer cultivation decisions. On the whole, farmers at the two sites in Minas Gerais are planting jatropha on cultivable land. More than $60 \%$ of farmers surveyed reported discontinuing crop cultivation or animal grazing on the land where they cultivated jatropha. These findings indicate jatropha cultivation could increase deforestation rates if new lands are cleared to replace crops and animals displaced by jatropha cultivation. However, at present, the jatropha market in Brazil is too young to make definitive conclusions on the links between jatropha cultivation and land use change.

Based on interviews with key stakeholders in Brazil, the industry hopes to establish plantations

26 The team surveyed 58 total farmers $(55$ men and three women) in northern and southern Minas Gerais (38 northern, 20 southern). The 58 farmers cultivated just over 87 ha with jatropha, with an average of 1.5 ha per farmer. Although this is a small area, it is important to reemphasise the industry's young age in Brazil on the whole. Of the farmers surveyed, 23 continue to cultivate jatropha while 35 have stopped growing it. We refer to these farmers in our analysis as participating and abandoned farmers, respectively. Farmers started planting trees between 2004 and 2008; cultivation started earlier in southern Minas than in northern Minas. At present, jatropha trees for participating farmers are just under 3 years old and have thus not reached maturity as jatropha trees typically take 3-4 years to achieve maximum yields. Many of the abandoned farmers expected jatropha to 'take care of itself' and abandoned the trees after realising the maintenance required. 


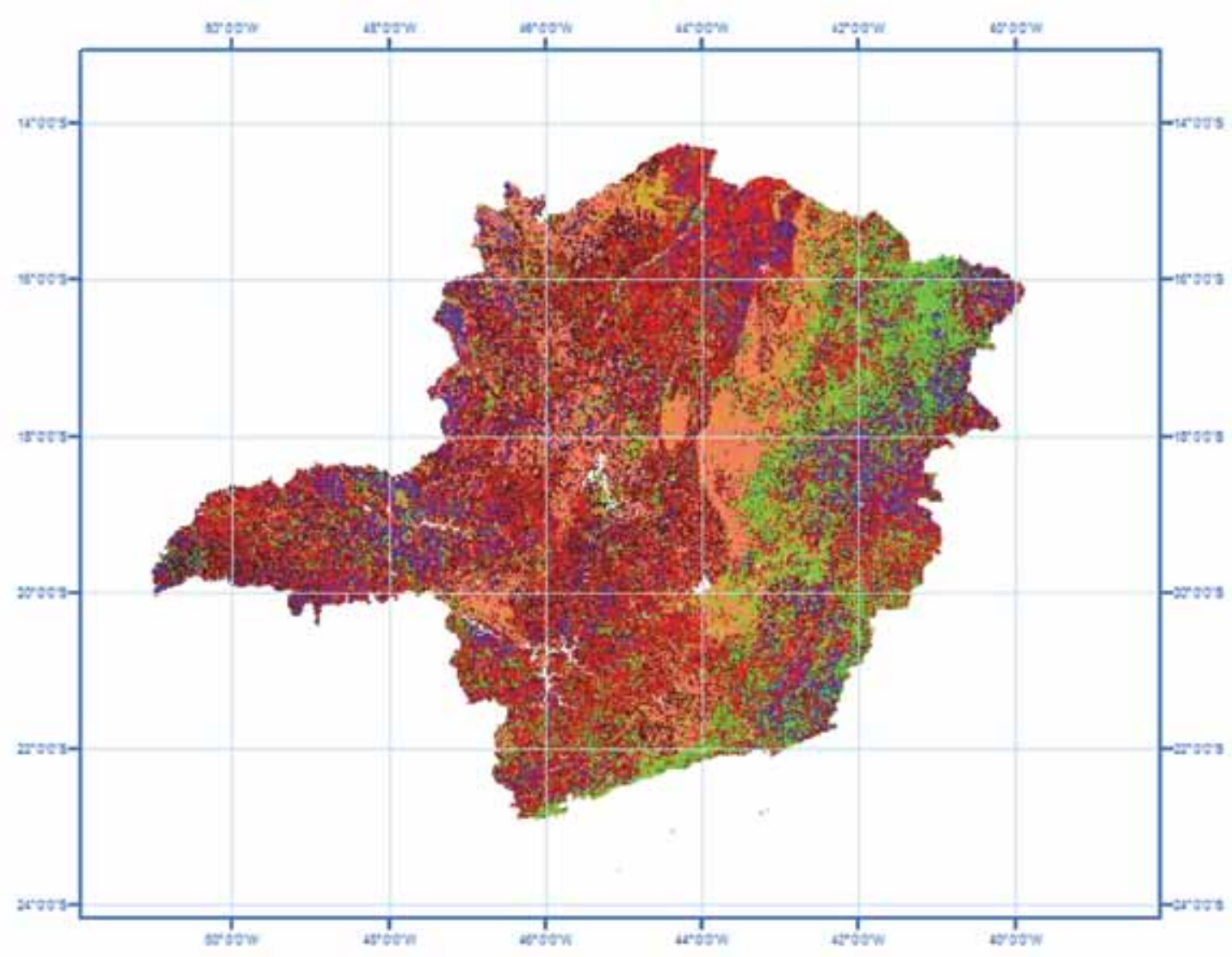

\section{Legend}
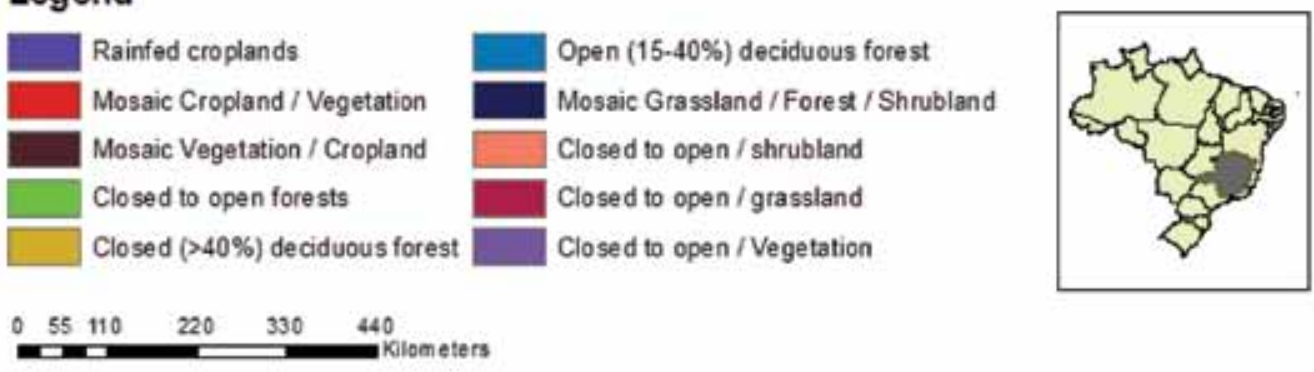

Figure j. Location of Minas Gerais State in Brazil

Table e. Prior land use decisions, farmer location and status

\begin{tabular}{|c|c|c|c|c|c|}
\hline & \multicolumn{2}{|c|}{ Northern Minas } & \multicolumn{2}{|c|}{ Southern Minas } & \multirow{2}{*}{$\begin{array}{c}\text { TOTAL } \\
\text { All } \\
\% \text { (\#) }\end{array}$} \\
\hline & $\begin{array}{c}\text { Participating } \\
\%(\#)\end{array}$ & $\begin{array}{l}\text { Abandoned \% } \\
\text { (\#) }\end{array}$ & $\begin{array}{c}\text { Participating } \\
\quad \%(\#)\end{array}$ & $\begin{array}{c}\text { Abandoned } \\
\%(\#)\end{array}$ & \\
\hline Grew other crops & $71 \%(12)$ & $57 \%(12)$ & $4 \%(2)$ & $14 \%(2)$ & $49 \%(28)$ \\
\hline Grazed animals & $0 \%(0)$ & $0 \%(0)$ & $0 \%(0)$ & $50 \%(7)$ & $12 \%(7)$ \\
\hline Nothing & $29 \%(5)$ & $43 \%(9)$ & $50 \%(3)$ & 36\% (5) & $39 \%(22)$ \\
\hline Other & $0 \%(0)$ & $0 \%(0)$ & $0 \%(0)$ & $0 \%(0)$ & $0 \%(0)$ \\
\hline TOTAL & $100 \%(17)$ & $100 \%(21)$ & $100 \%(5)$ & $100 \%(14)$ & $100 \%(57)$ \\
\hline
\end{tabular}

Source: Yale SAFUG Brazilian Farmer Survey, summer 2009 
on degraded cattle pasturelands as the industry matures. This could reduce threats to deforestation if establishing such plantations does not displace other farming activities. Yet locating the industry on degraded cattle pasturelands can still increase the environmental impacts of jatropha cultivation depending on the biomass content of such lands. Moreover, while Brazilian biofuel policy targets production on degraded pasture, and key players in the biofuel industry stress the great distance between biofuel production areas and the country's rich tropical forests (UNICA 2008), several researchers have noted the complex interconnections between agriculture in the Cerrado region, cattle production, and deforestation (Nepstad et al. 2006; Sawyer 2008). The introduction of jatropha, if it takes off, is likely to shift that dynamic. However, it is too early to guess whether that will lead to increasing or decreasing pressure on Brazil's forest areas. Thus, it is imperative to closely monitor the jatropha industry in Brazil as it matures.

\subsection{Jatropha expansion for biodiesel production in India ${ }^{27}$}

As one of the earliest promoters of jatropha for biofuel production, India is the world's leading grower with over 400000 ha under cultivation, which represents approximately $45 \%$ of global production (GEXSI 2008b). Presently, India uses fossil fuels to meet more than $95 \%$ of the country's transportation needs (GOI 2003). Because of limited and rapidly depleting domestic sources, India currently imports close to $80 \%$ of its fossil fuel resources (GOI 2003). As result of its increased dependency and expenditures on fossil fuel imports, in 2003, the Government of India announced plans for a National Mission on Biodiesel to displace $20 \%$ of diesel with jatropha biodiesel by 2012 (GOI 2003).

Although the plan was not codified at the time, interest in jatropha rapidly accelerated after the announcement as various states implemented jatropha biodiesel blending mandates and numerous domestic and international companies established projects throughout the country. Efforts at the

27 Compiled by Jennifer Baka and Robert Bailis, Yale School of Forestry and Environmental Studies. national level stalled mainly because of political difficulties, including administration changes and infighting among ministries as to who would control biofuel development programs. However, in December of 2009, the Government enacted a National Policy on Biofuels (MNRE 2009). The Ministry of New and Renewable Energy will implement the policy while a newly formed body headed by the Prime Minister, the National Biofuel Coordination Committee (NBCC), will oversee the policy (MNRE 2009). The policy established a blending target of $20 \%$ by 2017 for both biodiesel and ethanol, subject to periodic revision (MNRE 2009).

While the current policy does not specifically recommend the use of jatropha biodiesel, the feedstock conditions laid out by the policy strongly imply resurgence in jatropha activity throughout the country. The policy states only 'non-edible oilseeds grown on wasteland, degraded or fallow land in forest and non-forest areas' should be used for biodiesel production (MNRE 2009:7). These conditions, the Government stipulates, sets India's biofuel program apart from other international efforts because they help to ensure biofuel production does not interfere with food production. Jatropha achieved prominence in the global biofuels debate because of its alleged ability to grow in degraded areas away from food cultivation and it will undoubtedly play a key role in India's biodiesel industry.

The Government will provide a variety of support to help stimulate the biofuel industry. It will establish a minimum support price for oilseeds to promote contract farming and it will also provide financing to farmers and biodiesel producers through the National Bank of Agriculture and Rural Development (NABARD). Further, companies establishing oilseed plantations on degraded lands will be eligible to participate in the National Rural Employment Guarantee Program (NREGP) to subsidise the cost of labour. Finally, the Government hopes to earn carbon credits and attract development assistance to successfully carry out the program.

The southern state of Tamil Nadu has been at the centre of India's jatropha industry and is sure to feature prominently as the new biofuel policy unfolds. Tamil Nadu is home to the Centre of Excellence in Biofuels, one of the world's leading 
jatropha research centres, located at the Tamil Nadu Agricultural University (TNAU). Currently, TNAU is implementing the state's jatropha program, which aims to cultivate jatropha on 100000 ha by 2012 (TNAU 2009).

Although the program does not target specific lands for cultivation, most activity is concentrated in dryland regions in the state's southern districts. Much of this region is covered in Prosopis juliflora, a drought-tolerant tree planted as part of social forestry programs in the 1960s to provide fuelwood for rural communities (Arnold et al. 1987).

Further, the Western Ghats forest, a biodiversity hotspot according to Conservation International (Conservation International 2009), forms the western border of the region. Companies are attempting to lease contiguous plots of land in these regions to clear Prosopis and establish jatropha plantations. ${ }^{28}$ Researchers at the Yale School of Forestry and Environmental Studies, with support from the Sustainable Aviation Fuel Users Group (SAFUG), assessed the environmental and rural livelihood implications of this transition.

\section{Links to deforestation}

Research is being conducted on how local communities have historically used the lands where jatropha plantations are being established and what threats, if any, these changes pose to the Western Ghats. Such lands are often common property resources used by communities for fuelwood collection and animal grazing. Further, communities also use the Prosopis currently planted on these lands as a charcoal feedstock. If jatropha cultivation restricts access to fuelwood and fodder sites or reduces the availability of charcoal feedstocks, villagers may have to migrate elsewhere in search of these supplies. Additionally, continued demand for biofuels may further increase land use pressures, which might pose additional threats to the Western Ghat forests. Although the jatropha market in this region of south India is in its infancy, the region should be closely monitored in the coming years as India's new biofuel program is implemented.

28 Companies referred to this practice as 'captive farming' in interviews.

\subsection{Jatropha expansion for biodiesel production in Ghana ${ }^{29}$}

\section{Production dynamics}

Although the first trials with jatropha cultivation in Ghana date back to 1999, investors only started developing plantations in earnest from 2007 onwards. Seventeen companies have been identified across Ghana, collectively developing more than 30 large-scale plantations on more than 1 million ha. With the exception of a sugarcane and a cassava plantation, most companies are focusing on jatropha cultivation (though two companies are also growing oil palm as a secondary feedstock) (for the location of those jatropha companies, see Figure k). Although companies claim to have access to vast areas, only a fraction of the acquired land is presently under cultivation. As of August 2009, 7000-8000 ha of land were under jatropha cultivation, approximately half of which was in the three estates of Kimminic Corporation. Other, more advanced plantations include those of Scanfuel and Biofuel Africa. The majority of developments are taking place in the forest transition zone in the regions of Brong Ahafo and Northern Ashanti, where agroecological conditions are suitable and large contiguous areas of land are readily available.

Although numerous companies are constructing industrial-scale processing facilities, only one processing plant in Tema appears to be operational. Since few jatropha plantations are yet seed bearing, the trade and commercialisation of biofuels is negligible. Most jatropha seeds are used for testing and planting purposes only. Some key driving forces behind the rapid development of the Ghanaian biofuels sector are the high availability of land (especially in the central and northern regions), an extremely conducive investment environment, and the ease of obtaining land at highly favourable rates. By and large, biofuel companies are eligible for an array of incentives, such as full repatriation of profits and exemption from income taxes, capital gains, and import/export duties. Furthermore, almost $90 \%$ of Ghana's land cover is under customary tenure and rights, which are secured in statutory law. Most lands are owned by traditional rulers (e.g. chiefs) who typically allocate usufruct rights

29 Compiled by George Schoneveld, CIFOR. 


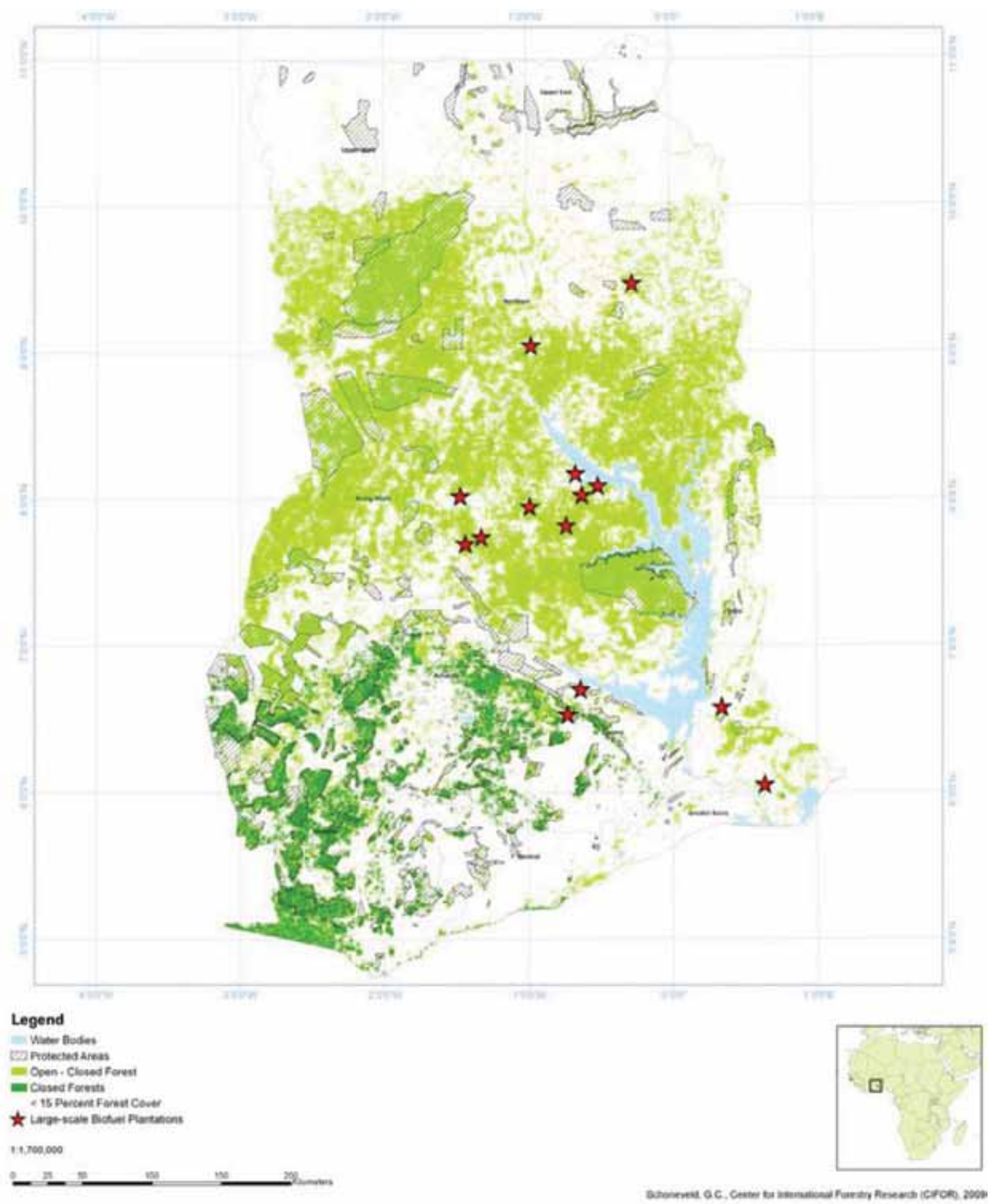

Figure k. Biofuel development in Ghana

Source: CIFOR (2009)

to their subjects and have complete authority over land use (with the exception of timber and mineral resources). Companies seeking large areas can therefore negotiate directly with traditional rulers; there are no requirements to include government or community members to ensure adequate participation and equitability of land deals. This enables companies to access land with few legal and bureaucratic complications.

\section{Business models}

Some of the earliest biofuel developments in Ghana were in the form of smallholder cultivation schemes. 
A joint public, private and NGO project sought to develop the biofuel sector through smallholder cultivation. The scheme unfortunately collapsed as a result of productivity, pricing, and offtake issues forcing 1096 farmers to abandon the 800 acres cultivated with jatropha plants. Since this failed experiment, investments have emphasised industrial plantation style business models. Although a number of companies are interested in supplementing plantations production with production from smallholders, no such initiatives have yet been conceived. Some companies have indicated they will wait for the successful commercialisation of jatropha before committing to smallholder participation.

Almost all the companies operating are Ghana are wholly foreign-owned or financed with foreign capital. As Ghana's investment regime incentivises exportation (through free trade zones and tax credits), investors will likely target export markets. Within Ghana there is little evidence of domestic business participation, with companies generally opting for highly vertically integrated structures.

\section{Socioeconomic impacts}

Although the scale of jatropha cultivation remains limited in Ghana, unequal benefit capture is amply evident. As land can be directly acquired from village authorities, few adversely impacted households participate in negotiations. Where these village authorities lack strong downwards accountability, many households lose land without any form of compensation or redress. At one plantation, some households lost approximately $80 \%$ of their total land holdings. This caused an array of socioeconomic problems such as reduced food security, loss of income, out-migration, and scarcity of suitable replacement land (Schoneveld et al., forthcoming). At many other plantations, similar problems are apparent. Communities are often easily swayed to relinquish their landholdings with grand, typically undocumented, promises of 'development'. Although plantations do create employment, the economic value of the jobs is expected to be lower than that of existing agricultural activities in many areas.

Further plantation expansions in Ghana can bring about serious risks. A major obstacle to sustainable biofuel development is that many plantations are being developed without government oversight. This is depriving the Government of the opportunity to assess site suitability and steer companies' social, economic, and environmental (impact mitigation) practices. While some companies have established themselves in full compliance with the various regulations (such as conducting an environmental impact analysis), many companies are operating outside the law. Companies such as Agroils/Smart Oils, Caltech Venture, Kimminic Estates and Jatropha Africa involve foreign capital and have already started cultivating under business models involving large-scale plantations (thus requiring an environmental permit), yet as of August 2009 they were not properly registered and had not obtained the necessary permits (Schoneveld et al., forthcoming).

\section{Environmental impacts}

The majority of investments are being developed in the forest transition zone. Although the vegetation density is lower than in the southern regions, it encompasses some of the largest forested areas in the country (see Figure $\mathrm{m}$ ). The region of Brong Ahafo, for instance, has the largest proportion of land classified as forests, with 52\%. Approximately $75 \%$ of this forested land has no legal protection (besides commercial timber species). Considering the intensity and scale of biofuel developments in the region, the risk of biofuel-induced deforestation is substantial. This risk is further amplified by the lack of government control and regulatory compliance of investors. A number of lands allocated to plantations (such as those of Kimminic Corporation and Scanfuel) comprise richly forested areas. Increasing land scarcity as a result of plantation development also places significant indirect pressures on forests, as has already become apparent at one plantation.

\subsection{Biofuel development in Tanzania ${ }^{30}$}

\section{Production dynamics}

Investment in biofuel feedstock cultivation commenced in 2005. It is estimated that since then approximately 4 million ha have been requested by various entities, with 640000 ha being formally allocated to date (Sulle and Nelson 2009). Although most investments are pursuing jatropha cultivation

30 Compiled by George Schoneveld, CIFOR. 


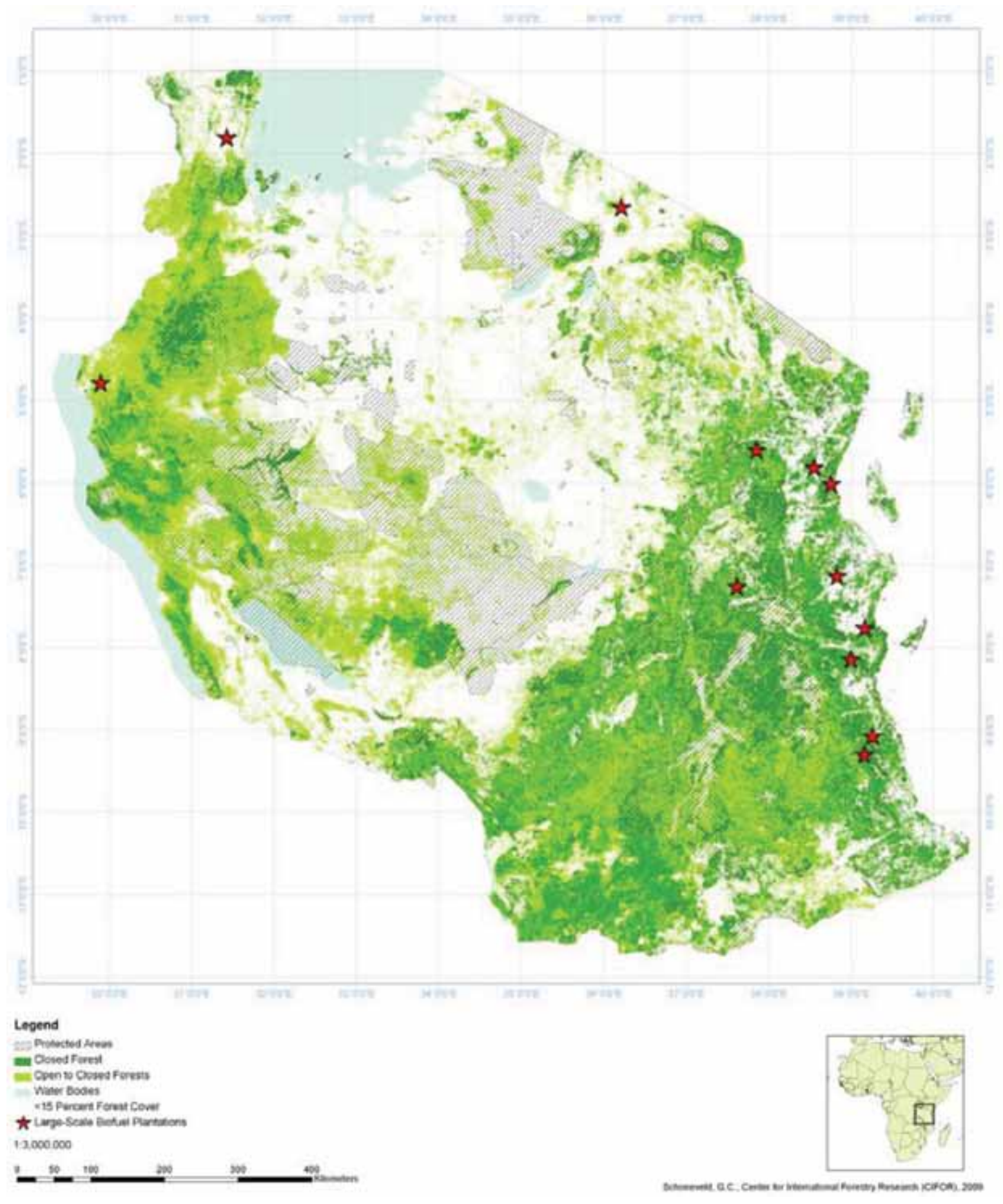

Figure I. Biofuel development in Tanzania

Source: CIFOR (2009)

on an industrial scale, a number of investors are targeting other common feedstock such as oil palm, sugarcane and sweet sorghum, but also the indigenous oil-seed bearing tree Croton megalocarpus.

Few other countries in sub-Saharan Africa experienced this intensity of interest in the biofuel sector, owing largely to Tanzania's relative political stability, availability of arable land (the Tanzania Investment Centre claims that less than one-quarter is under cultivation), relatively favourable agro-ecological conditions, and cheap production factors. Policy makers initially took a very accommodating stance towards biofuel as an 
opportunity for economic development, with many companies projecting capital outlays in excess of US\$500 million. Early studies (see GTZ 2005) and support from multilateral and bilateral institutions undoubtedly contributed significantly to this.

Although a substantial number of companies claim to be operating in Tanzania, Kasanga (2008) inventoried 37 companies and found that only a few have in fact obtained legal occupancy rights over land. This can partially be attributed to lengthy and cumbersome land acquisition processes. Only few companies have commenced large-scale cultivation activities, with activities to date typically limited to small nursery and trial sites (for the location of the biofuel companies in Tanzania, see Figure l). The commercialisation of and trade in biofuel products is consequently negligible. As official data is lacking it is difficult to estimate the area of feedstock under cultivation. It is unlikely, however, that commercial plantations collectively cultivate more than 5000 ha of land. At present, the most advanced developments have transpired through outgrower business models. The two companies that were sourcing feedstock entirely from outgrowers-Prokon, with 16800 outgrowers cultivating 9600 ha of jatropha (Loos 2009) and Diligent, with more than 5000 outgrowers cultivating 3500 ha of jatropha (Sulle and Nelson 2009)—appear to be leading the sector's development. Diligent is currently processing approximately 600-800 litres of straight jatropha oil per day (Sulle and Nelson 2009), while Prokon is expecting to commence processing in 2010. Diligent is currently also experimenting with the production of 'green charcoal' from jatropha seedcake.

In spite of early promises, opportunities in the sector have clearly not manifested for industrial business models. Increasing scepticism as to jatropha's productivity, low oil prices, bad press, and the global financial crisis have contributed significantly to a reduction in the expected expansion rate in Tanzania. One of the largest developments in Tanzania, SEKAB, which initially had ambitious plan to cultivate 400000 ha of sugarcane, has pulled out of Tanzania completely, citing financing issues. Bioshape, having acquired 81000 ha of land for jatropha cultivation in the coastal region, is rumoured to have run into similar problems. Although operational since 2006, no more than 300 ha are actually under cultivation (as of November
2009). Similarly, Biomassive acquired 55000 ha of land for jatropha cultivation in 2007, though to date its presence in Tanzania is limited merely to paperwork.

Despite ambitious plans, Tanzania's biofuel sector remains in its infancy. Following damning studies and media reports questioning the sector's sustainability, government enthusiasm has also simmered ostensibly. The Government of Tanzania has reportedly ceased further land allocations until a biofuel policy has been ratified (East African 2009). Nevertheless, as a result of considerable domestic tensions relating to sector development, it is unlikely the early investor enthusiasm will prevail. Companies such as the African Biofuels and Emission Reduction Company (ABF) have halted expansion plans due to political uncertainty, awaiting a comprehensive policy (Adamow personal communication). Although sector guidelines will likely be approved in early 2010, this will only serve as an interim measure until a comprehensive biofuel policy is developed. This is not expected before 2012 (Kiwele personal communication).

\section{Business models}

Most investments in the Tanzanian biofuel sector are championed by foreign, mostly European, enterprises. Although the most advanced endeavours are in the form of outgrower schemes without any industrial nucleus plantations, most developments are conceived as large-scale industrial monoculture estates. Also, although most companies assert their long term desire to contract smallholders, plantations development is in all cases the initial priority.

Presumably, most investors seek economies of scale in order to be cost-competitive in foreign markets. In the absence of policies that prioritise domestic offtake, most companies will target the large foreignmandate driven markets. Without smallholders integrated into the value chain, the sector will likely be characterised by a high degree of vertical integration, with few domestic business linkages.

\section{Socioeconomic impacts}

As biofuel products have not been extensively commercialised, significant benefits have not as of yet accrued along the value chain or to communities in the vicinity of large-scale plantations. Although 
the Prokon and Diligent outgrower schemes have been operational for some years already, a detailed socioeconomic impact assessment has not been performed. Both companies do, however, offer guaranteed offtake at guaranteed prices, providing some market security to smallholders.

The most significant socioeconomic concern relates to the manner in which land is acquired. Most companies obtained general (public) lands owned by the state with the mediation of government agencies (WWF 2009). However, these lands are under a de facto open access regime, implying that they often provide vital economic and subsistence services to rural communities. Due to lack of statutory rights, adversely impacted groups often have not been eligible for compensation. Although to date access has presumably not been significantly constrained, this will likely deteriorate as plantations expand. The concomitant livelihood impacts could be dire, especially since some plantations are located in relatively high population density areas (for example, close to large cities and key transportation routes), notably in the coastal areas such as Bagamoyo. Even when registered village lands are acquired, there have been instances where land is sold at exploitative rates as a result of unrealistic expectations (regarding employment and infrastructure, for instance) on behalf of the land-losing communities. Although in most cases the repercussions are not yet apparent, land loss could severely affect livelihood conditions without effective remediation mechanisms.

\section{Environmental impacts}

A WWF report (2009) has raised concerns about the risk of biofuel-induced deforestation in the region. For example, the report noted that on allocated lands in the coastal regions of Bagamoyo, Lindi and Rufiji, at least five plantations comprised high conservation value $(\mathrm{HCV})$ areas. Furthermore, some allocated lands are located on the outskirts of protected areas. This could disturb animal migration routes and contribute to anthropogenic pressures on these areas due to increasing land scarcity and decreased access to forest resources. The degree to which this will engender adverse environmental impacts in the future will depend significantly on the impact mitigation strategies of proponents. Some companies have indicated that migration corridors will be maintained and any HCV areas within the allocated lands left unexploited.

Although recent reports (WWF 2009; Sulle and Nelson 2009) assume outgrower business models will not adversely impact the environment, Loos (2009) made an important observation that $44 \%$ of the Prokon outgrowers cultivated on new land due to a reluctance to abandon food crops, which does illustrate that the deforestation risk in the case of outgrowers should not be downplayed.

\subsection{Biofuel development in Mozambique $^{31}$}

\section{Production dynamics}

Similar to Ghana and Tanzania, Mozambique has received significant interest from biofuel investors over recent years. Deininger (2009) reports that, over 18 months, Mozambique received applications for 13 million ha for biofuel production (more than onethird of its total arable land). Data on the actual scale and status of investments is, however, severely lacking and contradictory. In total 18 investors have been identified who claim to be operating in the country, 16 of which are using jatropha as a feedstock and two sugarcane (Figure m). Katerere (2009) quotes the Director of the Agricultural Promotion Centre as saying that only 83000 have in fact been allocated to biofuel investors. A report by Ribeiro and Matavel (2009), on the other hand, asserts that 183137 ha have been allocated to jatropha production, with approximately 10000 ha under cultivation. The two sugarcane for ethanol ventures claim to have access to 30000 and 23000 ha, although cultivation activities appear to be limited.

Despite this, many promising developments have run into problems. Pro-Cana, one of the first approved investors, abandoned the venture, citing poor financial performance and the global economic climate (All Africa 2009). Similarly, one of the largest established jatropha plantations owned by ESV Bio Africa was sold to two Italian energy companies following marketing and productivity issues. Other upstarts, such as EnviroTrade, C3, CHEMC Agric and Bachir Jatropha have also ceased their operations, likely as a result of the global recession and low oil prices (Setzkorn 2009; Ribeiro and Matavel 2009).

31 Compiled by George Schoneveld, CIFOR. 


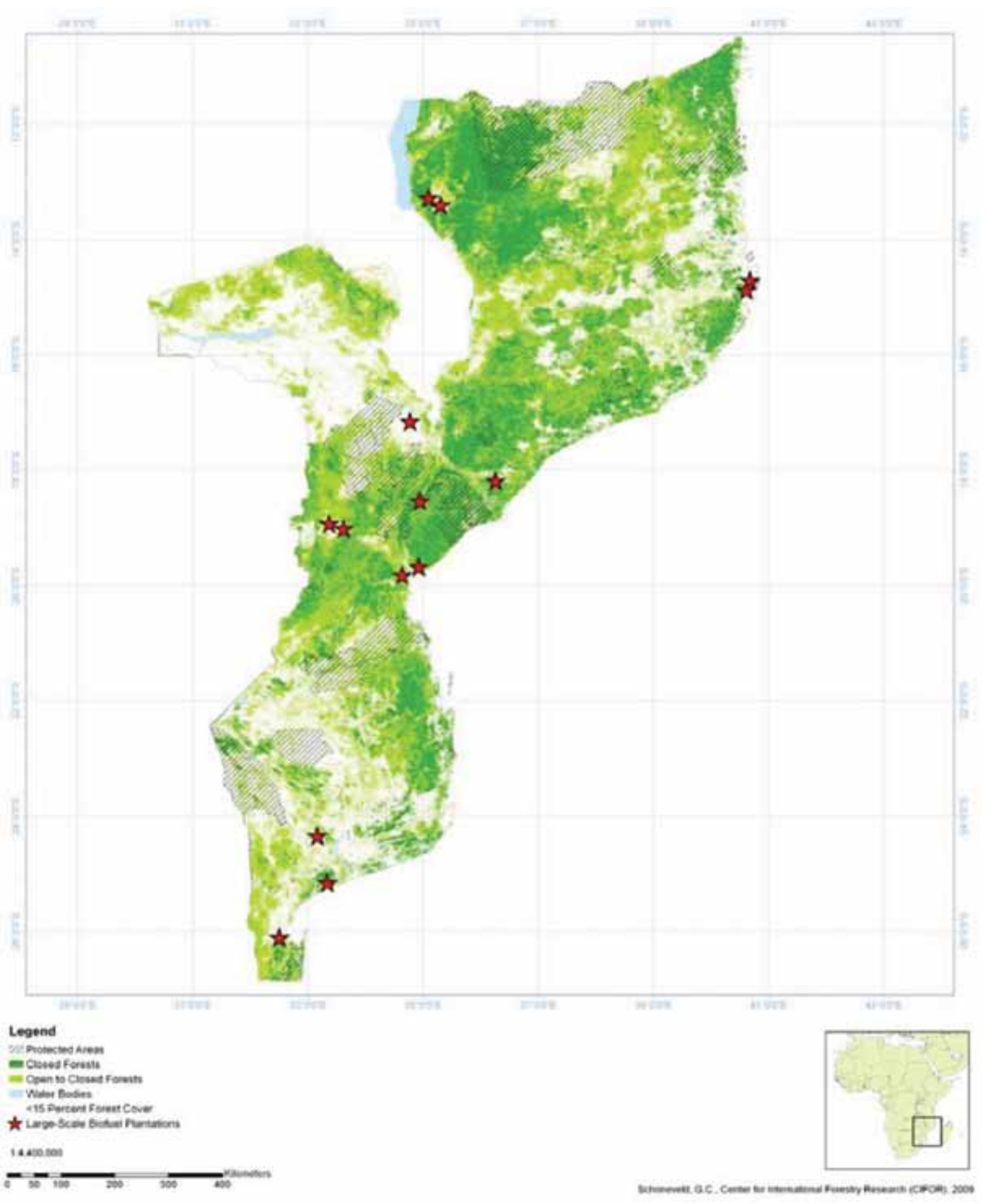

Figure $\mathrm{m}$. Biofuel development in Mozambique

Source: CIFOR (2009)

Although, as in most African countries, the anticipated benefits have far from materialised, the Government of Mozambique, notably its President, has always had high hopes for the sector. Taking Brazil's example, the Government of Mozambique saw great opportunity in capitalising on the new wave of interest in biofuels. Following a visit by the Brazilian President Luiz Lula da Silva in 2005, actively promoting biofuels as a pathway to economic growth, a Memorandum of Understanding was signed between the two countries aimed at transferring technologies and expertise 
and promoting commercialisation. In November 2009, a US\$6 billion investment accord was signed with Brazil to explore biofuels with the objective of reducing the Mozambican energy import bill and increasing foreign exchange earnings (Katerere 2009). Brazilian investors would, in turn, gain access to the markets of the European Union and the United States on more favourable terms of trade.

Mozambique is also one of the first countries in Africa to have developed a biofuel policy; illustrating its commitment to sector development. A key policy objective is to enhance the resource base for efficient energy use and reliable supply.

\section{Business models}

According to the Ministry of Agriculture (cited in Ribeiro and Matavel 2009), approximately 1000 ha of jatropha were cultivated by smallholders in 2007, attracted by high projected prices. However, many farmers abandoned the crops in the following season when yields disappointed and marketing proved more difficult than anticipated. The most dominant business model to date is the plantation model. Although numerous investors have voiced their interest in commencing outgrower schemes, none appear to be operational as of yet. Although the Mozambican biofuels policy aims to promote domestic biofuel consumption, most companies will likely target export markets in the absence of restrictions. Mozambique has also signed a bilateral agreement with China for duty and quota free export to its markets, which could over time further enhance biofuel export opportunities.

\section{Socioeconomic impacts}

No comprehensive studies have to date been published on the impact of biofuel development in Mozambique, however some media reports have raised concerns. For example, the PROCANA investment has been fraught with conflict since its inception. The land was initially allocated to people relocated from a protected area, risking the loss of important grazing grounds (Mother Jones 2009). Furthermore, there were concerns that the plantation, which would eventually require more than 400 million litres of water for irrigation, would create significant water shortages. In another case, the company Energem acquired 60000 ha from farming communities in the country's south, an area struggling with food sovereignty. Ribeiro and Matavel (2009) suggest that the land was relinquished under pressure by community leaders.

In a net food importing country such as Mozambique with $38 \%$ of the population undernourished, it is likely that the widespread conversion of agricultural land will have profound socioeconomic implications. A detailed assessment of the land use of plantations and the manner in which these lands are acquired is certainly warranted.

\section{Environmental impacts}

The largest concentrations of investment are in the southern provinces of Gaza and Inhambane and the Zambezi Delta, encompassing the provinces of Sofala, Manica, and Zambezia (Figure q). Especially in regards to the latter region, being richly forested and an important wetland area, largescale monoculture plantations could potentially have dire environmental consequences. However, no information is available to accurately assess the potential risks. 

Liquid biofuels have been produced on a commercial scale for many years, although political decisions made mainly in Europe and the United States have induced a sharp increase in demand. Furthermore, growing attention to rising greenhouse gas emissions (GHG) and global warming, combined with unstable and surging petroleum prices, are factors promoting biofuels as energy alternatives in the transportation sector. While sustainably produced biofuels have the potential to foster rural local development and to replace fossil fuels, their envisaged large scale and fast expansion has been contested on various fronts, including concerns about food security, impacts on small scale farmers, equity, increased competition for water, local pollution, and increased deforestation. The latter concern is in part related to the additional GHG emissions from forest clearing, broader concerns about the loss of natural heritage and biodiversity, and the loss of environmental and other services and goods that forests provide to local communities.

This report examines whether the recent increase in biofuel feedstock production is resulting in increased deforestation rates and magnitudes within tropical regions. It reviews several methodological challenges for undertaking this analysis, and presents a set of preliminary findings. The analysis is focused on three regions from a global perspective: Latin America, southeast Asia, and sub-Saharan Africa. The report deals only with agriculture-based feedstocks such as sugarcane, soya, palm oil and jatropha, known also as first generation biofuels, because second generation biofuels from wood or other lignocelullosic materials have not yet been produced on a commercial scale. The analysis centres on the years since 2000 due to the marked increase in biofuel production since then.

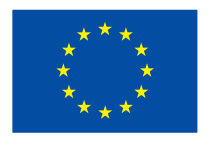
policies and practices that affect forests in developing countries. CIFOR is one of 15 centres within the Consultative Group on International Agricultural Research (CGIAR). CIFOR's headquarters are in Bogor, Indonesia. It also has offices in Asia, Africa and South America. 